UNIVERSIDADE DE SÃO PAULO

FACULDADE DE ODONTOLOGIA

\title{
AVALIAÇÃO COMPARATIVA DA CITOTOXICIDADE IN VITRO DOS SOLVENTES UTILIZADOS NO RETRATAMENTO ENDODÔNTICO
}

KAZUMI ONAGA NAGAYAMA OYAMA

Dissertação apresentada à Faculdade de Odontologia da Universidade de São Paulo, para obter o Título de Mestre, pelo Programa de Pós-Graduação em Odontologia. Área de Concentração: Endodontia.

São Paulo 2003 
UNIVERSIDADE DE SÃO PAULO

FACULDADE DE ODONTOLOGIA

\section{AVALIAÇÃO COMPARATIVA DA CITOTOXICIDADE IN VITRO DOS SOLVENTES UTILIZADOS NO RETRATAMENTO ENDODÔNTICO}

KAZUMI ONAGA NAGAYAMA OYAMA

Dissertação apresentada à Faculdade de Odontologia da Universidade de São Paulo, para obter o Título de Mestre, pelo Programa de Pós-Graduação em Odontologia. Área de Concentração: Endodontia. Orientador: Prof. Dr. Marcelo dos Santos

São Paulo 
Data da Defesa: 04/06/03

\section{Comissão Julgadora}

Prof. Dr.(a) Marcelo dos Santos

Julgamento: Aprovada Assinatura:

Prof. Dr.(a) Celso Luiz Caldeira

Julgamento:Aprovada Assinatura:

Prof. Dr.(a) Maria Luiza Morais Barreto de Chaves

Julgamento: Aprovada Assinatura: 


\section{Catalogação-na-Publicação}

Serviço de Documentação Odontológica

Faculdade de Odontologia da Universidade de São Paulo

Oyama, Kazumi Onaga Nagayama

Avaliação comparativa da citotoxicidade in vitro dos solventes utilizados no retratamento endodôntico / Kazumi Onaga Nagayama Oyama ; orientador Marcelo dos Santos. -- São Paulo, 2003.

111p. : tab., fig. ; $30 \mathrm{~cm}$.

Dissertação (Mestrado - Programa de Pós-Graduação em Odontologia. Área de Concentração: Endodontia) -- Faculdade de Odontologia da Universidade de São Paulo.

1. Endodontia - Solventes - Citotoxicidade - Avaliação comparativa 


\section{DEDICATÓRIA}

Dedico esta vitória, com muito carinho, a você Silvio, meu esposo, conselheiro e grande incentivador do meu desenvolvimento. Seu apoio foi fundamental para a minha conquista. Obrigada pela compreensão, amizade e por ter me mostrado o caminho nos momentos mais difíceis desta jornada.

Aos meus queridos pais Takeo e Yukiko Onaga por terem permitido a minha busca de conhecimentos mostrando-me que tudo é possível quando se tem dedicação e determinação.

Aos meus irmãos Hiroshi, Kiyoshi e Suemi por entenderem as minhas ausências, por incentivarem meus estudos e por compartilharem cada conquista da minha vida. Por perceberem as minhas angústias e preocupações e acima de tudo por estarem sempre presentes em todas as fases da minha caminhada pessoal, profissional e espiritual. 
Aos meus amados sobrinhos Ayumi, Rika, Mie, Tadashi, Miwa, Akemi, Takeyuki, Felipe, Takeyoshi e Tiemi um legado da minha persistência em apreender conhecimentos deixando como exemplo: que tudo é possível quando se têm objetivos na vida.

Às pessoas queridas que me alegraram pelo prazer de terem cruzado o meu caminho nesta vida. Meus sempre amigos: Adélia, Carlos Ken, Débora Coelho, D. Fátima, D. Sonia, Edson Imai, Eiji, Elza Imai, Evandro, Gisele, Hu, Jorali, Julio, Kana, Kazu, Manami, Maria Luiza, Matiko, Nori, Paulinha e Roseri ofereço a vocês o mérito deste trabalho. 
Ao Prof. Dr. Marcelo dos Santos por me oferecer a "grande oportunidade" de desenvolvimento acadêmico. Agradeço, de coração, pois mostrou-me que o sucesso, o progresso e o sabor da vitória são resultados de esforços próprios. Valeu o aprendizado, a convivência, a liberdade para buscar soluções e acima de tudo acreditar que sou merecedora daquilo que quero e desejo ser. 
À Profa. Dra. Maria Luiza Morais Barreto Chaves em me confiar a "grande oportunidade" a fim de desenvolver a minha pesquisa. Por ter me acolhido e agraciado com sua amizade e seus conhecimentos inigualáveis.

Tentar mostrar minha gratidão em palavras seria ousar por demais, contudo, não tentar, seria pecar por omissão.

Deixo para o futuro o fruto de dois anos de estudo. Muitas células foram cultivadas e sacrificadas. Foram dias e meses de laboratório. Lembro-me como se fosse hoje: você Professora Maria Luiza e sua equipe de trabalho: Marcela, Erica, Cristiane, Vanessa, Marconi, Hu, Luana, Jô, Prof. Renato, Aurolice e Rodrigo orientando e observando os meus primeiros passos no laboratório onde me fizeram sentir orgulho de poder trabalhar naquele local e assim pude empenhar-me para a finalização deste trabalho. A todos vocês que participaram, presenciaram e incentivaram cada fase deste trabalho, minha imensa gratidão. Este mérito é de todos vocês.

Ao meu amigo, Prof. Evandro Luiz Siqueira, meu eterno voto de gratidão pela oportunidade de condecorar-me com a sua confiança, amizade e sinceridade. Tudo isto é fruto do teu semeio e de ter acreditado no meu trabalho. 


\section{AGRADECIMENTOS}

Ao Prof. Dr. João Humberto Antoniazzi, grande e iluminado ser em sabedoria, humildade e bondade. Agradeço a doação de seus ensinamentos, a paciência e a oportunidade em seu convívio.

Ao Prof. Dr. Antonio Carlos Bombana pelo carinho, pelo sorriso amigo, pela disposição e orientação nos corredores da disciplina, pela oportunidade de estágio em Endodontia no Curso de Reabilitação Oral. Minha enorme gratidão.

Ao Prof. Dr. Matsuyoshi Mori pela enorme oportunidade de estágio em Endodontia em seu curso de Reabilitação Oral, pela amizade e incentivo nesta minha jornada. Meu muito obrigado.

Ao Prof. Dr. Manuel Eduardo de Lima Machado pela oportunidade em acompanhar as atividades didáticas em Endodontia do curso noturno da FOUSP, minha gratidão. 
Ao Prof. Dr. Celso Luiz Caldeira e æ̀s Profas. Dras. Manoela Domingues Martins e Márcia Martins Marques pelas preciosas sugestões e comentários melhorando o nível deste trabalho, meus agradecimentos.

Aos Professores da Disciplina de Endodontia: Prof. Dr. Giulio Gavini, Prf. Dr. José Luiz Lage-Marques, Prof. Dr. Abílio Albuquerque M. de Moura, Prof. Dr. Igor Prokopowitsck pela doação de seus conhecimentos durante todo o curso de mestrado.

À Ana Maria e Neuza pela paciência com que trataram e solucionaram as atividades de secretaria, mantendo me informada sobre todas as documentações necessárias durante o meu cumprimento de créditos deste curso. Aos Srs. Aldo e Luizinho pela prestação de serviços durante a confecção do material didático; à vocês meu carinho, minha gratidão.

Aos meus colegas e amigos de turma: Alexandre, Ana Lucia, Ângela, Calil, Cristiane, Daniel, Eduardo, Emerson, Luciano, Miguel, Reinaldo, Ricardo, Sonia e Vera pelo convívio, partilha de conhecimentos e incentivos para que o meu aprendizado e o trabalho de conclusão pudessem ser concretizados.

À Profa. Dra. Claudimara Lotfi pela doação de células congeladas NIH 3T3 para que o trabalho pudesse ser concretizado. Minha gratidão. 
Aos meus amigos de consultório: Edison Haruki Tango, Fabio Trevisan, Sandra Yamazaki, Márcia Kamimura, Hu Li Yen, Marcelo Sado e Américo Kurita por estimularem meus estudos e por entenderem as minhas ausências. Compartilho esta vitória com vocês.

Aos meus amigos e colegas de trabalho que permitiram, apoiaram e orientaram a minha atividade didática: Prof. Dr. Marcelo dos Santos, Profa. Dra. Flor Luigina V. Santos, Profa. Patrícia Ferrari, Prof. Evandro Luiz Siqueira, Profa. Cristiane da Costa, Ana, Jussara, Rogério, Patrícia Hazoff e Rocio. Meu reconhecimento.

À Luzia, Cidinha e Solange pelos serviços prestados nas correções de referências bibliográficas, formatação do texto e realização de ficha catalográfica. À Rosana pela revisão e orientação na confecção de tabelas e gráficos. Meu muito obrigado.

À Profa. Jorali, minha amiga, meu reconhecimento pela doação de seus conhecimentos em língua portuguesa para que este trabalho pudesse ser concretizado.

À querida amiga Hu pela orientação e realização de análise estatística e aos amigos Carlos Ken e Sérgio pelo auxílio nas fotografias e impressão do texto. Muitíssimo obrigado. 


\section{SUMÁRIO}

p.

LISTA DE FIGURAS

LISTA DE TABELAS

LISTA DE ABREVIATURAS E SIGLAS

LISTA DE SÍMBOLOS

RESUMO

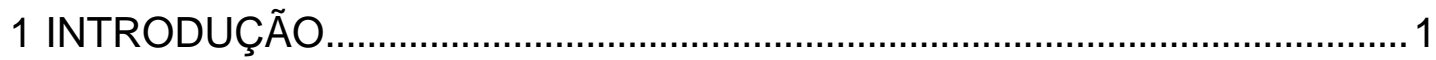

2 REVISÃO DA LITERATURA .............................................................. 4

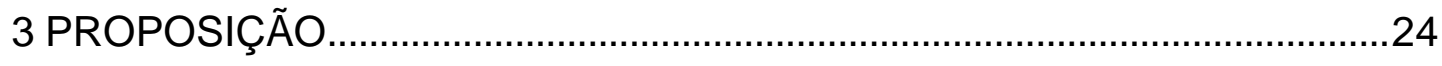

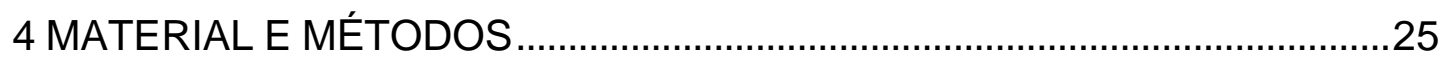

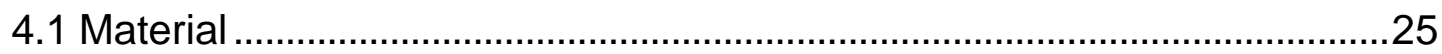

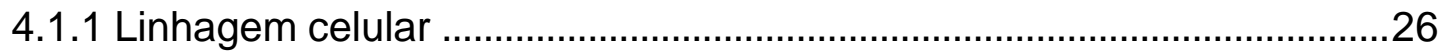

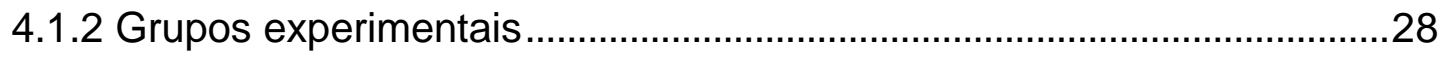

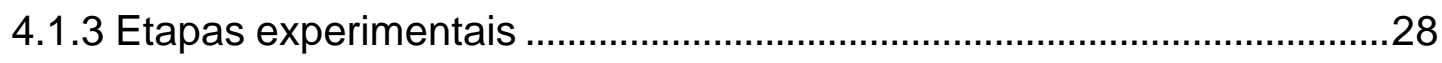

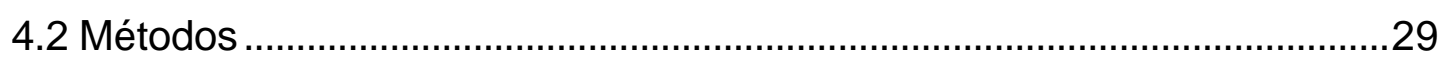

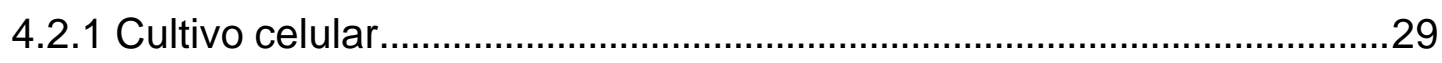

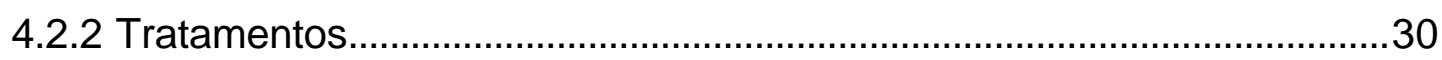

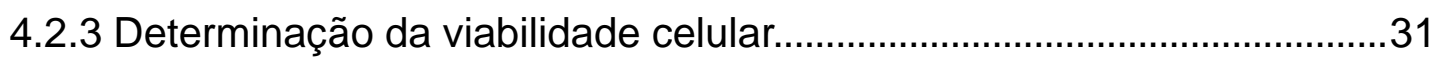

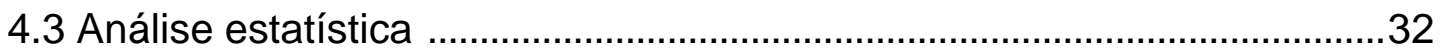

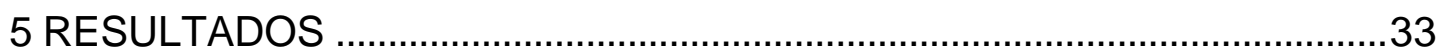


6 DISCUSSÃO

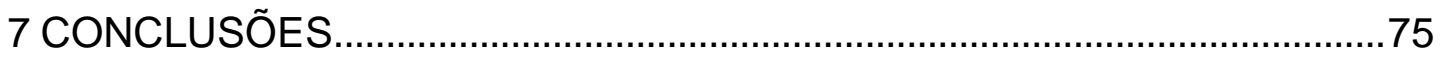

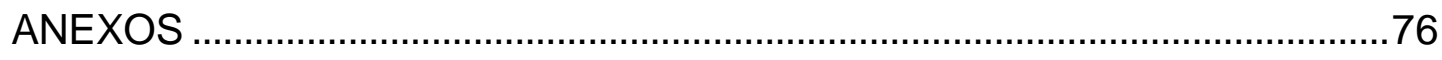

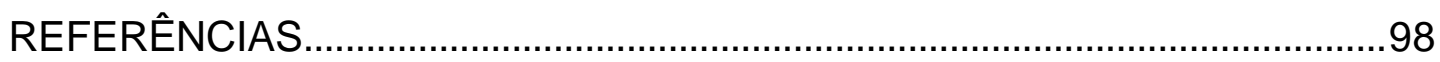

SUMMARY 


\section{LISTA DE FIGURAS}

Figura 4.1 - Fotomicrografia de cultura de células de fibroblastos NIH 3T3, com filtro verde (aumento de 100X).

Figura 4.2 - Fotomicrografia de cultura de células de fibroblastos NIH 3T3, sem filtro verde (aumento de 100X).

Figura 4.3 - Área interna do fluxo laminar para o cultivo celular 30

Figura 4.4 - Fotomicrografia da câmara de Neubauer, somente as células em morte celular se apresentam coradas em azul e com limites irregulares. As demais se apresentam arredondadas, transparentes, com a membrana refringente e com limites nítidos (aumento de 200X) 32

Figura 5.1 - Viabilidade celular quando da exposição aos solventes em diferentes concentrações para o período de 5 minutos. A concentração $0 \%$ corresponde ao grupo controle com número de células no momento do tratamento 36 
Figura 5.2 - Gráfico com as curvas dos valores correspondentes a porcentagem das células viáveis após a exposição de 5 minutos nas diferentes concentrações dos solventes estudados

Figura 5.3 - Viabilidade celular quando da exposição aos solventes nas concentrações de 0,10 e $25 \%$ para o período de 10 minutos. A concentração $0 \%$ corresponde ao grupo controle com número de células no momento do tratamento

Figura 5.4- Gráfico com as curvas dos valores correspondentes a porcentagem das células viáveis após a exposição de 10 minutos nas concentrações de 0,10 e $25 \%$ dos solventes estudados .42

Figura 5.5 - Viabilidade celular quando da exposição aos solventes nas concentrações de 0,10 e $25 \%$ para o período de 15 minutos. A concentração $0 \%$ corresponde ao grupo controle com número de células no momento do tratamento .46

Figura 5.6- Gráfico com as curvas dos valores correspondentes a porcentagem das células viáveis após a exposição de 15 minutos nas concentrações de 0,10 e $25 \%$ dos solventes estudados .47 
Figura 5.7 - Viabilidade celular quando da exposição direta ou indireta dos solventes sobre as células em cultura, nas concentrações de 0 , 5 e $10 \%$ no período de 5 minutos. A concentração 0\% corresponde ao grupo controle com número de células no momento do tratamento .52

Figura 5.8- Gráfico com as curvas dos valores correspondentes a porcentagem das células viáveis após a exposição de 5 minutos nas concentrações de 0,5 e $10 \%$ dos solventes estudados em contato direto e indireto .53

Figura 5.9- Gráfico que representa os valores da média \pm desvio padrão do número de células viáveis dos solventes testados na concentração de $5 \%$ para o período de 5 minutos, os solventes foram previamente solubilizados em álcool absoluto 58 


\section{LISTA DE TABELAS}

Tabela 5.1 - Valores da média \pm desvio padrão correspondentes ao número de células viáveis $\left(\mathrm{X} 10^{4}\right)$ quando da exposição aos solventes testados em diferentes concentrações para o período de 5 minutos. $\mathrm{n}=$ número de poços com células, utilizados para 0 tratamento 34

Tabela 5.2 - Teste de comparação múltipla Tukey-Kramer, período de 5 minutos e concentração de $5 \%$ .38

Tabela 5.3 - Teste de comparação múltipla Tukey-Kramer, período de 5 minutos e concentração de $10 \%$ 38

Tabela 5.4 - Teste de comparação múltipla Tukey-Kramer, período de 5 minutos e concentração de $25 \%$ 39 
Tabela 5.5 - Valores da média \pm desvio padrão correspondentes ao número de células viáveis $\left(\mathrm{X}_{10}^{4}\right)$ quando da exposição aos solventes testados, nas concentrações de 0, 10 e $25 \%$ para o período de 10 minutos. $n=$ número de poços com células, utilizados para o tratamento .40

Tabela 5.6 - Teste de comparação múltipla Tukey-Kramer, período de 10 minutos e concentração de $10 \%$

Tabela 5.7 - Teste de comparação múltipla Tukey-Kramer, período de 10 minutos e concentração de $25 \%$ .43

Tabela 5.8 - Valores da média \pm desvio padrão correspondentes ao número de células viáveis $\left(\mathrm{X} 10^{4}\right)$ quando da exposição aos solventes, nas concentrações de 0,10 e $25 \%$ para o período de 15 minutos. $\mathrm{n}=$ número de poços com células, utilizados para o tratamento 44

Tabela 5.9 - Teste de comparação múltipla Tukey-Kramer, período de 15 minutos e concentração de $10 \%$ .48

Tabela 5.10 - Teste de comparação múltipla Tukey-Kramer, período de 15 minutos e concentração de $25 \%$ 
Tabela 5.11 - Valores da média \pm desvio padrão correspondentes ao número de células viáveis $\left(\mathrm{X} 10^{4}\right)$ quando da exposição aos solventes, analisados em formas de contato direto e indireto, nas concentrações de 0,5 e $10 \%$ para o período de 5 minutos. $n=$ número de poços com células, utilizados para o tratamento....49

Tabela 5.12 - Teste de comparação múltipla Tukey-Kramer, período de 5 minutos e concentração de $5 \%$. Formas de contato direto ou indireto sobre as células em cultura 54

Tabela 5.13 - Teste de comparação múltipla Tukey-Kramer, período de 5 minutos e concentração de $10 \%$. Formas de contato direto ou indireto sobre as células em cultura .55

Tabela 5.14 - Valores da média \pm desvio padrão correspondentes ao número de células viáveis $\left(\mathrm{X} 10^{4}\right)$ quando da exposição aos solventes, na concentração de $5 \%$ para o período de 5 minutos, os solventes foram previamente solubilizados em álcool absoluto. $\mathrm{n}=$ número de poços com células, utilizados para o tratamento. O controle corresponde ao grupo com a mesma proporção de álcool absoluto utilizado para solubilizar os solventes .57 
Tabela 5.15 - Teste de comparação múltipla Tukey-Kramer, período de 5 minutos e concentração de $5 \%$, solventes previamente solubilizados em álcool absoluto .59

Tabela 5.16 - Percentual de número de células viáveis quando da exposição aos solventes testados, em diferentes etapas experimentais, na concentração de $5 \%$ para o período de 5 minutos 60

Tabela AnA1 - Valores originais do número de células viáveis $\left(\mathrm{X} 10^{4}\right)$ no experimento com concentrações de 0, 5, 10, 25, 50 e 100\% do solvente óleo de laranja para o tempo de 5 minutos .77

Tabela AnA2 - Valores originais do número de células viáveis $\left(X 10^{4}\right)$ no experimento com concentrações de $0,5,10,25,50$ e $100 \%$ do solvente eucaliptol para o tempo de 5 minutos .78

Tabela AnA3 - Valores originais do número de células viáveis $\left(X 10^{4}\right)$ no experimento com concentrações de $0,5,10,25,50$ e $100 \%$ do solvente xilol para o tempo de 5 minutos 79

Tabela AnA4 - Valores originais do número de células viáveis $\left(X 10^{4}\right)$ no experimento com concentrações de 0, 5, 10, 25, 50 e 100\% do solvente clorofórmio para o tempo de 5 minutos .80 
Tabela AnA5 - Valores originais do número de células viáveis $\left(\mathrm{X} 10^{4}\right)$ no experimento com concentrações de 0, 5, 10, 25, 50 e 100\% do solvente halotano para o tempo de 5 minutos .81

Tabela AnB1 - Valores originais do número de células viáveis $\left(\mathrm{X} 10^{4}\right)$ no experimento com concentrações de 0,10 e $25 \%$ do solvente óleo de laranja para o tempo de 10 minutos .82

Tabela AnB2 - Valores originais do número de células viáveis $\left(\mathrm{X}^{4} 0^{4}\right)$ no experimento com concentrações de $0,10,25 \%$ do solvente eucaliptol para o tempo de 10 minutos .83

Tabela AnB3 - Valores originais do número de células viáveis $\left(X 10^{4}\right)$ no experimento com concentrações de $0,10,25 \%$ do solvente xilol para o tempo de 10 minutos .84

Tabela AnB4 - Valores originais do número de células viáveis $\left(X 10^{4}\right)$ no experimento com concentrações de $0,10,25 \%$ do solvente clorofórmio para o tempo de 10 minutos .85

Tabela AnB5 - Valores originais do número de células viáveis $\left(X 10^{4}\right)$ no experimento com concentrações de $0,10,25 \%$ do solvente halotano para o tempo de 10 minutos .86 
Tabela AnB6 - Valores originais do número de células viáveis $\left(\mathrm{X} 10^{4}\right)$ no experimento com concentrações de $0,10,25 \%$ do solvente óleo de laranja para o tempo de 15 minutos

Tabela AnB7 - Valores originais do número de células viáveis $\left(X 10^{4}\right)$ no experimento com concentrações de $0,10,25 \%$ do solvente eucaliptol para o tempo de 15 minutos .88

Tabela AnB8 - Valores originais do número de células viáveis $\left(X 10^{4}\right)$ no experimento com concentrações de $0,10,25 \%$ do solvente xilol para o tempo de 15 minutos .89

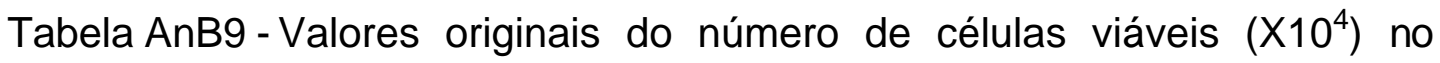
experimento com concentrações de $0,10,25 \%$ do solvente clorofórmio para o tempo de 15 minutos .90

Tabela AnB10 - Valores originais do número de células viáveis $\left(X 10^{4}\right)$ no experimento com concentrações de $0,10,25 \%$ do solvente halotano para o tempo de 15 minutos 91 


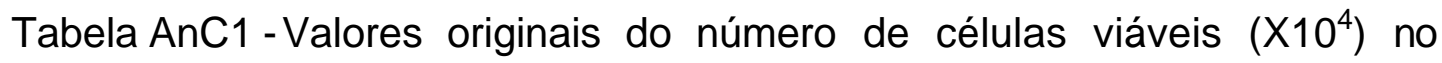
experimento com concentrações de 0,5 e $10 \%$ do solvente óleo de laranja para o tempo de 5 minutos. Solvente em contato direto com as células de fibroblastos com auxilio de lamínula de vidro e solvente vertido sobre o DMEM .92

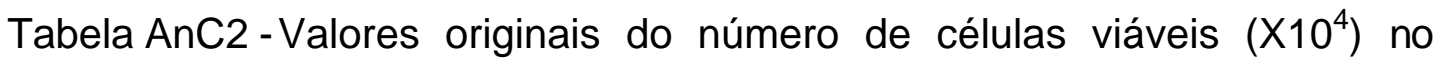
experimento com concentrações de 0,5 e $10 \%$ do solvente eucaliptol para o tempo de 5 minutos. Solvente em contato direto com as células de fibroblastos com auxilio de lamínula de vidro e solvente vertido sobre o DMEM .93

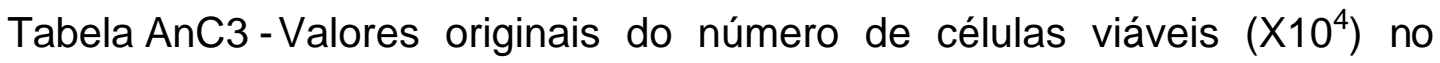
experimento com concentrações de 0,5 e $10 \%$ do solvente xilol para o tempo de 5 minutos. Solvente em contato direto com as células de fibroblastos com auxilio de lamínula de vidro e solvente vertido sobre o DMEM 94

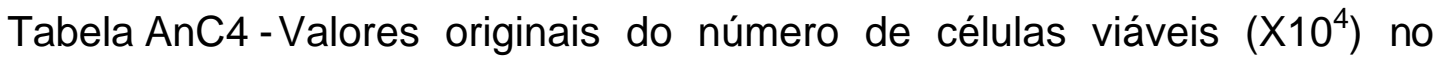
experimento com concentrações de 0,5 e $10 \%$ do solvente clorofórmio para o tempo de 5 minutos. Solvente em contato direto com as células de fibroblastos com auxilio de lamínula de vidro e solvente vertido sobre o DMEM .95 
Tabela AnC5 - Valores originais do número de células viáveis $\left(\mathrm{X}^{1} 0^{4}\right)$ no experimento com concentrações de 0,5 e $10 \%$ do solvente halotano para o tempo de 5 minutos. Solvente em contato direto com as células de fibroblastos com auxilio de lamínula de vidro e solvente vertido sobre o DMEM .96

Tabela AnD - Valores originais do número de células viáveis $\left(X 10^{4}\right)$ no experimento com concentrações de $5 \%$ dos solventes estudados para o tempo de 5 minutos. Solventes foram solubilizados previamente em álcool absoluto 97 


\section{LISTA DE ABREVIATURAS E SIGLAS}

\begin{tabular}{ll} 
cm & Centímetros \\
$d$ & contato direto \\
in & contato indireto \\
DMEM & Meio de cultura Eagle modificado por Dulbecco \\
DMSO & Di-metil Sulfóxido \\
FBS & Soro fetal bovino \\
mL & Mililitros \\
NIH & "National Institute of Health" \\
ns & não significante \\
PBS & Solução Balanceada de Fosfato \\
pH & Potencial hidrogeniônico \\
P/S & Penicilina/Estreptomicina \\
$\mu L$ & Microlitros \\
$\mathrm{p}$ & probabilidade \\
$\mathrm{s}$ & significante \\
\hline
\end{tabular}




\section{LISTA DE SÍMBOLOS}

$\begin{array}{ll}\mathrm{n} & \text { tamanho da amostra } \\ \% & \text { sinal matemático que indica porcentagem } \\ & \text { sinal matemático que indica menor ou igual } \\ \circ \mathrm{C} & \text { graus centígrado } \\ \mathrm{CO}_{2} & \text { dióxido de carbono }\end{array}$




\section{RESUMO}

\section{AVALIAÇÃO COMPARATIVA DA CITOTOXICIDADE IN VITRODOS SOLVENTES UTILIZADOS NO RETRATAMENTO ENDODÔNTICO}

O objetivo deste estudo foi comparar a citotoxicidade in vitro dos solventes utilizados em terapia de retratamento endodôntico: óleo de casca de laranja, eucaliptol, xilol, clorofórmio e halotano através da avaliação da citotoxicidade de cada solvente em diferentes concentrações finais e condições de contato com as células de fibroblastos de linhagem NIH 3T3. O experimento foi dividido em 4 etapas: etapa 1 - os solventes foram misturados em meio de cultura (DMEM) nas concentrações finais de 0, 5, 10, 25, 50 e 100\% e depositados sobre a cultura de células para o tempo de 5 minutos; etapa 2os solventes foram misturados em meio de cultura nas concentrações finais de 0,10 e $25 \%$ e depositados sobre a cultura de células para os tempos de 10 e 15 minutos; etapa 3a- os solventes foram depositados sobre as células de fibroblastos (contato direto) e acrescido de meio de cultura; etapa 3bonde os fibroblastos receberam o meio de cultura e sobre este depositado os solventes testes (contato indireto) nas concentrações finais de 0, 5 e 10\% para o tempo de 5 minutos; etapa 4- os solventes foram previamente solubilizados com o álcool absoluto na proporção de 1:1 e depois misturados 
ao meio de cultura na concentração final de $5 \%$ para o tempo de 5 minutos. A avaliação foi realizada pela contagem celular através de método de exclusão de células coradas pelo azul Trypan. Os resultados obtidos nos permitiram concluir que todos os solventes testados são citotóxicos in vitro, sendo que o óleo de laranja foi o menos tóxico, ao permitir alguma viabilidade celular. Observou-se ainda que o preparo prévio dos solventes influenciou no percentual de células viáveis. 


\section{INTRODUÇÃO}

O tratamento endodôntico busca a eliminação de microrganismos do sistema de canais radiculares e posterior obturação de modo a garantir a integridade dos tecidos periapicais. A terapia endodôntica convencional é eficaz em aproximadamente $90 \%$ dos casos; porém, por motivos diversos, a vantagem dos microrganismos æ̀s resistências orgânicas observadas pela lesão periapical decorrente de sua disseminação e invasão no periápice, em conjunto com a resposta sintomatológica, após tratamento endodôntico, caracterizam os primeiros vestígios de fracasso endodôntico e o retratamento torna-se necessário.

Uma vez determinado o insucesso endodôntico recorre-se ao retratamento conservador como a primeira alternativa escolhida pelos clínicos.

O retratamento endodôntico consiste na remoção do material existente dentro do conduto radicular, composto geralmente de um cimento obturador e um material semi-sólido, a guta-percha, seguida da reinstrumentação do canal e re-obturação. Normalmente é um procedimento tedioso e que consome muito tempo do profissional. 
Diversas técnicas são sugeridas, para proporcionar a rapidez, a eficiência e a praticidade na manobra de desobturação. Exemplos: a utilização de instrumentos aquecidos, aparelhos ultrasônicos, uso de brocas Gates-Glidden e para todas essas técnicas o uso de um solvente parece ser extremamente válido como coadjuvante na remoção da guta percha.

O solvente orgânico atua sobre a guta percha promovendo solubilização, facilitando assim a remoção do material obturador. Dentre os solventes mais utilizados para essa finalidade podemos citar o clorofórmio e o eucaliptol, amplamente utilizados desde 1850. O primeiro é considerado muito eficaz, porém, de utilização bastante questionada, devido à necessidade de reposição constante. Por alguns anos o uso do clorofórmio esteve banido em seres humanos, por ser considerado uma substância citotóxica e com potencial carcinogênico. O segundo por sua vez, apesar de apresentar menores efeitos deletérios, parece não ser eficaz ao seu objetivo (Zakariasen et al., 1990).

Outro solvente muito utilizado pelos profissionais é o xilol. Este, embora bastante eficaz, parece exercer alguns efeitos indesejáveis aos tecidos, como, por exemplo: irritação na mucosa por contato e por inalação ou ainda causar discrasias sanguíneas, convulsão, insônia, excitação e depressão do Sistema Nervoso Central, podendo levar à morte por depressão respiratória (Pécora et al., 1993).

A avaliação da biocompatibilidade dessas substâncias é de extrema importância, uma vez que essas são aplicadas no interior do canal radicular e, desta forma, podem eventualmente atingir a região apical e apresentar um 
possível efeito lesivo sobre as células vivas dessa região. A utilização de testes, in vitro, por meio de ensaios de viabilidade celular, constitui o primeiro passo para a avaliação da compatibilidade biológica de uma substância e pode fornecer elementos importantes para a análise da biocompatibilidade dos diferentes materiais.

Tentando minimizar a divergência entre a efetividade e a toxicidade dos solventes, algumas substâncias alternativas, como o halotano e o óleo de laranja, têm sido sugeridas ultimamente, o primeiro, um anestésico utilizado por inalação e o segundo usado em farmacologia para aromatizar e dar sabor. Ambos apresentando eficácia na solubilização de guta percha. Entretanto, não existem relatos quanto à sua toxicidade ou outras características relacionadas àcitotoxicidade.

Diante do conhecimento atual sobre as toxicidades dos solventes de guta percha, sabe-se que os mais eficientes, como o clorofórmio e xilol, são os mais tóxicos. Cabe assim a busca continuada de uma solução ou produto capaz de solubilizar satisfatoriamente a mesma, minimizando seus efeitos indesejáveis. Por essa razão esse estudo buscou analisar a citotoxicidade de diversas substâncias utilizadas na clínica endodôntica com o objetivo de solubilizar a guta-percha. 


\section{REVISÃO DA LITERATURA}

De acordo com Paiva \& Antoniazzi (1988), o objetivo da terapia endodôntica é todo dirigido no sentido de se obter processo reparativo no menor intervalo de tempo após a intervenção praticada e que tenha seu fecho de forma normal, como se com ele nada tivesse acontecido e assim permitindo ao dente o retorno às suas tarefas específicas.

O sucesso do tratamento endodôntico é apreciado pelas informações obtidas através de exames clínicos acrescidos da análise da imagem radiográfica. Porém, cabe ao dentista a compreensão dos fundamentos gerais do processo reparador para permitir, através da correlação com os achados clínico-radiográficos, ajuizar-se sobre o bom e mau êxito do tratamento realizado e adotar medidas conseqüentes àsuperação de falhas e dificuldades ligadas àprática endodôntica (Paiva \& Antoniazzi, 1988).

Diante do exposto, é uma tendência atual, tanto dos clínicos como dos pesquisadores, manterem a preocupação em acompanhar e estabelecer os níveis de sucesso alcançado em intervenções endodônticas realizadas, mesmo porque, esses dados poderão conduzir ao aprimoramento de novas propostas técnicas e terapêuticas. 
Como pudemos rever na literatura, há quase meio século existe uma preocupação em controlar o tratamento endodôntico realizado. O clássico estudo realizado por Ingle, em 1962, mostrou o controle de 2 anos em 1229 tratamentos endodônticos realizados, chegando ao índice de $94.45 \%$ tidos como bem sucedidos e relatando que $63.46 \%$ dos fracassos estavam relacionados com a obturação do canal.

Mais tarde, Healing \& Tamshe (1970) obtiveram 30\% insucesso de dos tratamentos endodônticos realizados em 213 dentes de pacientes que procuraram atendimento na Escola de Medicina Dentária de Jerusalém, no período de 5 anos.

Kerekes \& Tronstad (1979) realizaram controle clínico radiográfico dos 501 canais tratados pelos estudantes da Universidade de Oslo e relataram o índice de insucesso de 5\%. Os resultados mostraram ainda que $61 \%$ do insucesso estavam relacionados com a falha de obturação com selamento apical inadequado.

Barbakow et al. (1980) estudaram 566 casos de canais radiculares tratados e obtiveram um índice de $12.6 \%$ de insucesso nos 555 canais obturados. Os autores alertaram que a taxa de insucesso foi ainda maior quando o limite da obturação foi inadequado.

Desta forma argüimos que a precaução no tratamento deve ser ponto fundamental para o êxito da terapia endodôntica. Se o retratamento for inevitável, vale ressaltar que é através de um estudo criterioso da situação clínica como um todo, que se definirá como e quando se fará a nova intervenção, quer seja a cirúrgica ou de retratamento convencional. O desejo 
principal da reintervenção é ganhar acesso ao comprimento ideal de trabalho do canal radicular (Friedman \& Stabholz, 1986; Stabholz \& Friedman, 1988).

Preocupados com a grande ocorrência de casos de retratamento endodôntico em prática clínica e pouca abordagem desse assunto na literatura, alguns pesquisadores propuseram discutir os critérios para a seleção de caso e guias de plano de tratamento para retratamento endodôntico.

A persistência de sintomatologia pós-tratamento, como: sensibilidade à percussão, à temperatura e a presença de sinais clínicos da doença periapical como fístula, defeito periodontal e sinais radiográficos seriam fatores relacionados ao diagnóstico que após obtenção de informações das prováveis causas, facilitariam o traçado do plano de tratamento. E o profissional deveria alcançar um balanço para decidir qual seria a escolha de tratamento, evitando falhas desnecessárias devido à escolha errada na seleção do caso, ainda avaliar se existe cooperação do paciente e como está a habilidade profissional (Friedmann \& Stabholtz, 1986; Stabholtz \& Friedmann, 1988; Lovdahl, 1992).

Apesar de não ser o objetivo do trabalho, avaliar técnicas ou procedimentos cirúrgicos, é importante salientar que a cirurgia apical tem atuado com eficiência para a resolução dos insucessos endodônticos. Todavia, Luebke et al. (1964) advertiram haver uso abusivo desta prática que deveria ser reservada somente a casos especiais onde o retratamento for considerado de alto risco ou até impossível de ser realizado. 
Quanto æ̀s manobras de desobturação, vimos que as técnicas de remoção de guta percha incluem o uso de instrumentos manuais, instrumentos aquecidos, sistemas rotatórios, aparelhos de ultra-som e solventes (Taintor et al., 1983; Wilcox et al., 1987; Stabholz \& Friedman, 1988; Friedman et al., 1990; Teplitsky et al., 1992; Imura et al., 1996; Ferreira et al., 2001). Em muitos casos, o uso combinado de diferentes técnicas pode ser o mais eficiente método de economizar tempo (Wilcox et al., 1987; Aun \& Santos, 1989; Teplitsky et al., 1992; Imura et al., 1996; Gutmann et al., 1997; Ferreira et al., 2001; Betti \& Bramante, 2001). Mas, a remoção em muitos casos é operação tediosa e consome tempo, especificamente em canais estreitos e curvos ou quando o material obturador está bem condensado.

Com desenvolvimento de novas gerações de instrumentos, vários relatos foram descritos confirmando as vantagens de instrumento em sistema rotatório de níquel-titânio, incluindo a manutenção da forma de canal sem formação de degrau ou zip e com preparo relativamente mais rápido com aparelhos rotatórios quando comparados às limas manuais.

Zakariasen et al., em 1990, propuseram técnica de retratamento endodôntico eliminando a necessidade de clorofórmio como solvente de guta percha. Esta técnica constituía-se de um aquecimento do instrumento calcador elétrico de guta percha e solvente eucaliptol aquecido em conjunto ou isoladamente. Em adição, o ultra-som e as brocas Gattes-Glidden foram sugeridos como complementares úteis à limpeza do canal durante o re- 
preparo do sistema de canais radiculares. Observaram que o eucaliptol quando aquecido tornava-se bastante eficaz.

Lu, em 1994, descreveu um método alternativo para a remoção de guta-percha em retratamento endodôntico, utilizando solvente halotano previamente ao emprego de um aparelho de sistema de obturação termoplastificada e afirmou ser uma técnica simples e que consumiu menos tempo que outros métodos comumente empregados.

Imura et al. (1996) verificaram a eficiência de remoção de guta percha utilizando canal Finder e instrumentação manual acrescido de solvente e observaram que a combinação da técnica conseguiu remover melhor o material obturador.

Hülsmann \& Stotz, em 1997, avaliaram a capacidade de limpeza, eficácia e segurança de diferentes aparelhos para a remoção de guta percha em retratamento. Os autores observaram que houve redução de tempo quando foi associado lima tipo Hedstrom e solvente, apesar de aparelhos rotatórios terem demonstrado serem mais rápidos, a limpeza e a segurança do retratamento de canal foi melhor com instrumentos manuais em conjunto com solvente.

Ferreira et al., em 2001, demonstraram a eficiência de remoção de guta percha comparando o sistema Profiles, limas flexofiles com clorofórmio, limas Hedstrom com clorofórmio e os resultados mostraram que o uso de solvente melhorou a eficiência de limpeza.

Betti \& Bramante, em 2001, compararam Sistema Quantec SC e limas manuais com solvente quanto à eficiência de remoção de guta percha e o 
tempo despendido durante o retratamento. Os resultados mostraram que o tempo consumido foi significantemente menor com Quantec SC. Quanto à eficiência de limpeza na parede do canal, as limas manuais com solvente apresentaram-se superiores. Os autores sugeriram a combinação de instrumentos rotatórios e limas manuais com solventes durante a desobturação do canal em procedimentos de retratamento endodôntico.

Com o intuito de prevenir injúria ao tecido periapical, autores relataram que a utilização de solventes deveria ser evitada na porção apical do canal radicular (Taintor et al., 1983; Gilbert \& Rice, 1987; Gutmann et al., 1997). No entanto, a possibilidade de fratura de instrumento é a maior consideração a ser realizada, pois temos visto, clinicamente, fratura de instrumentos sem serem recuperados.

Diante da possibilidade de acidente no elemento dental durante 0 procedimento de retratamento endodôntico é prudente que nos milímetros apicais, especialmente em canais curvos, canais com material obturador bem condensado e antigo, o solvente possa ser utilizado para dissolver a guta-percha e o cimento obturador e assim diminuir os riscos de acidentes.

Muitos autores relatam a utilização de algum solvente de guta-percha, no procedimento de retratamento. Por isso, neste momento iremos enfocar sobre a efetividade de alguns solventes.

Della Nina et al. (1980) avaliaram a capacidade de solvência de eucaliptol, xilol, éter, clorofórmio, benzina, terebentina e acetona através da perda de peso dos cones de guta-percha, submetido à ação desses solventes nos períodos de 2, 10 e 30 minutos. Os autores concluíram que 
dentre os solventes estudados o que mostrou maior capacidade solvente foi o xilol, sendo que após trinta minutos a guta-percha ficou tão amolecida que impediu a continuação do processo de avaliação.

Tamse et al., em 1986, descreveram um método para comparar os solventes de guta percha e demonstraram que existem alterações de solubilização em diferentes marcas comerciais de guta percha, provavelmente devido à variação em sua composição, na quantidade de resina e cera. Os resultados mostraram que a guta percha DMS apresentou maior solubilidade que as outras marcas e o clorofórmio foi o solvente mais eficaz quando comparado ao xilol, endosolv E e óleo essencial de laranja. O endosolv E e o óleo essencial de laranja possuíram atividade solvente somente em algumas marcas comerciais de guta-percha. Os autores enfatizaram a necessidade de avaliar várias marcas comerciais de guta percha quando da realização de testes de solubilização utilizando solventes orgânicos.

Wennberg \& Orstavik (1989) avaliaram a capacidade de alguns solventes em dissolver os cones de guta-percha. O xilol e eucaliptol foram comparados ao clorofórmio. O efeito solvente foi avaliado através da mensuração da profundidade de penetração de um pequeno marcador, de peso e formato fixo, dentro do disco de guta-percha coberta com solução teste. O efeito dos solventes foi analisado em períodos de 1, 2, 5, 10, 15 e 30 minutos e o resultado mostrou que o clorofórmio teve efeito marcadamente superior aos outros. 
Oyama et al. (2003) verificaram a eficácia dos solventes xilol, eucaliptol, óleo da casca de laranja e halotano em dissolver os cones de guta percha através de perda de peso. O efeito solvente foi analisado para os tempos de 1, 5, 10 e 15 minutos. Os resultados mostraram que o xilol foi o mais eficaz para o tempo de 5 minutos, porém ao final dos tempos estudados o óleo da casca de laranja mostrou ser mais eficaz seguido por xilol, eucaliptol e halotano.

Como pudemos observar os solventes têm como objetivo facilitar a remoção do material obturador, através de solubilização deste, com o destaque especial para clorofórmio e xilol. No entanto, existe uma grande preocupação em relação aos efeitos deletérios relatados particularmente a estes dois solventes. Assim, no início da década de 90 ocorreu uma intensa busca a um solvente alternativo.

Verificando a necessidade de identificar um outro solvente de gutapercha que não estivesse listado como possível carcinogênico e que pudesse ser mais eficaz que o eucaliptol, Wourms et al. (1990) propuseram a avaliação de um solvente eficaz em dissolver a guta-percha. Para tanto, a solubilidade de guta percha com peso padronizado foi testado em $5 \mathrm{~mL}$ de cada solvente. Dos 32 tipos de solventes analisados os autores relataram que o halotano demonstrou qualidade de trabalho favorável, em relação aos demais utilizados até aquele momento.

Kaplowitz, em 1990, mencionou que a utilização do clorofómio em seres humanos foi proibida pela FDA (Foods and Drugs Administration), desde 1976. Assim, o autor estudou os solventes: turpentina, óleo de 
melaleuca, eucaliptol, óleo de pinha branca e óleo de agulha de pinha e os comparou ao clorofórmio, na tentativa de encontrar um alternativo aceitável para a solubilização da guta-percha. Concluiu que todos os solventes estudados dissolveram os corpos de prova em no mínimo 50\% em 15 minutos a $37^{\circ} \mathrm{C}$, enquanto que o clorofórmio e a turpentina os haviam dissolvido completamente.

Ladley et al. (1991), preocupados com o potencial carcinogênico do clorofórmio, direcionaram a pesquisa em encontrar um solvente alternativo. Para tanto, avaliaram o halotano, um anestésico comumente utilizado por inalação. Observaram que possui ação em dissolver a guta-percha e acrescentaram ser um produto não irritante, não inflamável e nem explosivo.

Hunter et al. (1991) procuraram produto alternativo ao clorofórmio e investigaram o halotano e o eucaliptol e concluíram que foram alternativos aceitáveis para a prática clínica.

Pécora et al. (1992), preocupados com os canais radiculares obturados com diferentes tipos de cimentos e na eventual necessidade de um retratamento de um canal que estivesse obturado somente com cimento de óxido de zinco e eugenol, propuseram um óleo essencial vegetal eficaz na desintegração desse cimento no interior do canal radicular. Sabe-se que, esse tipo de cimento não é solúvel em solventes químicos apropriados para a guta-percha, além de não apresentar colofônia, uma resina vegetal para proporcionar adesividade, plasticidade e resistência à solubilidade, na sua composição. O óleo, extraído do epicárpio do fruto da "laranjeira doce"-Citrus aurantium é de fácil obtenção, propiciaria uma rápida desobturação do canal 
obturado somente com cimento de óxido de zinco. Os experimentos in vitro demonstraram que a desobturação de um canal radicular obturado com cimento de óxido de zinco e eugenol, com auxílio de alargador e clorofórmio, gastou em média 25 minutos e que a desobturação com o auxílio de um alargador e óleo de laranja gastou em média, 6 minutos. Já os experimentos in vivo mostraram que quando não foi possível realizar desobturação de um canal radicular tratado com cimento de óxido de zinco e eugenol com auxílio dos solventes comumente utilizados (éter, clorofórmio, xilol e eucaliptol), já o óleo de laranja promoveu a desobturação de maneira bastante aceitável.

Pécora et al. (1993) estudaram in vitro o tempo de amolecimento de cones de guta-percha através da ação de cinco solventes químicos: xilol, clorofórmio, turpentina, eucaliptol e óleo de laranja. Para isso utilizaram um aparelho que reproduziria a força de penetração de uma lima endodôntica. As raízes de dentes previamente obturadas e seccionadas constituíam o corpo de prova. Os autores observaram que o clorofórmio proporcionou maior rapidez de amolecimento sobre a guta-percha e o mais lento foi o eucaliptol. O óleo de laranja apresentou ação semelhante ao xilol. Relataram ainda que seu uso não apresenta efeitos deletérios à saúde, possui característica química de pouca solubilidade em água, porém solúvel em álcool, usado em farmacologia para aromatizar e dar sabor, tendo ainda ação expectorante.

Diante da controvérsia existente sobre a toxicidade de clorofórmio, os cirurgiões dentistas deveriam desejar uma técnica de retratamento 
endodôntico que pudesse eliminar a utilização do clorofórmio e que ainda alcançasse um resultado eficaz e eficiente.

Spanó et al. (1995) estudaram a capacidade solvente dos óleos essenciais: eucaliptol, turpentina, óleo de laranja e suas respectivas associações sobre a guta percha, utilizando o clorofórmio como controle. Os autores tinham como objetivo encontrar um alternativo para esse solvente tóxico. Para tanto utilizaram um aparelho denominado Penetrômetro PVS, os dados obtidos foram anotados e os resultados mostraram que clorofórmio foi o melhor, seguido por óleo de laranja e associação óleo de laranja+turpentina.

Wilcox (1995) comparou a capacidade de halotano e clorofórmio em remover a guta-percha e o tempo necessário para retratar o canal radicular. Para esse experimento foram utilizados trinta dentes pré-molares inferiores, preparados, obturados e armazenados em umidade por catorze meses. Posteriormente foram retratados, utilizando-se em um grupo o solvente clorofórmio e no outro o halotano. Os resultados mostraram que não houve diferença significante entre os solventes testados. Quanto à decisão sobre qual solvente utilizar para o retratamento a autora sugeriu um balanço entre uso prático eficiente de tempo e a necessidade de segurança.

Görduysus et al. (1997) avaliaram comparativamente a eficiência de solubilização de clorofórmio, xilol, eucaliptol, halotano, turpentina, acetona, álcool e óleo de melaleuca em um corpo de prova de guta-percha. A análise foi realizada através da perda de peso do corpo de prova nos períodos de 2 , 24 e 48 horas. Os resultados revelaram que o halotano, clorofórmio e xilol 
apresentaram efetividade maior e concluíram que o halotano pode ser um alternativo ao clorofórmio e xilol.

Uemura et al., em 1997, avaliaram eucaliptol e d-limonene na capacidade de dissolver guta-percha, no intuito de investigar substitutos não carcinogênicos. Os autores relataram que ao realizar o estudo observaram a necessidade de reposição constante do clorofórmio, reforçando a necessidade de escolha para outros solventes analisados neste estudo.

Durante o levantamento dos solventes alternativos observamos também que houve a preocupação quanto ao efeito destes æ̀s estruturas do órgão dental.

Kaufman et al., em 1997, estudaram o efeito de solventes de guta percha sobre os níveis de cálcio e fosfato em cortes de dentina humano. Para este estudo utilizaram dentes humanos intactos e frescos onde foram cortados e tratados com clorofórmio, xilol e endosolv E. O tratamento consistiu em embeber os espécimes de cada grupo durante 15 e 30 minutos em solução teste. Após esses intervalos os espécimes foram enxaguados, secos e preparados para análise de espectrometria dispersiva de energia de superfície. Os níveis de cálcio e fósforo foram anotados e as diferenças entre os grupos teste foram analisadas estatisticamente. As mudanças dos níveis de cálcio e fósforo foram mínimas e estatisticamente não significantes. Os resultados mostraram que todos os solventes estudados possuíram efeito similar sobre a estrutura de dentina e concluíram que o clínico deveria selecionar o solvente apropriado para o procedimento de retratamento de acordo com o seu julgamento. 
Rotstein et al. (1999) avaliaram o efeito de solventes: clorofórmio, xilol, e halotano sobre a microdureza de esmalte e dentina e concluíram que todos causaram um efeito de amolecimento significante em ambas estruturas e este amolecimento foi aparente após 5 minutos de tratamento.

Com a necessidade de determinar guias de recomendações adequadas para a indústria de higiene, pesquisa em espécies de animais de laboratório foi realizada para averiguar a toxicidade por inalação crônica ao vapor de clorofórmio.

Torkelson et al. (1976) determinaram a toxicidade de clorofórmio em animais de laboratório em única ou repetida exposição. A absorção de clorofórmio através da pele dos coelhos foi aparente, mas não excedeu ao dano agudo causado em prática. O clorofórmio líquido produziu injúria leve aos olhos de coelhos em uma semana. Exposição repetida de 1 hora ao longo de 5 dias da semana, durante 6 meses, com exposição ao vapor de 25 ppm (partícula por milhão) de clorofórmio resultou em efeito adverso em todos espécimes estudados: ratos, coelhos, porcos e cães. O efeito de 25 ppm foi leve e reversível. Com base nos dados experimentais e em relatos publicados com carbono tetracloro, os autores sugeriram que profissionais com exposição repetida ou prolongada devem manter a concentração de exposição ao clorofórmio abaixo de 25 ppm.

Após a proibição do uso de clorofórmio em medicamentos e produtos cosméticos houve confusão com relação ao emprego desta substância na odontologia, por ser considerado não seguro. Assim, McDonald \& Vire (1992) realizaram uma revisão sobre o papel do clorofórmio na odontologia e 
descreveram uma investigação clínico-ocupacional com os possíveis efeitos deletérios do uso do clorofórmio no consultório. Os autores realizaram tratamento endodôntico utilizando clorofórmio e verificaram que não houve efeito lesivo àsaúde tanto para o profissional quanto para o assistente. Além disso, os níveis de vapor no ar ficaram bem abaixo dos níveis recomendados pela Saúde Ocupacional e Administração de Segurança. Os autores concluiram que com uso cuidadoso e controlado, o clorofórmio pode ser adjunto útil na prática odontológica e que a Food and Drug Administration (FDA) não tinha jurisdição sobre o uso de clorofórmio na prática clínica e não provaram que o clorofórmio fosse realmente carcinogênico para humanos.

O método de avaliação biológica in vitro foi descrito inicialmente no século XIX, principalmente no campo de embriologia. Foi Harrison (1907) apud Freshney (2000) quem demonstrou a manutenção da função normal através de cultura de tubo medular do embrião do sapo. A partir daí, as técnicas de cultura celular se desenvolveram rapidamente.

Kawahara et al., em 1968, conduziram trabalho de teste biológico de materiais odontológicos através de cultura de tecidos e relataram que os métodos in vitro permitiram um controle mais fácil e com maior precisão estatística. Relatou a impossibilidade de investigar continuamente a reação tecidual e celular dos materiais, utilizando técnica in vivo, além de mostrarem resultados com grandes desvios devido à existência de fatores desconhecidos. Advertiram que os resultados de pesquisas poderiam variar de acordo com o método utilizado, principalmente com relação ao preparo, estado físico, área e contato do material a ser testado. Mencionaram que a 
citotoxicidade de alguns cimentos odontológicos estudados estavam relacionados à mudança de $\mathrm{pH}$ do meio de cultura para ácido. $\mathrm{O}$ principal fator causador de dano celular era a alta acidez por longo período. Ressaltaram ainda que o método in vitro tornou-se um método importante para padronização biológica de materiais odontológicos.

Browne \& Tyas (1979) realizaram uma revisão sobre os tipos celulares, o estado físico dos materiais, o método para estabelecer o contato célula e material-teste e o critério de avaliação da citotoxicidade dos materiais restauradores. Os autores alertaram que não existe uma correlação adequada entre os resultados obtidos in vivo e in vitro e por isso os resultados deveriam ser interpretados com precaução. Ainda, os autores sugeriram o desenvolvimento de um sistema teste que permitisse a simulação clínica real e o estabelecimento da patogenia do dano celular após exposição aos materiais teste.

Existem três técnicas básicas in vitro: cultura de órgão, cultura tecidual e cultura celular. Neste momento enfocaremos a técnica de cultura celular.

A cultura in vitro foi introduzida como um método de estudar o comportamento de células animais sem a interferência de variações sistêmicas, como homeostase normal e estresse experimental, que poderia surgir no animal. Pode ser adaptado para determinar efeitos de curto e longo prazo além de propiciar condições laboratoriais estritas e ainda é reproduzível, rápido, barato e sem limitação ética (Spangberg \& Conn, 1978; Browne, 1988; Freshney, 2000). 
Testes de viabilidade são utilizados para medir a proporção de células viáveis seguido a um procedimento traumático potencial, tais como a desagregação primária, separação celular ou durante a fase de congelamento e descongelamento.

Pela literatura citada até o momento sobre os solventes alternativos, e das mais novas tendências conferimos, portanto, a necessidade de substâncias biocompatíveis. Diante disto, deve-se conseqüentemente realizar testes apropriados de citotoxicidade e adicionalmente interpretar corretamente estes testes e transportá-los às condições clínicas.

Grande gama de modelos experimentais foi utilizada, o que tornou pesquisa comparativa da literatura muito difícil. Diante desse fato, Spangberg \& Pascon (1988) verificaram a importância do preparo dos materiais para expressar a citotoxicidade, durante uma avaliação in vitro de biomateriais, sob condições de cultura idênticas. $O$ resultado mostrou que 0 preparo do material pode alterar significativamente o efeito citotóxico aparente de um material. Os autores concluíram que a comparação de resultados de experimentos in vivo e in vitro pode ser realizada somente quando as condições de cultura e materiais forem similares. A utilização de materiais teste através de preparo artificial não forneceu resposta apropriada; com relação a citotoxicidade geral, tais ajustes auxiliaram no estudo dos componentes dos materiais e do mecanismo de toxicidade.

A guta-percha tem sido o material mais amplamente utilizado como material obturador, por possuir baixa toxicidade e ser inerte. Porém, recentemente, as suas características têm sido alteradas com o propósito de 
ativar as propriedades complementares, o que poderia potencializar outras reações teciduais ao novo material. Diante disso, Pascon \& Spangberg (1990) propuseram um trabalho in vitro sobre a toxicidade de algumas marcas comerciais de guta-percha, através do teste de liberação de radiocrômio. A guta-percha, após ser dissolvida por clorofórmio ou aquecida, foi espalhada até cobrir o fundo do recipiente-teste e a seguir uma suspensão de células L929 foi adicionada ao recipiente. Após a incubação a $37^{\circ}$, por 4 e 24 horas, o radiocrômio extra celular no meio de cultura foi mensurado e calculado, em termos percentuais. A liberação espontânea de radiocrômio foi utilizada como controle e o resultado foi considerado dentro dos limites de normalidade em 4 ou 24 horas. Todas as guta-perchas dissolvidas em clorofórmio mostraram baixa toxicidade em 4 horas, porém, quando esta foi aquecida, houve diferença significante em 4 horas; ambas foram tóxicas quando deixadas por 24 horas. Os materiais crus não foram tóxicos, mas o óxido de zinco e os íons de zinco mostraram marcada toxicidade. Todos os cones de guta-percha testados foram tóxicos ao longo período de observação e a toxicidade foi atribuída àinfiltração de íons zinco dentro dos fluidos.

Barbosa et al. (1994) avaliaram o efeito citotóxico in vitro de solventes como o halotano e turpentina e os compararam com o do clorofórmio. Os autores utilizaram o método de liberação de radiocrômio em cultura de células, de fibroblastos de ratos, L929. Observaram que todos os solventes testados foram citotóxicos e causaram o mesmo nível de dano celular. Após 24 horas de evaporação no ar, o halotano e o clorofórmio não demonstraram 
efeito citotóxico, porém o clorofórmio residual permaneceu por um certo período de tempo e a toxicidade da mistura foi real e o halotano não pareceu ser um solvente alternativo ideal.

Chang \& Chou em 2001 avaliaram a citotoxicidade do halotano, em cultura de células fibroblásticas de gengiva humana, relacionando a dose de exposição, freqüência e duração. Os materiais foram preparados pela dissolução de $1.0 \mathrm{~g}$ de guta-percha em $5 \mathrm{~mL}$ de halotano e conservados em frasco de vidro com tampa. O halotano foi diretamente diluído em meio de cultura, sendo a concentração final de 1:5, 1:10, 1:20, 1:40 e 1:80. Os autores concluíram que a baixa concentração e quantidade pequena de solvente podem minimizar o efeito citotóxico do tecido do hospedeiro. Ainda, os autores comentaram que o uso de halotano poderia impedir a cicatrização do tecido periapical e por isso, não deveria ser um solvente de escolha para amolecimento de guta-percha.

A forma de avaliação do ensaio, após o tratamento das células com os materiais testes, pode ser verificada através de: viabilidade, sobrevivência, metabolismo, transformação ou irritação celular. A maioria dos testes de viabilidade celular depende da ruptura da integridade de membrana, que é determinada pela pigmentação de células que são normalmente impermeáveis ao corante. Portanto, o seu efeito é direto, apesar de não ditar a sobrevivência final (Freshney, 2000).

Scelza et al. (2001) avaliaram efeito citotóxico de ácido cítrico a 10\% e EDTA-T, substâncias químicas utilizadas em canal radicular. Foram analisadas em cultura de fibroblastos usando método de células coradas 
com o azul Trypan. As soluções foram diluídas para 1, 0.1 e $0.01 \%$ em meio de cultura e aplicadas em cultura de células NIH 3T3. O crescimento celular em meio de cultura DMEM serviu como controle. Após 0, 6, 12 e 24 horas (viabilidade a curto prazo) e 1, 3, 5 e 7 dias (sobrevivência a longo prazo) as células foram contadas, usando hemocitômetro, sob auxílio de microscópio óptico de fase invertida. Nos testes de curto prazo, a viabilidade celular alcançou de 85 a 99\% para todos os grupos experimentais, sem diferença estatística quando comparado ao grupo controle, exceto para o grupo tratado com EDTA-T 1\%, que causou uma diminuição progressiva na viabilidade celular. Em testes de longo prazo, todas as culturas aumentaram do primeiro ao último período do experimento, não mostrando inibição de proliferação celular, exceto o grupo tratado com EDTA-T 1\%, que preveniu totalmente o crescimento celular. Todas as diluições de ácido cítrico $10 \%$ foram mais biocompatíveis que EDTA-T. Culturas tratadas com ácido cítrico tiveram uma porcentagem maior de viabilidade em teste de curto prazo, e as células mantiveram sua capacidade de renovação própria.

No retratamento endodôntico, cujo procedimento recomendado é a remoção do material obturador presente dentro do canal radicular, o solvente é a substância mais amplamente utilizada, devido a seu fácil uso e sua média de sucesso clínico ser alta. No entanto, os efeitos citotóxicos e a possível difusão para os tecidos periapicais e sistêmicos, bem como os possíveis efeitos mutagênicos e carcinogênicos são aparentes.

Portanto, com enfoque na literatura e nas mais recentes tendências, torna-se estimulante procurar substâncias com ação solvente, para uso 
durante o procedimento de retratamento endodôntico, e ao mesmo tempo observamos a necessidade de materiais biocompatíveis, que impõem a utilização de testes adequados, interpretação dos dados obtidos pelo teste e aplicação desses resultados às condições de uso clínico. 


\section{PROPOSIÇÃO}

Este estudo propõe-se a comparar a ação citotóxica in vitro de alguns solventes utilizados em terapia de retratamento endodôntico: óleo da casca de laranja, eucaliptol, xilol, clorofórmio e halotano em diferentes situações de preparo (concentrações finais e tempo de contato) e diversas condições de contato sobre as células (direto ou indireto). 


\section{MATERIAL E MÉTODOS}

\subsection{Material}

Álcool absoluto - Fórmula \& Ação Farmácia de Manipulação- São Paulo, SP Banho Maria - Plyscience, Illinois, EUA

Câmara de Neubauer

Capela de Fluxo laminar

Centrífuga - Forma Scientific Division, Ohio, EUA

Cronômetro

DMEM-Dulbelcco's modified Eagle Médium - Gibco, EUA

DMSO-di-metil sulfóxido - Gibco, EUA

FBS - soro fetal bovino - Gibco, EUA

Frascos plásticos para cultivo celular com 25 e $75 \mathrm{~cm}^{2}$ de área cultivável

Frasco de plásticos vials para contagem de viabilidade celular - Eppendorf

Frasco de vidro âmbar para armazenar material teste

Incubadora com controle de temperatura e pressão - Forma Scientific, Ohio, EUA

Lamínula de vidro com $5 \mathrm{~mm}$ de diâmetro

Linhagem de fibroblastos de embriões de camundongos NIH-3T3 - cedida pelo Laboratório de Anatomia e Biologia Celular do ICB-USP 
Microscópio invertido de fase - Nikon, Japão

Pipetador automático

Pipetas descartáveis de $2 \mathrm{~mL}, 5 \mathrm{~mL}, 10 \mathrm{~mL}$ e $20 \mathrm{~mL}$

Placa de 24 poços de cultivo celular - Corning Incorporated, New York, EUA Pontas para pipetas

Solução antibiótica P/S (penicilina/estreptomicina) - Gibco, EUA

Solução tampão de fosfato -PBS- Gibco, EUA

Solução de tripsina - Gibco, EUA

Tubos para congelamento de células

Solução de azul de Trypan a 0.4\% - Gibco, EUA

Solventes - Óleo da casca de laranja, eucaliptol, xilol, clorofórmio - Fórmula \& Ação Farmácia de Manipulação, São Paulo, SP

Solvente halotano - Cristália - Produtos Químicos Farmacêuticos Ltda, SP, Brasil

\subsubsection{Linhagem celular}

Para este estudo foram utilizadas células NIH 3T3, fibroblastos originados de embriões de camundongos Swiss, linhagem celular contínua (Figuras 4.1 e 4.2), cedida pelo Laboratório de Biologia Celular e Anatomia Funcional do Departamento de Anatomia, ICB-USP. 


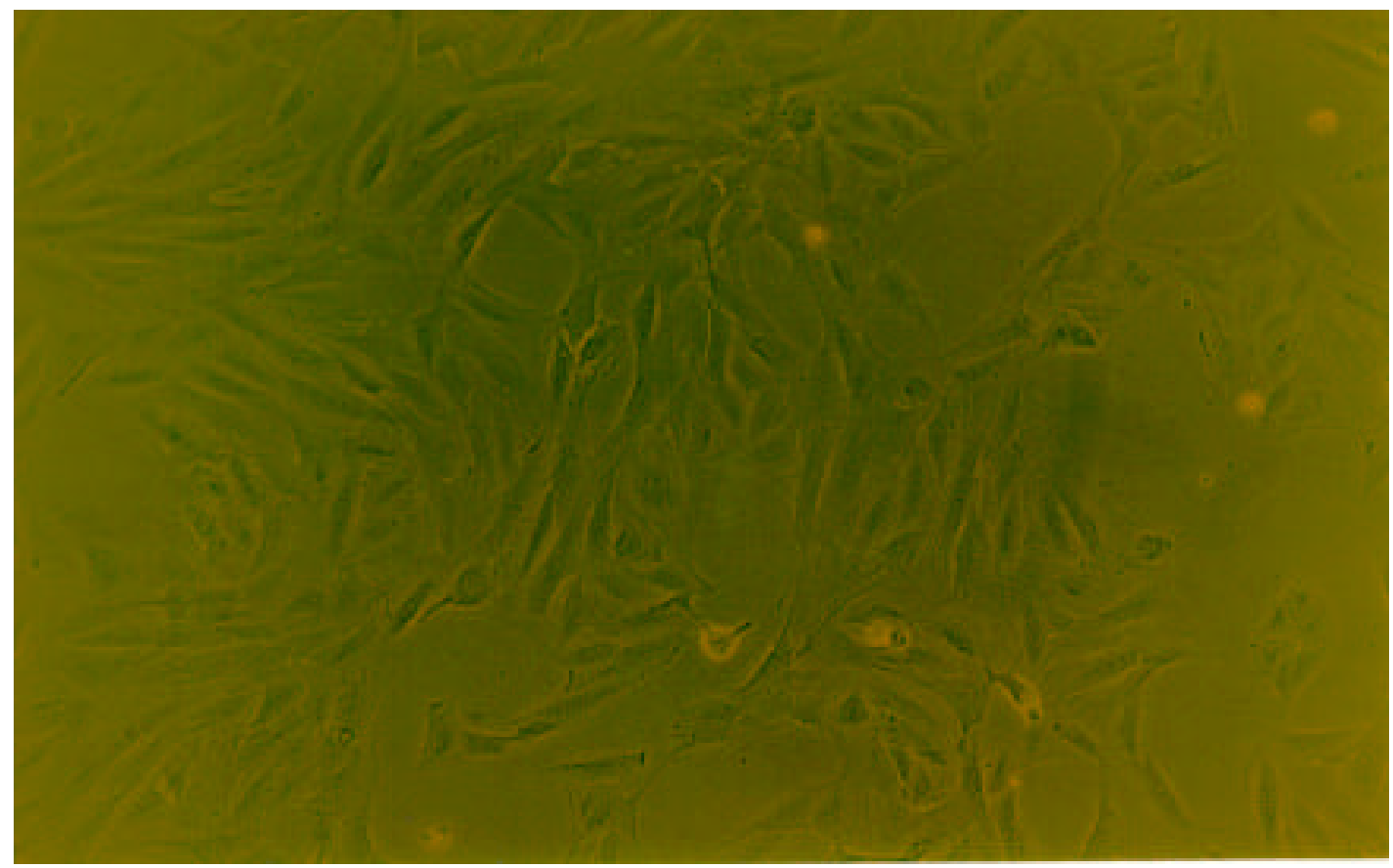

Figura 4.1 - Fotomicrografia de cultura de células de fibroblastos NIH 3T3, com filtro verde (aumento de 100X)

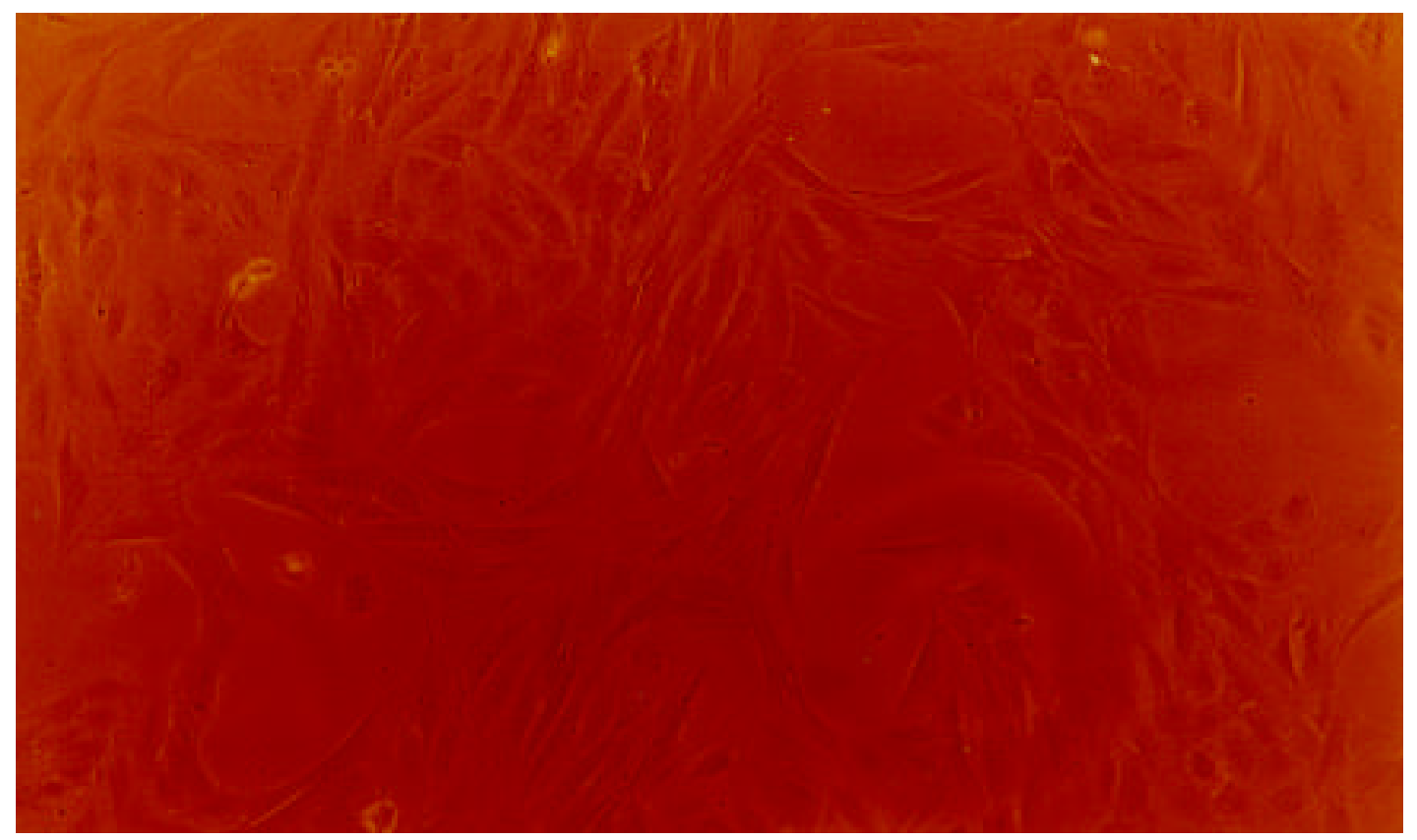

Figura 4.2 - Fotomicrografia de células de fibroblastos NIH 3T3 em cultura, sem filtro (aumento de 100X) 


\subsubsection{Grupos experimentais}

Como já citado anteriormente, foram testados alguns dos solventes utilizados durante o processo de retratamento endodôntico na desobturação do canal radicular. A ação destes solventes nas culturas celulares foi analisada quanto à viabilidade ou não das mesmas e para isto foram determinados os seguintes grupos experimentais:

Grupo 1 - Controle - células mantidas em meio de cultura, na ausência de qualquer tratamento;

Grupo 2 - Tratamento com Óleo da casca de laranja;

Grupo 3 - Tratamento com Eucaliptol;

Grupo 4 - Tratamento com Xilol;

Grupo 5 - Tratamento com Clorofórmio;

Grupo 6 - Tratamento com Halotano.

\subsubsection{Etapas experimentais}

Os solventes foram estudados em diferentes situações de preparo e contato com as células de fibroblastos e as etapas experimentais foram:

1. solvente com diluição final no meio de cultura de $0,5,15,25,50$ e $100 \%$ para o tempo de 5 minutos.

2. solvente com diluição final no meio de cultura de 15 e $25 \%$ para o tempo de 10 e 15 minutos.

3. Solvente em contato direto com as células por meio de lamínula de vidro acrescido de DMEM e em contato indireto onde o DMEM foi 
depositado sobre as células de fibroblastos e o solvente depositado sobre este meio na concentração final de $5 \%$ para o tempo de 5 minutos.

4. solvente solubilizado em álcool absoluto na proporção de 1:1 e diluído em DMEM com concentração final de $5 \%$ para o período de 5 minutos.

\subsection{Métodos}

\section{2.1 Cultivo celular}

As células foram descongeladas, em banho-maria, transferidas para placas de cultura apropriadas e mantidas em estufa de $\mathrm{Co}_{2}(5 \%)$ a $37^{\circ} \mathrm{C}$. As células foram cultivadas em meio de cultura DMEM (Gibco, USA) suplementado com P/S (Gibco, USA), contendo 10\% de FBS (Gibco, USA). O crescimento celular foi acompanhado a cada 24 horas, com auxilio de microscópio de fase invertido e o meio de cultura trocado a cada dois dias. $\mathrm{O}$ subcultivo foi realizado ao se observar formação de uma monocamada celular com mais de $80 \%$ de confluência. Para a observação da viabilidade celular frente ao tratamento com os diferentes solventes, as células foram plaqueadas em número aproximado de $12 \times 10^{4}$ células/poço, em placas de cultivo contendo 24 poços, com uma área aproximada de $1,5 \mathrm{~cm}^{2}$ cada. Todos os experimentos foram realizados em quadruplicata sob ambiente de fluxo laminar (Figura 4.3). 


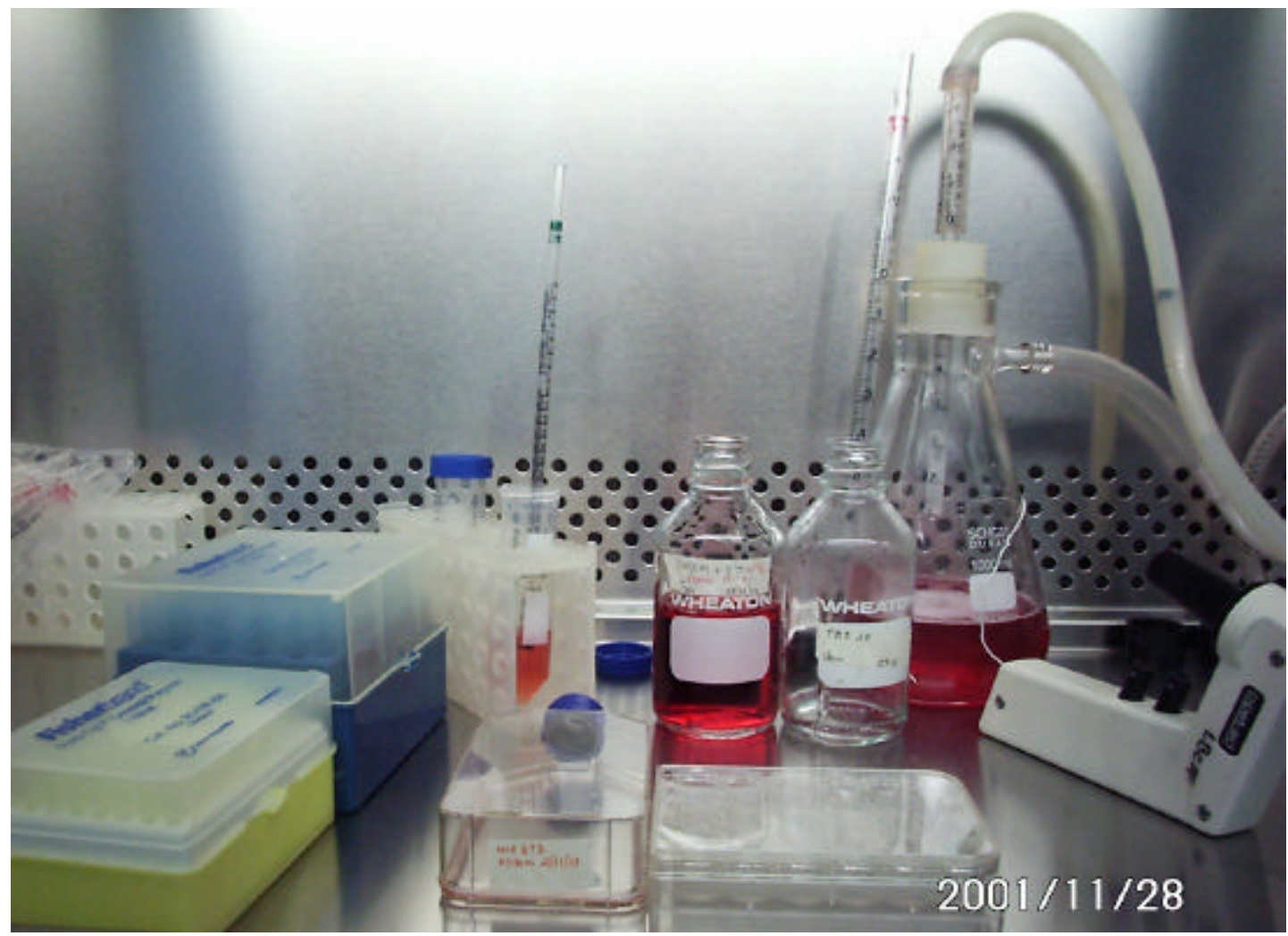

Figura 4.3 - Área interna do Fluxo laminar para cultivo celular

\subsubsection{Tratamentos}

Vinte e quatro horas antes do início dos tratamentos com os diferentes solventes, as células foram carenciadas de soro, sendo o meio de cultura substituído para DMEM contendo $0,5 \%$ de FBS. Os tratamentos foram realizados inicialmente avaliando o efeito de diferentes concentrações dos solventes no meio cultura, ou seja, realizando uma curva dose-resposta para cada um dos solventes. Posteriormente, avaliou-se o efeito de diferentes tempos de tratamento com os solventes sobre a viabilidade celular, curva tempo-resposta. Cada experimento foi repetido três vezes. 
Considerando que os solventes a serem testados não apresentaram grande solubilidade aquosa, alguns experimentos foram realizados solubilizando os solventes previamente em álcool absoluto, apesar de na prática clínica não ser esta a conduta utilizada. Da mesma forma, os experimentos foram realizados em quadriplicata e um número mínimo de três experimentos realizados para cada situação em questão.

\subsubsection{Determinação da viabilidade celular}

A ação dos solventes sobre a viabilidade celular foi determinada pelo método de exclusão do Trypan Blue. Este método consiste no fato de que este corante não sendo lipofílico não consegue entrar normalmente nas células, o que passa a ocorrer caso haja a ruptura da membrana plasmática, um típico sinal que antecede a morte celular. Assim, somente as células em morte celular se apresentam coradas em azul e com limites irregulares. As demais se apresentam arredondadas, transparentes, com a membrana refringente e os com limites nítidos (Figura 4.4). A contagem de células foi determinada por amostragem, utilizando-se um hemocitrômetro ou Câmara de Neubauer e levado ao microscópio de luz.

O percentual de viabilidade celular foi calculado pela razão:

$n^{0}$ de células viáveis $X 100 / n^{0}$ total de células 


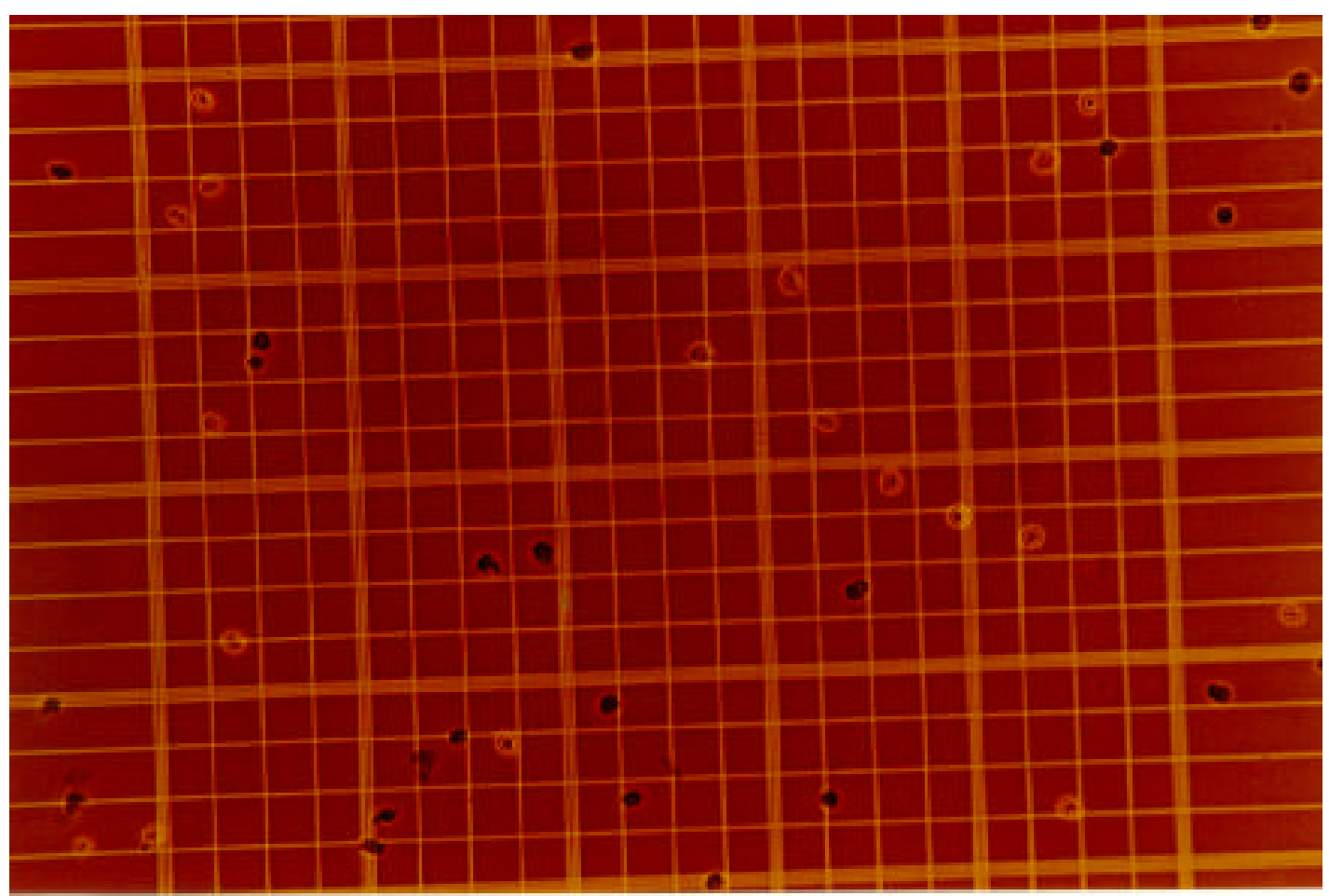

Figura 4.4 - Fotomicrografia da câmara de Neubauer, somente as células em morte celular se apresentam coradas em azul e com limites irregulares. As demais se apresentam arredondadas, transparentes, com a membrana refringente e com limites nítidos (aumento de 200x)

\subsection{Análise estatística}

Os dados obtidos foram comparados através de Análise de Variância (ANOVA), e quando foi significante foi aplicado pós-teste (Tukey-Kramer), considerando significativas as diferenças entre grupos com $\mathrm{p} \quad 0.05$. 


\section{RESULTADOS}

Comparamos a reação celular de fibroblastos ao contato com os solventes de guta-percha, utilizados durante o retratamento endodôntico. Esta reação foi avaliada pela mensuração do número de células viáveis nas diferentes etapas experimentais e nos tempos estudados.

\section{Etapa 1 - Solvente com diluição final no meio de cultura de $0,5,10,25$, 50 e $100 \%$ para o tempo de 5 minutos}

Os valores da média \pm desvio padrão estão descritos na Tabela 5.1 e no gráfico da Figura 5.1. As Tabelas de An.A1 à An.A5 mostram os valores originais correspondentes ao número de células viáveis $\left(\mathrm{X} 10^{4}\right)$ nos diferentes grupos experimentais.

Antes da análise dos resultados, é importante ressaltar que no início do experimento, todos os poços apresentavam aproximadamente o mesmo número de células, sem diferenças significativas entre os grupos.

A análise de variância ANOVA mostrou que todos os solventes nas concentrações 0, 50 e 100\% foi considerado não significante. 
Tabela 5.1 - Valores da média \pm desvio padrão correspondentes ao número de células viáveis $\left(\times 10^{4}\right)$ quando da exposição aos solventes testados em diferentes concentrações para o período de 5 minutos. $\mathrm{n}=$ número de poços com células, utilizados para 0 tratamento

\begin{tabular}{|c|c|c|c|c|c|c|}
\hline $\begin{array}{l}\text { Concentração } \\
\text { Grupo }\end{array}$ & 0 & 5 & 10 & 25 & 50 & 100 \\
\hline $\begin{array}{c}\text { Óleo de laranja } \\
(n=12)\end{array}$ & $\begin{array}{c}9.93 \\
( \pm 1.85)\end{array}$ & $\begin{array}{c}2.68 \\
( \pm 0.88)\end{array}$ & $\begin{array}{c}0.89 \\
( \pm 0.63)\end{array}$ & $\begin{array}{c}0.083 \\
( \pm 0.16)\end{array}$ & 0 & 0 \\
\hline $\begin{array}{l}\text { Eucaliptol } \\
\qquad(n=12)\end{array}$ & $\begin{array}{r}10.46 \\
( \pm 1.26)\end{array}$ & $\begin{array}{c}0.14 \\
( \pm 0.24)\end{array}$ & 0 & 0 & 0 & 0 \\
\hline $\begin{array}{l}\text { Xilol } \\
(n=12)\end{array}$ & $\begin{array}{c}9.58 \\
( \pm 1.40)\end{array}$ & $\begin{array}{c}2.79 \\
( \pm 0.89)\end{array}$ & $\begin{array}{c}1.5 \\
( \pm 0.35)\end{array}$ & $\begin{array}{c}0.91 \\
( \pm 0.30)\end{array}$ & 0 & 0 \\
\hline $\begin{array}{l}\text { Clorofórmio } \\
\qquad(\mathrm{n}=12)\end{array}$ & $\begin{array}{r}10.14 \\
( \pm 0.93)\end{array}$ & $\begin{array}{c}0.10 \\
( \pm 0.16)\end{array}$ & 0 & 0 & 0 & 0 \\
\hline $\begin{array}{l}\text { Halotano } \\
\qquad(\mathrm{n}=12)\end{array}$ & $\begin{array}{c}9.56 \\
( \pm 0.90)\end{array}$ & 0 & 0 & 0 & 0 & 0 \\
\hline
\end{tabular}

A Tabela 5.1 nos mostra que independente do tratamento usado a viabilidade celular foi menor, quanto maior a concentração do solvente, resultando em citotoxicidade marcante. Ao analisarmos os dados dos grupos eucaliptol, clorofórmio e halotano pode-se observar que mesmo em pequenas concentrações ainda assim estes solventes apresentaram alto índice de morte celular (Figura 5.1).

O ponto $0 \%$ de concentração correspondeu à contagem inicial das células viáveis no momento da aplicação do solvente. Como podemos 
observar na Figura 5.1, os fibroblastos tratados com os solventes: eucaliptol, clorofórmio e halotano apresentaram poucas células viáveis, mesmo na menor concentração estudada. O óleo de laranja e o xilol mostraram células viáveis até a concentração de $25 \%$. Acima desta concentração mostrou total morte celular em todos os grupos estudados. 


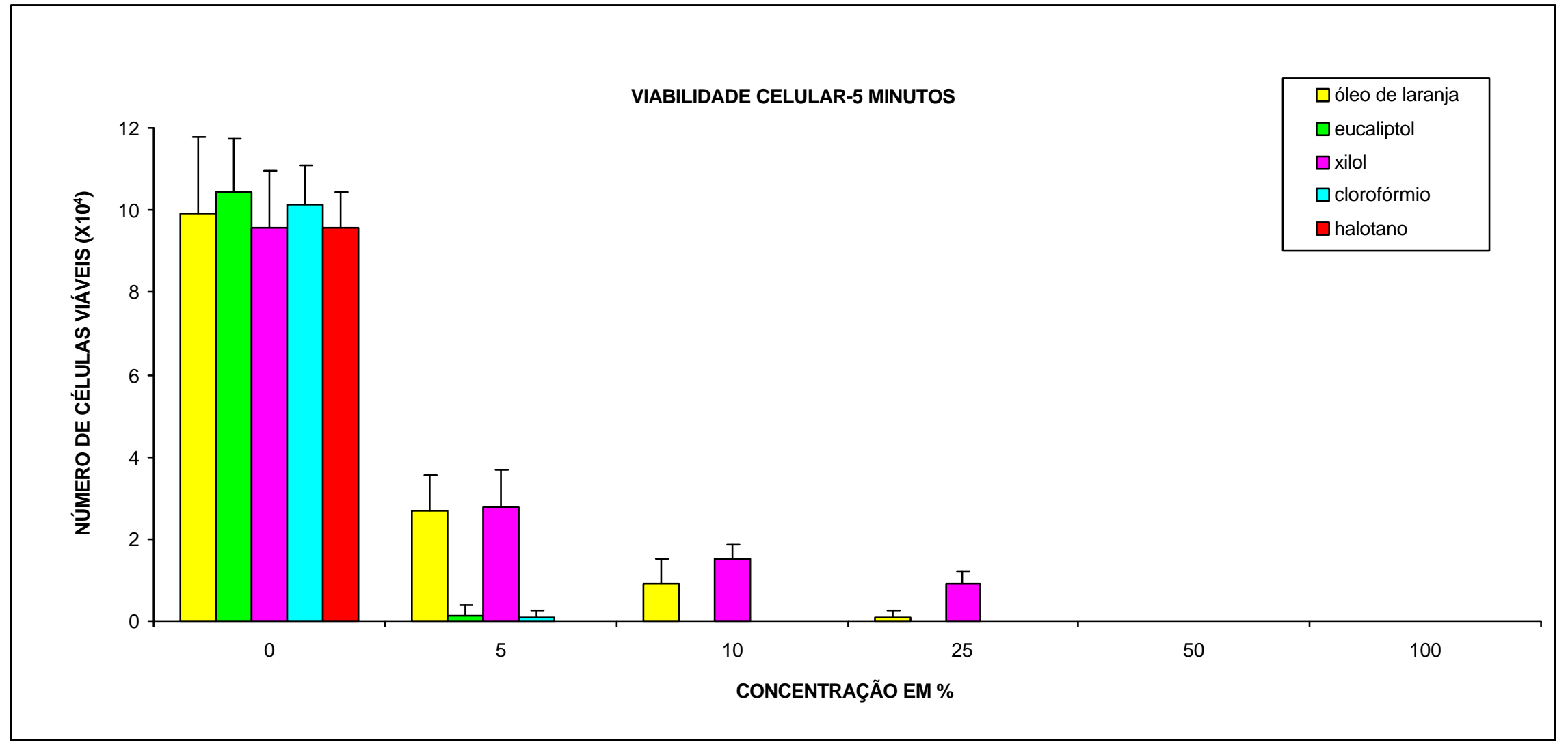

Figura 5.1 - Viabilidade celular quando da exposição aos solventes em diferentes concentrações para o período de 5 minutos. A concentração $0 \%$ corresponde ao grupo controle com número de células no momento do tratamento 


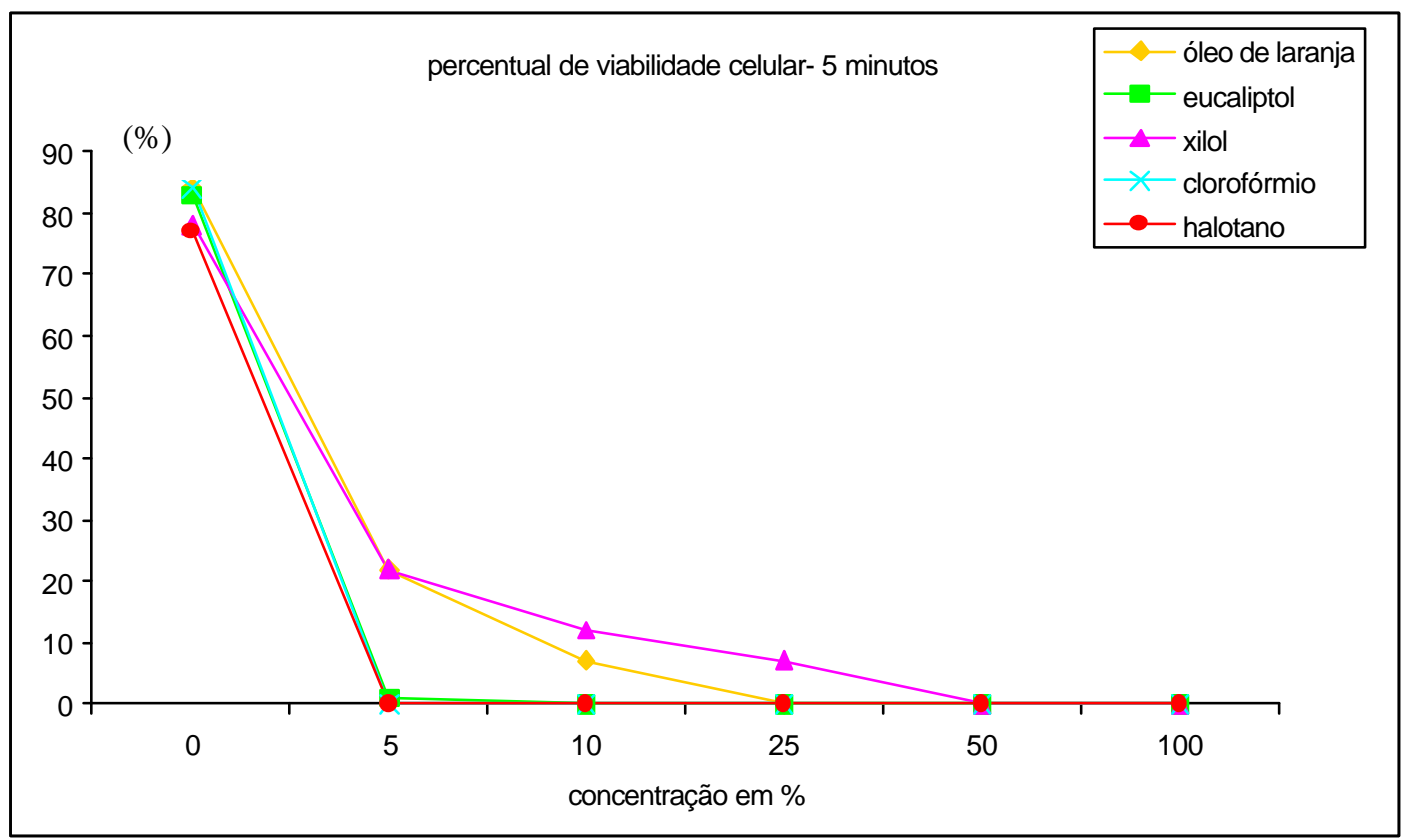

Figura 5.2-Gráfico com as curvas dos valores correspondentes a porcentagem de células viáveis após a exposição de 5 minutos nas diferentes concentrações dos solventes estudados

A Figura 5.2 nos mostra que nas concentrações de 5 e 10\% o eucaliptol, clorofórmio e halotano quando comparados ao óleo da casca de laranja e xilol apresentaram diferenças no percentual de células viáveis e estatisticamente significantes como podemos confirmar pela Tabela 5.2 e 5.3. O óleo de laranja e o xilol na concentração de $10 \%$ também apresentaram diferenças no percentual de células viáveis, porém estatisticamente não houve diferença significativa como podemos observar na Tabela 5.3.

O xilol apresentou a menor toxicidade a $25 \%$ quando comparado aos demais solventes e mostrou diferença estatisticamente significante como mostra a Tabela 5.4 . 
$\mathrm{Na}$ concentração acima de $25 \%$ todos os solventes mostraram ser citotóxicos, levando a morte de todas as células.

Tabela 5.2 - Teste de comparação múltipla Tukey-Kramer, período de 5 minutos e concentração de $5 \%$

\begin{tabular}{|c|c|c|c|}
\hline comparação & diferença da média & $q$ & Valor de p \\
\hline Laranja vs eucaliptol & 2.540 & 7.659 & s $\quad P<0.01$ \\
\hline Laranja vs xilol & -0.110 & 0.331 & ns $P>0.05$ \\
\hline Laranja vs clorofórmio & 2.580 & 7.780 & S $\quad P<0.01$ \\
\hline Laranja vs halotano & 2.680 & 8.081 & s $\quad P<0.01$ \\
\hline Eucaliptol vs xilol & -2.650 & 7.991 & $s \quad P<0.01$ \\
\hline Eucaliptol vs clorofórmio & 0.040 & 0.120 & ns $P>0.05$ \\
\hline Eucaliptol vs halotano & 0.140 & 0.422 & ns $P>0.05$ \\
\hline Xilol vs clorofórmio & 2.690 & 8.111 & s $\quad P<0.01$ \\
\hline Xilol vs halotano & 2.790 & 8.413 & s $P<0.01$ \\
\hline Clorofórmio vs halotano & 0.100 & 0.301 & ns $P>0.05$ \\
\hline
\end{tabular}

Tabela 5.3 - Teste de comparação múltipla Tukey-Kramer, período de 5 minutos e concentração de 10\%

\begin{tabular}{l|c|c|c}
\hline comparação & diferença da média & $\mathbf{q}$ & Valor de $\mathbf{p}$ \\
\hline Laranja vs eucaliptol & 0.890 & 4.783 & s $\mathrm{P}<0.05$ \\
Laranja vs xilol & -0.610 & 3.278 & ns $\mathrm{P}>0.05$ \\
Laranja vs clorofórmio & 0.890 & 4.783 & $\mathrm{~s} \quad \mathrm{P}<0.05$ \\
Laranja vs halotano & 0.890 & 4.783 & $\mathrm{~s} \quad \mathrm{P}<0.05$ \\
Eucaliptol vs xilol & -1.500 & 8.061 & $\mathrm{~s} \quad \mathrm{P}<0.01$ \\
Eucaliptol vs clorofórmio & 0.000 & 0.000 & ns $\mathrm{P}>0.05$ \\
Eucaliptol vs halotano & 0.000 & 0.000 & ns $\mathrm{P}>0.05$ \\
Xilol vs clorofórmio & 1.500 & 8.061 & $\mathrm{~s} \mathrm{P}<0.01$ \\
Xilol vs halotano & 1.500 & 8.061 & $\mathrm{~s} \mathrm{P}<0.01$ \\
Clorofórmio vs halotano & 0.000 & 0.000 & $\mathrm{~ns} \mathrm{P}>0.05$ \\
\hline
\end{tabular}

$\mathrm{s}=$ significante e $\mathrm{ns}=$ não significante (Valor de $\mathrm{q}>4.654$ significa 0 valor de $p<0.05$ ) 
Tabela 5.4 - Teste de comparação múltipla Tukey-Kramer, período de 5 minutos e concentração de $25 \%$

\begin{tabular}{l|c|c|c}
\hline comparação & diferença da média & $\mathbf{q}$ & Valor de $\mathbf{p}$ \\
\hline Laranja vs eucaliptol & 0.083 & 0.945 & ns $\quad \mathrm{P}>0.05$ \\
Laranja vs xilol & -0.827 & 9.420 & $\mathrm{~s} \quad \mathrm{P}<0.001$ \\
Laranja vs clorofórmio & 0.083 & 0.945 & ns $\mathrm{P}>0.05$ \\
Laranja vs halotano & 0.083 & 0.945 & ns $\quad \mathrm{P}>0.05$ \\
Eucaliptol vs xilol & -0.910 & 10.366 & $\mathrm{~s} \quad \mathrm{P}<0.001$ \\
Eucaliptol vs clorofórmio & 0.000 & 0.000 & $\mathrm{~ns} \mathrm{P}>0.05$ \\
Eucaliptol vs halotano & 0.000 & 0.000 & $\mathrm{~ns} \mathrm{P}>0.05$ \\
Xilol vs clorofórmio & 0.910 & 10.366 & $\mathrm{~s} \quad \mathrm{P}<0.001$ \\
Xilol vs halotano & 0.910 & 10.366 & $\mathrm{~s} \quad \mathrm{P}<0.001$ \\
Clorofórmio vs halotano & 0.000 & 0.000 & $\mathrm{~ns} \mathrm{P}>0.05$ \\
\hline S=significante e ns= não significante (Valor de q>4.654 significa o valor de $\mathrm{p}<0.05)$
\end{tabular}

Etapa 2 - Solvente com diluição final no meio de cultura de 0, 10, 25 para o tempo de 10 e 15 minutos

Etapa 2.a Tratamento no período de 10 minutos

Os valores da média \pm desvio padrão estão descritos em número de células viáveis na Tabela 5.5 e na Figura 5.3. As Tabelas de An.B1 àAn.B5 mostram os valores originais correspondentes ao número de células viáveis $\left(\mathrm{X} 10^{4}\right)$ nos diferentes grupos experimentais. 
Tabela 5.5 - Valores da média \pm desvio padrão correspondentes ao número de células viáveis $\left(\times 10^{4}\right)$ quando da exposição aos solventes testados, nas concentrações de 0, 10 e $25 \%$ para o período de 10 minutos. $n=$ número de poços com células, utilizados para 0 tratamento

\begin{tabular}{|c|c|c|c|}
\hline $\begin{array}{ll} & \text { Concentração } \\
\text { Grupos } & \end{array}$ & 0 & 10 & 25 \\
\hline $\begin{array}{l}\text { Óleo da casca de laranja } \\
\qquad(\mathrm{n}=12)\end{array}$ & $\begin{array}{l}9.83 \\
( \pm 0.19)\end{array}$ & $\begin{array}{c}0.5 \\
( \pm 0.51)\end{array}$ & $\begin{array}{l}0.06 \\
( \pm 0.06)\end{array}$ \\
\hline $\begin{array}{l}\text { Eucaliptol } \\
\qquad(\mathrm{n}=12)\end{array}$ & $\begin{array}{r}9.39 \\
( \pm 0.43)\end{array}$ & $\begin{array}{l}0.02 \\
( \pm 0.03)\end{array}$ & 0 \\
\hline $\begin{array}{l}\text { Xilol } \\
(n=12)\end{array}$ & $\begin{array}{r}10.3 \\
( \pm 0.56)\end{array}$ & $\begin{array}{c}1.3 \\
( \pm 0.95)\end{array}$ & $\begin{array}{l}0.46 \\
( \pm 0.12)\end{array}$ \\
\hline $\begin{array}{l}\text { Clorofórmio } \\
\qquad(\mathrm{n}=12)\end{array}$ & $\begin{array}{l}10.41 \\
( \pm 0.43)\end{array}$ & 0 & 0 \\
\hline $\begin{array}{l}\text { Halotano } \\
\qquad(\mathrm{n}=12)\end{array}$ & $\begin{array}{c}10 \\
( \pm 0.69)\end{array}$ & 0 & 0 \\
\hline
\end{tabular}

A Tabela 5.5 nos mostra que o tratamento das células nas concentrações de 10 e 25\%, para o tempo de 10 minutos resultou em acentuada diminuição na média do número de células viáveis. Os dados dos grupos clorofórmio e halotano revelaram que mesmo para concentração de $10 \%$ ocorreu total morte celular. 


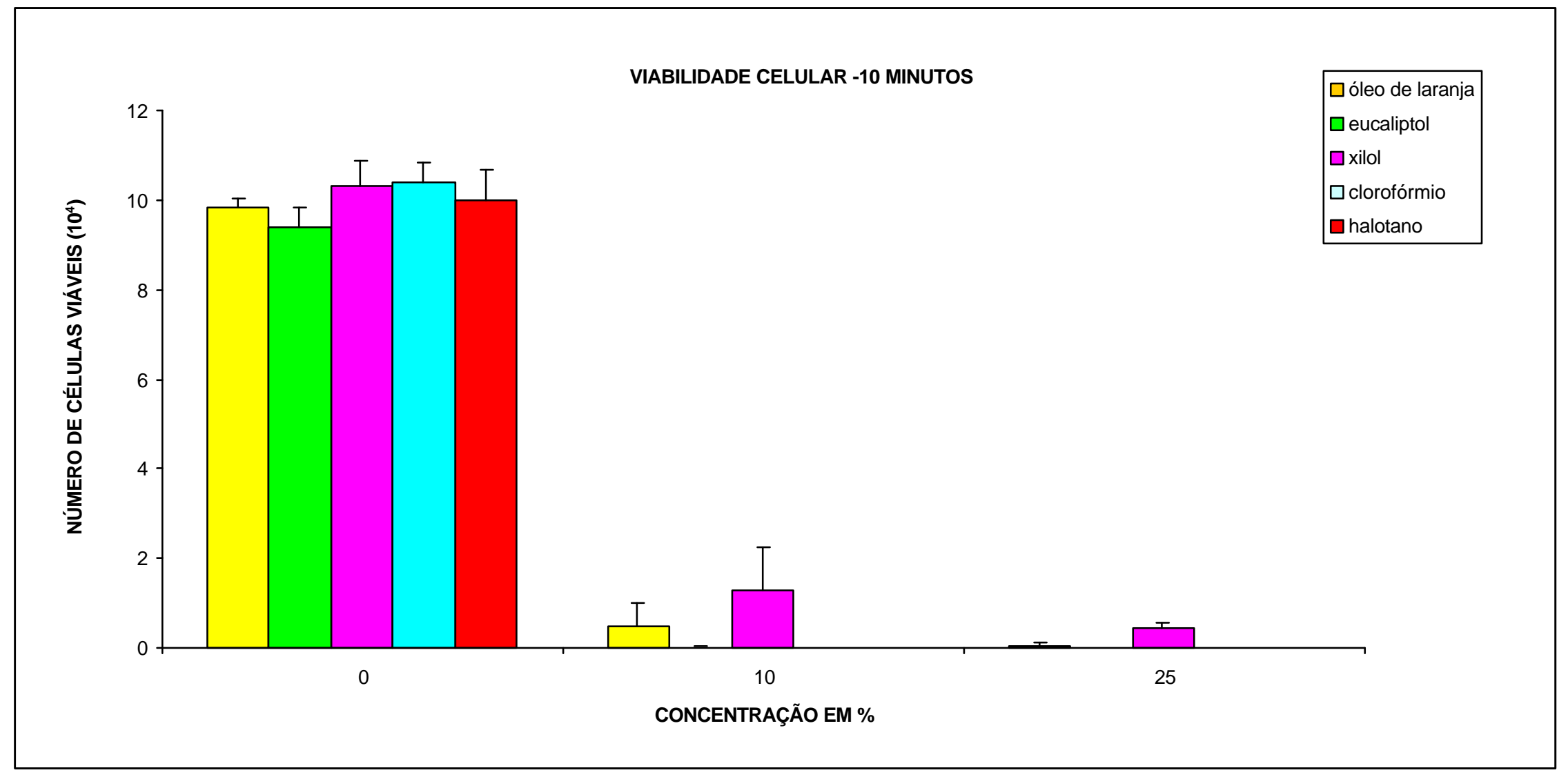

Figura 5.3 - Viabilidade celular quando da exposição aos solventes nas concentrações de 0, 10 e $25 \%$ para o período de 10 minutos. A concentração $0 \%$ corresponde ao grupo controle com número de células no momento do tratamento 


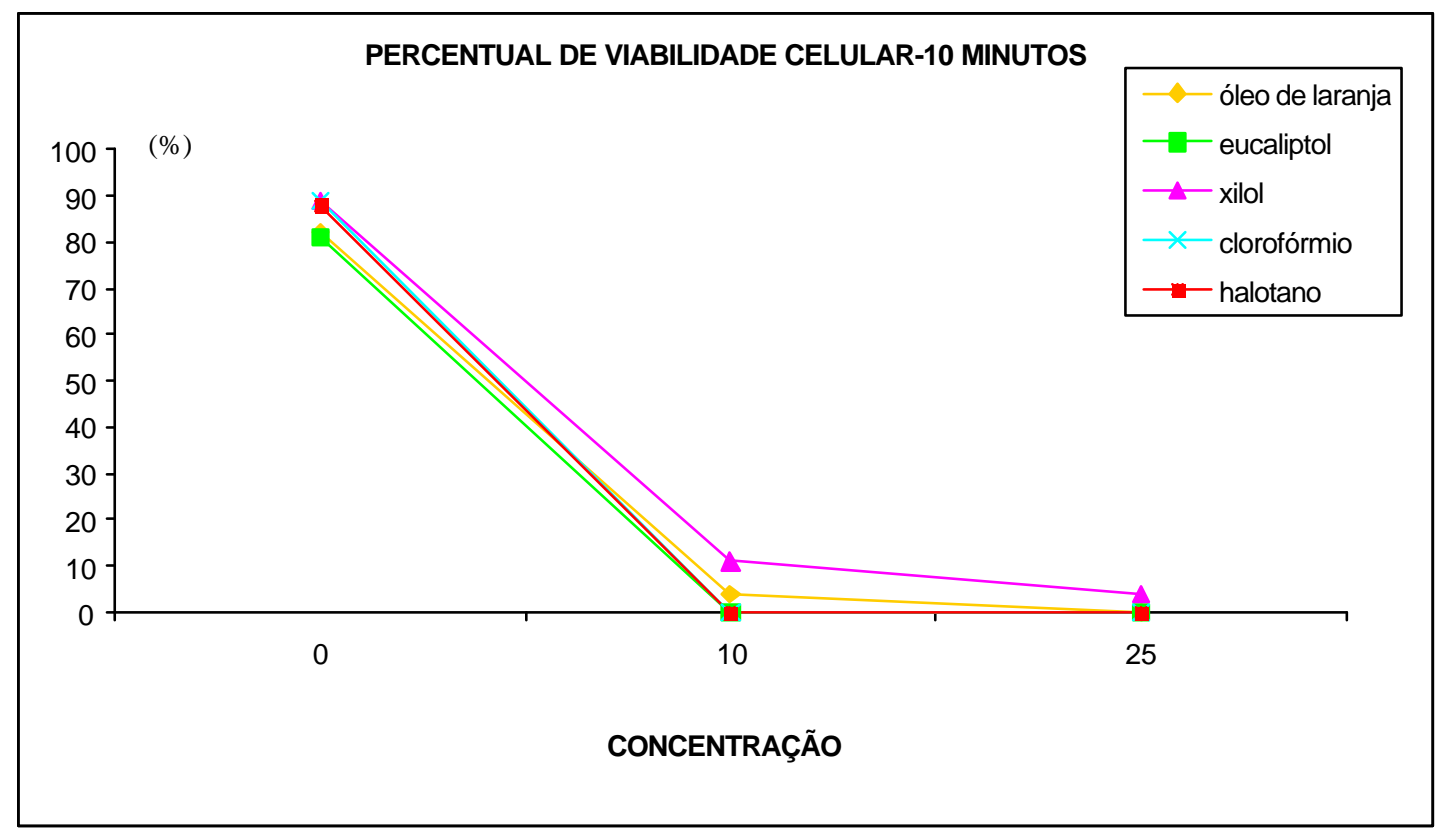

Figura 5.4- Gráfico com as curvas dos valores correspondentes a porcentagem das células viáveis após a exposição de 10 minutos nas concentrações de 0,10 e $25 \%$ dos solventes estudados

A Figura 5.4 mostra que na concentração de $10 \%$ os solventes xilol e óleo de laranja apresentaram diferenças no percentual de células em relação aos outros solventes, no entanto somente xilol mostrou diferença estatisticamente significante em relação aos demais solventes como podemos observar pela Tabela 5.6, demonstrando assim, ser o menos citotóxico neste tempo e concentrações estudados. E na concentração de 25\% o xilol mostrou diferença no percentual de células viáveis em comparação aos demais solventes e apresentou diferença estatisticamente significante como podemos ver na Tabela 5.7. 
Tabela 5.6 - Teste de comparação múltipla Tukey-Kramer, período de 10 minutos e concentração de $10 \%$

\begin{tabular}{l|c|c|c}
\hline comparação & diferença da média & $\mathbf{q}$ & Valor de $\mathbf{p}$ \\
\hline Laranja vs eucaliptol & 0.480 & 3.447 & ns $P>0.05$ \\
Laranja vs xilol & -0.800 & 5.745 & s $\quad \mathrm{P}<0.01$ \\
Laranja vs clorofórmio & 0.500 & 3.591 & ns $P>0.05$ \\
Laranja vs halotano & 0.500 & 3.591 & ns $P>0.05$ \\
Eucaliptol vs xilol & -1.280 & 9.192 & s $P<0.001$ \\
Eucaliptol vs clorofórmio & 0.020 & 0.143 & ns $P>0.05$ \\
Eucaliptol vs halotano & 0.020 & 0.143 & ns $P>0.05$ \\
Xilol vs clorofórmio & 1.300 & 9.335 & s $P<0.001$ \\
Xilol vs halotano & 1.300 & 9.335 & s $P<0.001$ \\
Clorofórmio vs halotano & 0.000 & 0.000 & ns $P>0.05$ \\
\hline
\end{tabular}

$\mathrm{s}=$ significante e $\mathrm{ns}=$ não significante $($ Valor de $\mathrm{q}>3.993$ significa 0 valor de $\mathrm{p}<0.05$ )

Tabela 5.7 - Teste de comparação múltipla Tukey-Kramer, período de 10 minutos e concentração de $25 \%$

\begin{tabular}{l|c|c|c}
\hline comparação & diferença da média & $\mathbf{q}$ & Valor de $\mathbf{p}$ \\
\hline Laranja vs eucaliptol & 0.060 & 1.732 & ns $P>0.05$ \\
Laranja vs xilol & -0.400 & 11.547 & s $\mathrm{P}<0.001$ \\
Laranja vs clorofórmio & 0.060 & 1.732 & ns $\mathrm{P}>0.05$ \\
Laranja vs halotano & 0.060 & 1.732 & ns $\mathrm{P}>0.05$ \\
Eucaliptol vs xilol & -0.460 & 13.279 & $\mathrm{~s} \quad \mathrm{P}<0.001$ \\
Eucaliptol vs clorofórmio & 0.000 & 0.000 & $\mathrm{~ns} \mathrm{P}>0.05$ \\
Eucaliptol vs halotano & 0.000 & 0.000 & $\mathrm{~ns} \mathrm{P}>0.05$ \\
Xilol vs clorofórmio & 0.460 & 13.279 & $\mathrm{~s} \mathrm{P}<0.001$ \\
Xilol vs halotano & 0.460 & 13.279 & $\mathrm{~s} \mathrm{P}<0.001$ \\
Clorofórmio vs halotano & 0.000 & 0.000 & $\mathrm{~ns} \mathrm{P}>0.05$ \\
\hline
\end{tabular}

$\mathrm{s}=$ significante e $\mathrm{ns}=$ não significante $($ Valor de $\mathrm{q}>4.654$ significa $o$ valor de $\mathrm{p}<0.05)$ 
Etapa 2.b Tratamento no período de 15 minutos

Os valores da média \pm desvio padrão estão descritos em número de células viáveis na Tabela 5.8 e na Figura 5.5. As Tabelas de An.B6 àAn.B10 mostram os valores originais correspondentes ao número de células viáveis $\left(\mathrm{X} 10^{4}\right)$ nos diferentes grupos experimentais.

Tabela 5.8 - Valores da média \pm desvio padrão correspondentes ao número de células viáveis $\left(\times 10^{4}\right)$ quando da exposição aos solventes, nas concentrações de 10 e 25\%, para o tempo de 15 minutos. $\mathrm{n}=$ número de poços com células, utilizados para o tratamento

\begin{tabular}{c|c|c|c}
\hline Concentração & 0 & 10 & 25 \\
Grupos & 10.58 & 0.08 & 0.08 \\
\hline Óleo de laranja & $( \pm 1.12)$ & $( \pm 0.07)$ & $( \pm 0.09)$ \\
Eucaliptol & 9.45 & 0 & 0 \\
$\mathrm{n}=12$ & $( \pm 0.28)$ & 0.48 & 0.21 \\
Xilol & 10.18 & $( \pm 0.12)$ & $( \pm 0.07)$ \\
$\mathrm{n}=12$ & $( \pm 0.37)$ & 0 & 0 \\
Clorofórmio & 10.33 & & 0 \\
$\mathrm{n}=12$ & $( \pm 1.04)$ & 0 & \\
Halotano & 10.18 & $( \pm 0.46)$ & \\
$\mathrm{n}=12$ & & & 0 \\
\hline
\end{tabular}


A Tabela 5.8 apresenta os valores após a exposição aos solventes no período de 15 minutos, nas concentrações de 10 e $25 \%$, onde podemos observar que os grupos tratados com eucaliptol, clorofórmio e halotano mostraram $100 \%$ de morte celular, em ambas as concentrações estudadas, demonstrando ser extremamente citotóxicos, como podemos observar na Figura 5.5. 


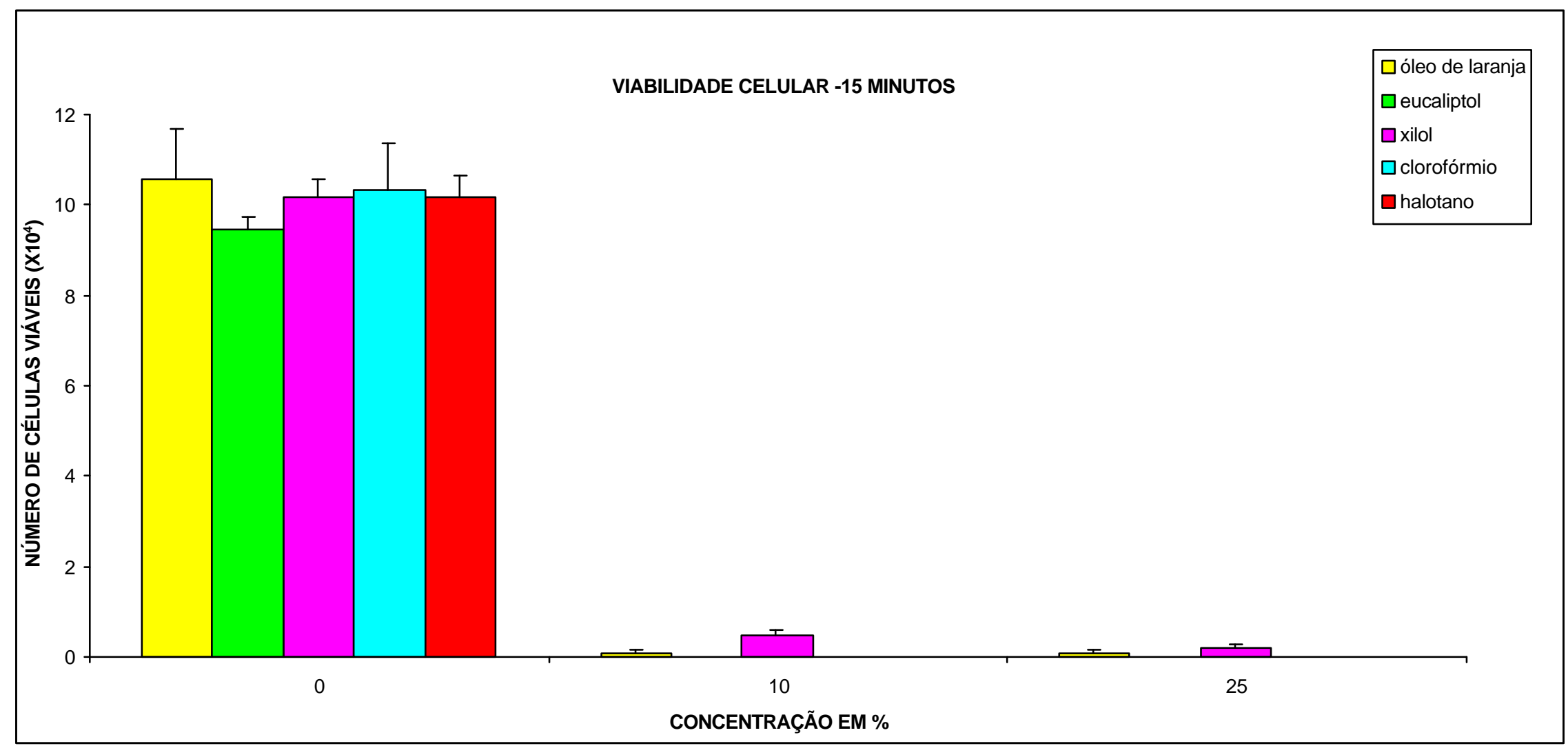

Figura 5.5 - Viabilidade celular quando da exposição aos solventes nas concentrações de 0,10 e $25 \%$ para o períodode 15 minutos. A concentração $0 \%$ corresponde ao grupo controle com número de células no momento do tratamento 


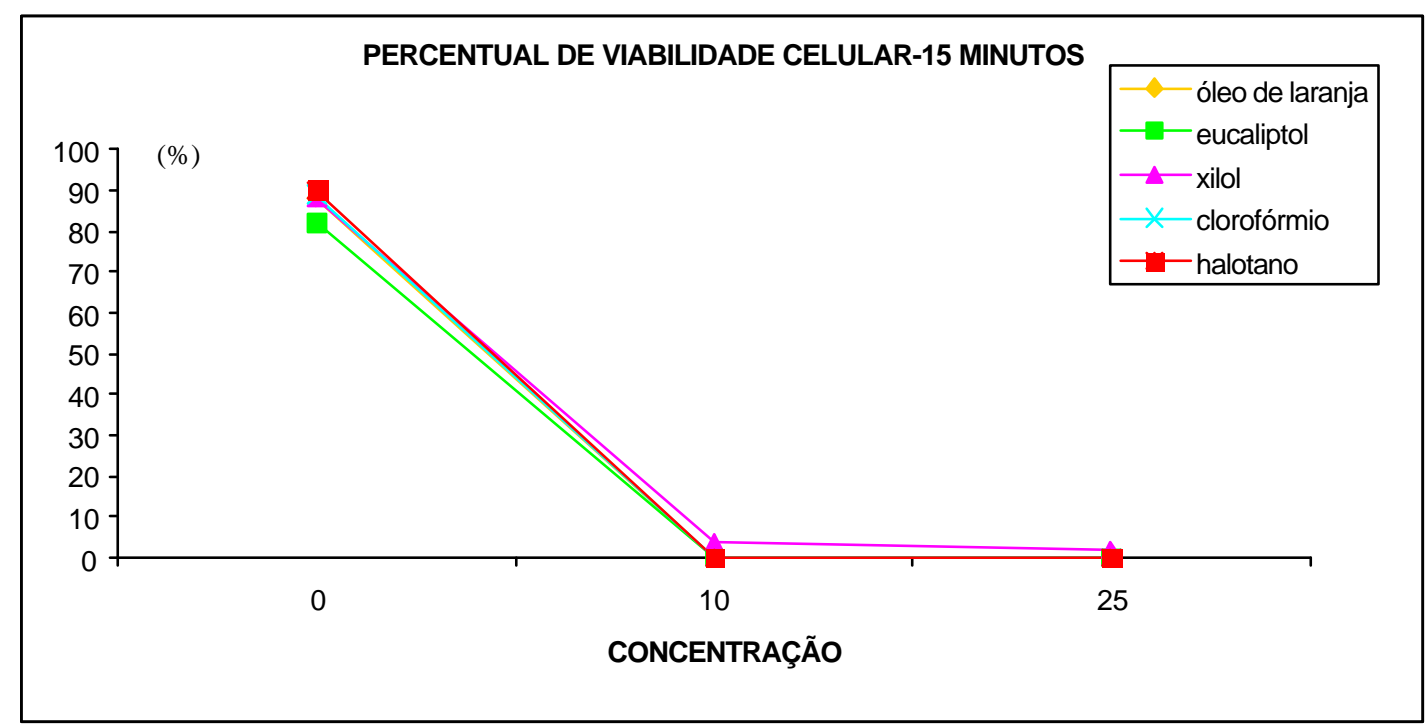

Figura 5.6 - Gráfico com as curvas dos valores correspondentes a porcentagem das células viáveis após a exposição de 15 minutos nas concentrações de 0, 10 e $25 \%$ dos solventes estudados

A Figura 5.6 nos mostra uma queda acentuada no percentual de viabilidade celular em todos os grupos experimentais, após 15 minutos de tratamento. Demonstrando extrema citotoxicidade celular nesse tempo e concentrações estudados.

$\mathrm{Na}$ concentração de $10 \%$ observamos que todos os solventes mostraram diferenças no percentual de número de células em relação ao solvente xilol como podemos observar na Figura 5.6. A Tabela 5.9 nos mostra que existe diferença estatisticamente significante. Já na concentração de $25 \%$ o xilol e o óleo de laranja apresentaram percentual de células viáveis, porém somente o xilol mostrou diferença estatisticamente significante como podemos observar pela Tabela 5.10. Demonstrando que o xilol foi menos citotóxico de todos os solventes estudados nesta concentração e tempo. 
Tabela 5.9 - Teste de comparação múltipla Tukey-Kramer, período de 15 minutos e concentração de $10 \%$

\begin{tabular}{l|c|c|c}
\hline Comparação & diferença da média & $\mathbf{q}$ & Valor de $\mathbf{p}$ \\
\hline Laranja vs eucaliptol & 0.080 & 2.230 & ns $P>0.05$ \\
Laranja vs xilol & -0.400 & 11.151 & s $P<0.001$ \\
Laranja vs clorofórmio & 0.080 & 2.230 & ns $P>0.05$ \\
Laranja vs halotano & 0.080 & 2.230 & ns $P>0.05$ \\
Eucaliptol vs xilol & -0.480 & 13.382 & s $P<0.001$ \\
Eucaliptol vs clorofórmio & 0.000 & 0.000 & ns $P>0.05$ \\
Eucaliptol vs halotano & 0.000 & 0.000 & ns $P>0.05$ \\
Xilol vs clorofórmio & 0.480 & 13.382 & s $P<0.001$ \\
Xilol vs halotano & 0.480 & 13.382 & s $P<0.001$ \\
Clorofórmio vs halotano & 0.000 & 0.000 & ns $P>0.05$ \\
\hline
\end{tabular}

$\mathrm{s}=$ significante e $\mathrm{ns}=$ não significante $($ Valor de $\mathrm{q}>4.654$ significa o valor de $p<0.05$ )

Tabela 5.10 - Teste de comparação múltipla Tukey-Kramer, período de 15 minutos e concentração de $25 \%$

\begin{tabular}{l|c|c|c}
\hline Comparação & diferença da média & $\mathbf{q}$ & Valor de $\mathbf{p}$ \\
\hline Laranja vs eucaliptol & 0.080 & 2.717 & ns $P>0.05$ \\
Laranja vs xilol & -0.130 & 4.416 & ns $P>0.05$ \\
Laranja vs clorofórmio & 0.080 & 2.717 & ns $P>0.05$ \\
Laranja vs halotano & 0.080 & 2.717 & ns $P>0.05$ \\
Eucaliptol vs xilol & -0.210 & 7.133 & s $P<0.01$ \\
Eucaliptol vs clorofórmio & 0.000 & 0.000 & ns $P>0.05$ \\
Eucaliptol vs halotano & 0.000 & 0.000 & ns $P>0.05$ \\
Xilol vs clorofórmio & 0.210 & 7.133 & s $P<0.01$ \\
Xilol vs halotano & 0.210 & 7.133 & s $P<0.01$ \\
Clorofórmio vs halotano & 0.000 & 0.000 & ns $P>0.05$ \\
\hline
\end{tabular}

$\mathrm{s}=$ significante e $\mathrm{ns}=$ não significante $($ Valor de $\mathrm{q}>4.654$ significa $o$ valor de $p<0.05$ ) 
Etapa 3 - Contato direto e indireto, com concentração final de 0, 5 e $10 \%$, para o tempo de 5 minutos

Os valores da média \pm desvio padrão estão descritos em número de células viáveis na Tabela 5.11 e na Figura 5.7. As Tabelas de An.C1 à An.C5 mostram os valores originais correspondentes ao número de células viáveis $\left(\mathrm{X} 10^{4}\right)$ nos diferentes grupos experimentais.

Tabela 5.11 - Valores da média \pm desvio padrão correspondentes ao número de células viáveis $\left(\times 10^{4}\right)$ quando da exposição aos solventes testados, analisados em formas de contato direto e indireto, nas concentrações de 0, 5 e 10\% para o período de 5 minutos. $\mathrm{n}=$ número de poços com células, utilizados para 0 tratamento

\begin{tabular}{|c|c|c|c|c|c|c|}
\hline \multirow[t]{2}{*}{ concentração } & \multicolumn{2}{|c|}{0} & \multicolumn{2}{|c|}{5} & \multicolumn{2}{|r|}{10} \\
\hline & $\begin{array}{l}\text { contato } \\
\text { direto }\end{array}$ & $\begin{array}{l}\text { contato } \\
\text { indireto }\end{array}$ & $\begin{array}{l}\text { contato } \\
\text { direto }\end{array}$ & $\begin{array}{l}\text { contato } \\
\text { indireto }\end{array}$ & $\begin{array}{c}\text { contato } \\
\text { direto }\end{array}$ & $\begin{array}{l}\text { contato } \\
\text { indireto }\end{array}$ \\
\hline Óleo de laranja & 8.75 & 9.31 & 1.35 & 4.75 & 0.37 & 1.06 \\
\hline$n=12$ & $( \pm 0.69)$ & $( \pm 0.41)$ & $( \pm 0.24)$ & $( \pm 0.78)$ & $( \pm 0.2)$ & $( \pm 0.16)$ \\
\hline Eucaliptol & 8.75 & 9.31 & 0.12 & 0.41 & 0 & 0 \\
\hline $\mathrm{n}=12$ & $( \pm 0.69)$ & $( \pm 0.41)$ & $( \pm 0.20)$ & $( \pm 0.40)$ & & \\
\hline Xilol & 8.75 & 9.31 & 0 & 3.81 & 0 & 1.70 \\
\hline $\mathrm{n}=12$ & $( \pm 0.69)$ & $( \pm 0.41)$ & & $( \pm 0.70)$ & & $( \pm 0.20)$ \\
\hline Clorofórmio & 8.75 & 9.31 & 0 & 0.07 & 0 & 0 \\
\hline$n=12$ & $( \pm 0.69)$ & $( \pm 0.41)$ & & $( \pm 0.16)$ & & \\
\hline Halotano & 8.75 & 9.31 & 0 & 0.7 & 0 & 0 \\
\hline$n=12$ & $( \pm 0.69)$ & $( \pm 0.41)$ & & $( \pm 0.58)$ & & \\
\hline
\end{tabular}


A Tabela 5.11 representa os valores da média \pm desvio padrão quando os solventes foram colocados em contato direto e indireto com as células de fibroblastos e nos revelou que a forma de contato dos diferentes grupos experimentais alterou o número de células viáveis. Quando os solventes foram colocados em contato direto com as células ocorreu uma diminuição acentuada nas médias de número de células viáveis. Nos grupos tratados com xilol, clorofórmio e halotano ocorreram 100\% de morte celular, em 5 minutos, independente da concentração utilizada. O óleo de laranja e o xilol mostraram ser menos citotóxicos em relação aos outros grupos quando o contato foi indireto.

A Figura 5.7 mostra o gráfico com os valores de média \pm desvio padrão dos grupos com o tratamento sobre as células em formas de contato direto e indireto. Podemos observar que o óleo de laranja e o xilol apresentaram número de células viáveis maiores em relação aos demais grupos experimentais, quando o contato foi indireto.

$\mathrm{Na}$ concentração de $5 \%$ todos os solventes apresentaram células viáveis quando o contato foi indireto, porém quando o contato foi direto ocorreu queda drástica no número de células viáveis. Já na concentração de 10\%, o óleo de laranja e o xilol mostraram células viáveis em relação aos demais grupos, quando o contato foi indireto como podemos observar na Tabela 5.11.

Quando o contato foi direto, somente óleo de laranja apresentou viabilidade celular, na concentração de $10 \%$, embora não tenha mostrado 
ser significantemente diferente dos demais solventes como podemos verificar pela Tabela 5.13 . 


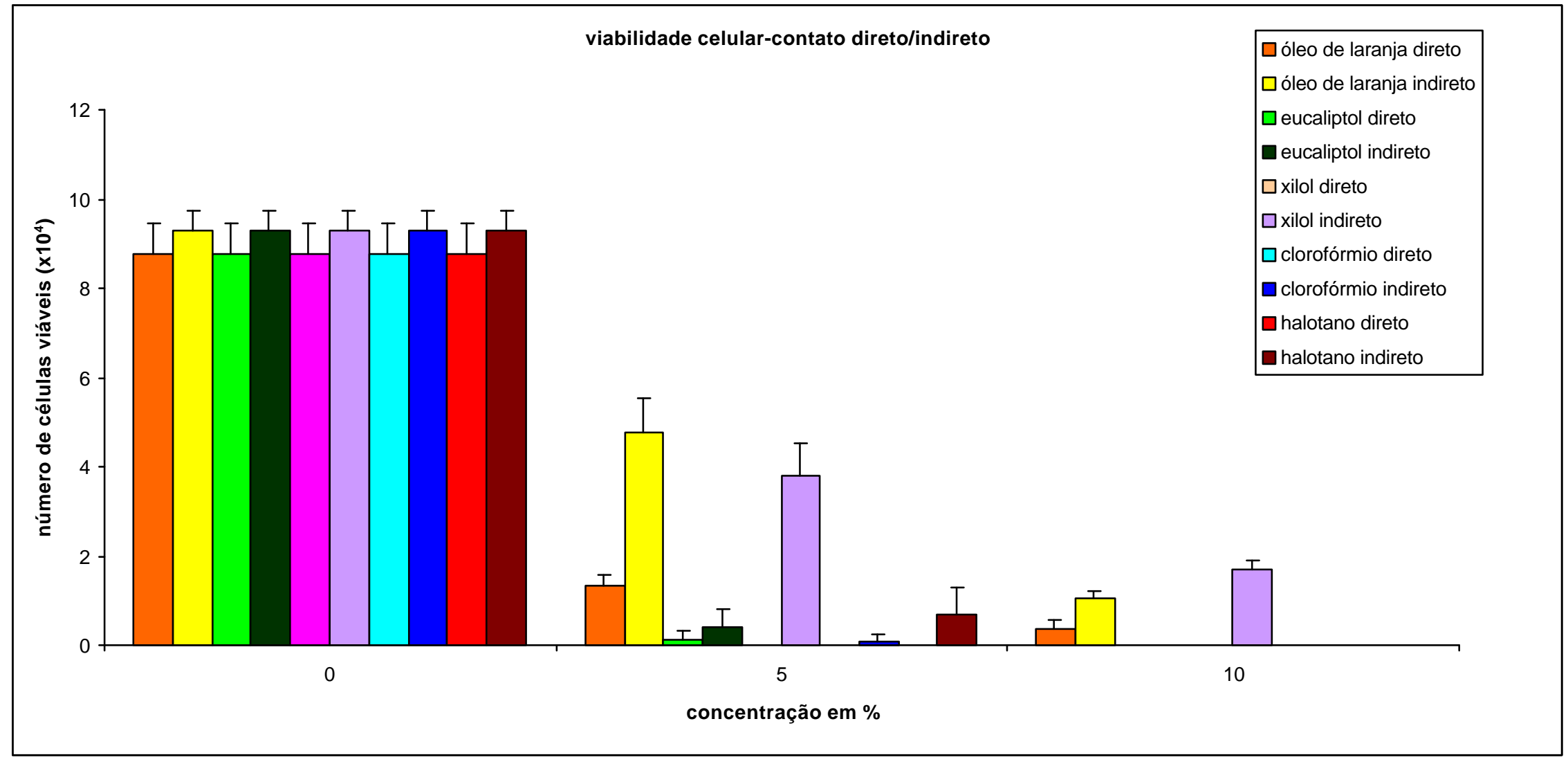

Figura 5.7 -Viabilidade celular quando da exposição direta ou indireta dos solventes sobre as células em cultura, nas concentrações de 0,5 e 10\% no período de 5 minutos. A concentração $0 \%$ corresponde ao grupo controle com número de células no momento do tratamento 


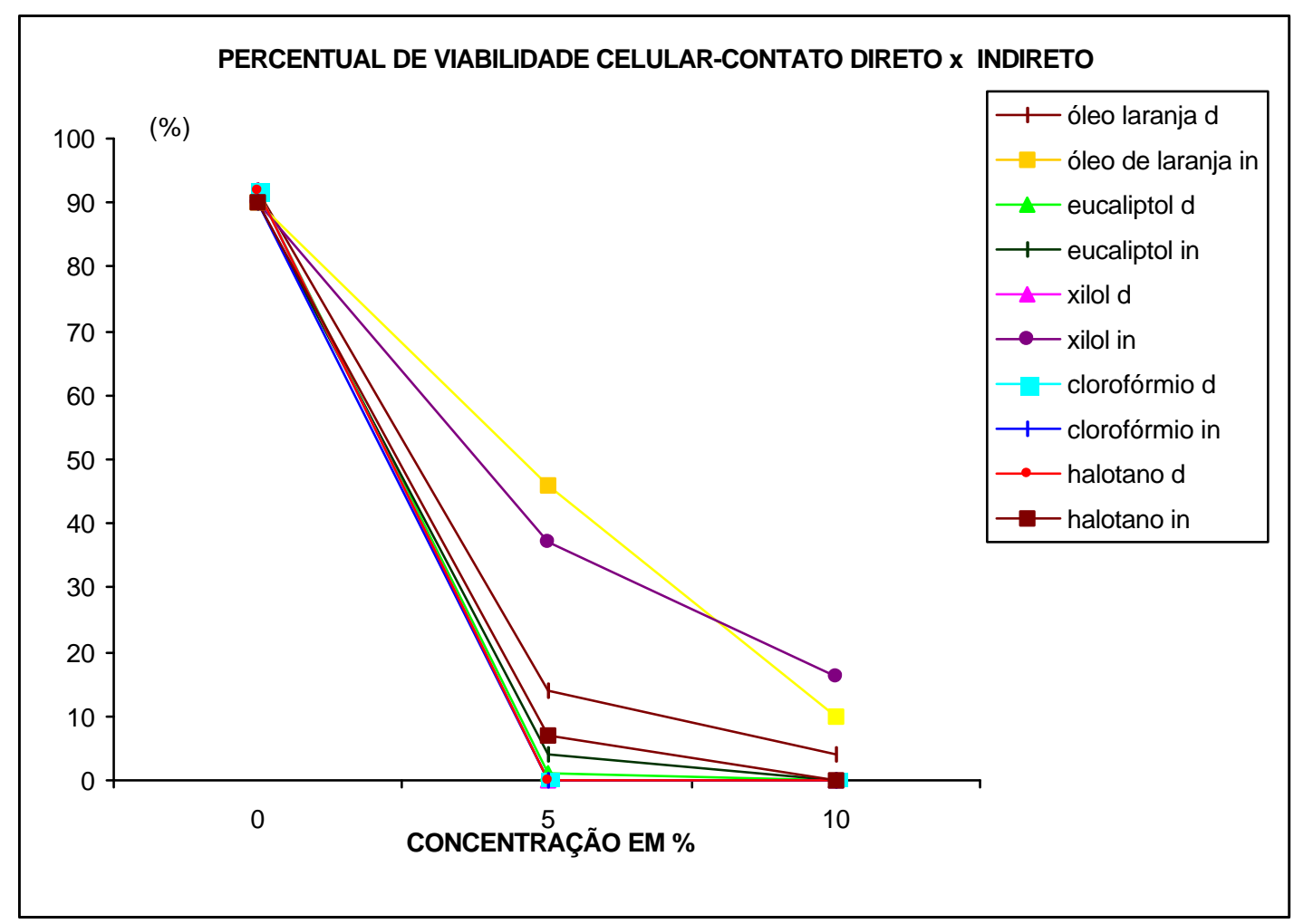

Figura 5.8 - Gráfico com as curvas dos valores correspondentes a porcentagem das células viáveis após a exposição de 5 minutos nas concentrações de 0, 5 e $10 \%$ dos solventes estudados em contato direto e indireto

Ao observarmos a Figura 5.8 verificamos que o óleo de laranja, contato direto e indireto, e xilol, contato indireto, mostraram diferenças no percentual de células viáveis em relação aos demais solventes. E a análise dos dados apresentados nas Tabelas 5.12 e 5.13 revelou que a diferença foi estatisticamente significante em relação aos demais solventes e entre eles também, quando a concentração foi de $5 \%$. Já na concentração de $10 \%$ e em contato indireto, o óleo de laranja e o xilol mostraram diferenças no percentual de células viáveis que também foram estatisticamente significantes. Portanto, observamos que quando a concentração foi 5\%, o 
óleo de laranja em contato indireto foi o menos citotóxicos de todos os grupos estudados, seguidos pelo xilol no contato indireto. Na concentração de $10 \%$ o menos citotóxico foi xilol em contato indireto seguido pelo óleo de laranja em contato indireto.

O eucaliptol, xilol, clorofórmio e halotano, em contato direto, mostraram ser muito citotóxicos.

Tabela 5.12 - Teste de comparação múltipla Tukey-Kramer, período de 5 minutos e concentração de 5\%. Formas de contato direto ou indireto sobre as células em cultura

\begin{tabular}{|c|c|c|c|}
\hline Comparação & diferença da média & q & Valor de $p$ \\
\hline Laranja d vs laranja in & -3.400 & 39.005 & $P<0.001$ \\
\hline Laranja d vs eucaliptol d & 1.230 & 14.111 & $P<0.001$ \\
\hline Laranja d vs xilol $d$ & 1.350 & 15.487 & $P<0.001$ \\
\hline Laranja d vs clorofórmio $d$ & 1.350 & 15.487 & $P<0.001$ \\
\hline Laranja d vs halotano d & 1.350 & 15.487 & $P<0.001$ \\
\hline Laranja in vs eucaliptol in & 4.340 & 49.789 & $P<0.001$ \\
\hline Laranja in vs xilol in & 0.940 & 10.784 & $P<0.001$ \\
\hline Laranja in vs clorofórmio in & 4.680 & 53.689 & s $\quad P<0.001$ \\
\hline Laranja in vs halotano in & 4.050 & 46.462 & s $\quad P<0.001$ \\
\hline Eucaliptol d vs eucalyptol in & -0.290 & 3.327 & ns $P>0.05$ \\
\hline Eucaliptol d vs xilol d & 0.120 & 1.377 & ns $\quad P>0.05$ \\
\hline Eucaliptol d vs clorofórmio d & 0.120 & 1.377 & ns $\quad P>0.05$ \\
\hline Eucaliptol d vs halotano d & 0.120 & 1.377 & ns $\quad P>0.05$ \\
\hline Eucaliptol in vs xilol in & -3.400 & 39.005 & s $\quad P<0.001$ \\
\hline Eucaliptol in vs clorofórmio in & 0.340 & 3.900 & ns $\quad P>0.05$ \\
\hline Eucaliptol in vs halotano in & -0.290 & 3.327 & ns $\quad P>0.05$ \\
\hline Xilol d vs xilol in & -3.810 & 43.708 & s $\quad P<0.001$ \\
\hline Xilol d vs clorofórmio d & 0.000 & 0.000 & ns $\quad P>0.05$ \\
\hline Xilol d vs halotano d & 0.000 & 0.000 & ns $\quad P>0.05$ \\
\hline Xilol in vs clorofórmio in & 3.740 & 42.905 & s $\quad P<0.001$ \\
\hline Xilol in vs halotano in & 3.110 & 35.678 & s $\quad P<0.001$ \\
\hline Clorofórmio d vs clorofórmio in & -0.070 & 0.803 & ns $\quad P>0.05$ \\
\hline Clorofórmio d vs halotano d & 0.000 & 0.000 & ns $\quad P>0.05$ \\
\hline Clorofórmio in vs halotano in & -0.630 & 7.227 & s $\quad P<0.001$ \\
\hline Halotano d vs halotano in & -0.700 & 8.030 & s $P<0.001$ \\
\hline
\end{tabular}

$\mathrm{d}=$ contato direto, in=contato indireto, $\mathrm{s}=$ significante e $\mathrm{ns}=$ não significante. (valor de $\mathrm{q}>5.096$ significa que o valor de $p<0.05$ ) 
Tabela 5.13 - Teste de comparação múltipla Tukey-Kramer, período de 5 minutos e concentração de $10 \%$. Formas de contato direto ou indireto sobre as células em cultura

\begin{tabular}{|c|c|c|c|}
\hline Comparação & diferença da média & $q$ & Valor de $p$ \\
\hline Laranja d vs laranja in & -0.690 & 7.916 & s $\quad P<0.001$ \\
\hline Laranja d vs eucaliptol $d$ & 0.370 & 4.245 & ns $\quad P>0.05$ \\
\hline Laranja d vs xilol d & 0.370 & 4.245 & ns $\quad P>0.05$ \\
\hline Laranja d vs clorofórmio d & 0.370 & 4.245 & ns $\quad P>0.05$ \\
\hline Laranja d vs halotano d & 0.370 & 4.245 & ns $\quad P>0.05$ \\
\hline Laranja in vs eucaliptol in & 1.060 & 12.160 & s $\quad P<0.001$ \\
\hline Laranja in vs xilol in & -0.640 & 7.342 & s $\quad P<0.001$ \\
\hline Laranja in vs clorofórmio in & 1.060 & 12.160 & s $\quad P<0.001$ \\
\hline Laranja in vs halotano in & 1.060 & 12.160 & s $\quad P<0.001$ \\
\hline Eucaliptol d vs eucalyptol in & 0.000 & 0.000 & ns $\quad P>0.05$ \\
\hline Eucaliptol d vs xilol d & 0.000 & 0.000 & ns $\quad P>0.05$ \\
\hline Eucaliptol d vs clorofórmio d & 0.000 & 0.000 & ns $P>0.05$ \\
\hline Eucaliptol d vs halotano $d$ & 0.000 & 0.000 & ns $\quad P>0.05$ \\
\hline Eucaliptol in vs xilol in & -1.700 & 19.502 & s $\quad P<0.001$ \\
\hline Eucaliptol in vs clorofórmio in & 0.000 & 0.000 & ns $P>0.05$ \\
\hline Eucaliptol in vs halotano in & 0.000 & 0.000 & ns $\quad P>0.05$ \\
\hline Xilol d vs xilol in & -1.700 & 19.502 & s $P<0.001$ \\
\hline Xilol d vs clorofórmio d & 0.000 & 0.000 & ns $\quad P>0.05$ \\
\hline Xilol d vs halotano d & 0.000 & 0.000 & ns $P>0.05$ \\
\hline Xilol in vs clorofórmio in & 1.700 & 19.502 & s $P<0.001$ \\
\hline Xilol in vs halotano in & 1.700 & 19.502 & s $\quad P<0.001$ \\
\hline Clorofórmio d vs clorofórmio in & 0.000 & 0.000 & ns $\quad P>0.05$ \\
\hline Clorofórmio d vs halotano d & 0.000 & 0.000 & ns $P>0.05$ \\
\hline Clorofórmio in vs halotano in & 0.000 & 0.000 & ns $\quad P>0.05$ \\
\hline Halotano d vs halotano in & 0.000 & 0.000 & ns $\quad P>0.05$ \\
\hline
\end{tabular}




\section{Etapa 4 - Solvente / álcool (1:1), diluição final no meio de cultura de 5\%, para o tempo de 5 minutos}

Os solventes foram previamente solubilizados em álcool absoluto na proporção de 1:1, com concentração final de 5\% em meio de cultura.

Com o intuito de avaliar se o preparo prévio da substância a ser testada, poderia promover alguma alteração na viabilidade celular, além da mensuração de número de células viáveis, com os solventes utilizados em retratamento endodôntico na forma como são utilizados na prática clínica, realizamos ainda a solubilização de todos os solventes em álcool absoluto para torná-los substâncias homogêneas e miscíveis em meio de cultura. As médias \pm desvio padrão referentes a estas medidas estão representadas na Tabela 5.14 e na Figura 5.9.

Antes da análise dos resultados é importante salientar que o grupo controle corresponde ao grupo tratado com o álcool absoluto, que foi 0 veículo utilizado na preparação dos diferentes solventes.

A Tabela 5.14 nos mostra pequeno número de células viáveis nos grupos óleo de laranja e eucaliptol, enquanto o xilol, clorofórmio e halotano mostraram $100 \%$ de morte celular. No grupo controle pode-se observar que 77\% de células estavam vitais, isto significa que o álcool absoluto, na proporção utilizada para solubilizar os solventes, pode manter as células viáveis e permitiu o estudo comparativo entre os solventes. 
Tabela 5.14 - Valores da média \pm desvio padrão correspondentes ao número de células viáveis $\left(\times 10^{4}\right)$ quando da exposição aos solventes testados, na concentração de $5 \%$ para o período de 5 minutos, os solventes foram previamente solubilizados em álcool absoluto. $\mathrm{n}=$ número de poços com células, utilizados para o tratamento. Controle corresponde ao grupo com a mesma proporção de álcool absoluto utilizado para solubilizar os solventes

\begin{tabular}{c|c}
\hline Concentração & 5 \\
\hline Orupos & 1.42 \\
Eucaliptol & $( \pm 0.06)$ \\
$n=12$ & 0.15 \\
Xilol & $( \pm 0.12)$ \\
$n=12$ & 0 \\
Clorofórmio & \\
$n=12$ & 0 \\
Halotano & \\
$n=12$ & 0 \\
Controle & \\
$n=12$ & $( \pm 1.14)$ \\
\hline
\end{tabular}




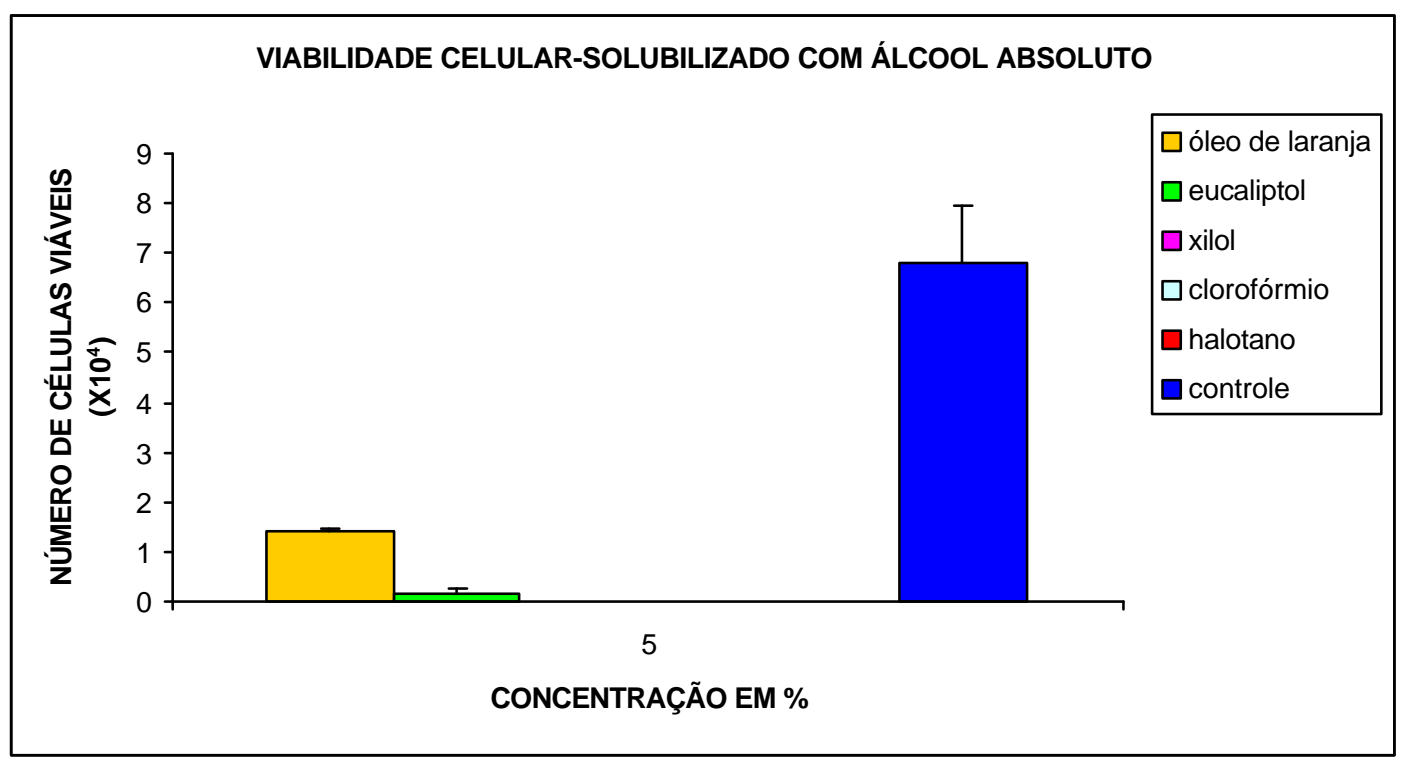

Figura 5.9 - Gráfico que representa os valores da média \pm desvio padrão do número de células viáveis dos solventes testados na concentração de $5 \%$ para o período de 5 minutos, os solventes foram previamente solubilizados em álcool absoluto

Pela Figura 5.9 podemos observar que os grupos experimentais apresentam diferenças na média de número de células viáveis em relação ao grupo controle. O eucaliptol, xilol, clorofórmio e halotano apresentaram diferenças estatisticamente significantes quando comparados ao óleo de laranja e todos os solventes estudados mostraram diferenças significantes em relação ao controle como podemos verificar na Tabela 5.15. O álcool absoluto foi menos citotóxico que os solventes estudados seguido pelo óleo de laranja e eucaliptol. 
Tabela 5.15 - Teste de comparação múltipla Tukey-Kramer, período de 5 minutos e concentração de $5 \%$, solventes previamente solubilizados em álcool absoluto

\begin{tabular}{l|c|c|c}
\hline comparação & diferença da média & $\mathbf{q}$ & Valor de $\mathbf{p}$ \\
\hline Laranja vs eucaliptol & 1.270 & 9.388 & s $\mathrm{P}<0.001$ \\
Laranja vs xilol & 1.420 & 10.497 & $\mathrm{~s} \quad \mathrm{P}<0.001$ \\
Laranja vs clorofórmio & 1.420 & 10.497 & $\mathrm{~s} \mathrm{P}<0.001$ \\
Laranja vs halotano & 1.420 & 10.497 & $\mathrm{~s} \quad \mathrm{P}<0.001$ \\
Laranja vs controle & -5.380 & 39.770 & $\mathrm{~s} \mathrm{P}<0.001$ \\
Eucaliptol vs xilol & 0.150 & 1.109 & $\mathrm{~ns} \mathrm{P}>0.05$ \\
Eucaliptol vs clorofórmio & 0.150 & 1.109 & $\mathrm{~ns} \mathrm{P}>0.05$ \\
Eucaliptol vs halotano & 0.150 & 1.109 & $\mathrm{~ns} \mathrm{P}>0.05$ \\
Eucaliptol vs controle & -6.650 & 49.158 & $\mathrm{~s} \mathrm{P}<0.001$ \\
Xilol vs clorofórmio & 0.000 & 0.000 & $\mathrm{~ns} \mathrm{P}>0.05$ \\
Xilol vs halotano & 0.000 & 0.000 & $\mathrm{~ns} \mathrm{P}>0.05$ \\
Xilol vs controle & -6.800 & 50.267 & $\mathrm{~s} \mathrm{P}<0.001$ \\
Clorofórmio vs halotano & 0.000 & 0.000 & $\mathrm{~ns} \mathrm{P}>0.05$ \\
Clorofórmio vs controle & -6.800 & 50.267 & $\mathrm{~s} \mathrm{P}<0.001$ \\
Halotano vs controle & -6.800 & 50.267 & $\mathrm{~s} \mathrm{P}<0.001$ \\
\hline S=significante e ns= não significante (valor de q $>4.156$ significa que o valor de $\mathrm{P}<0.05)$
\end{tabular}

A Tabela An.D mostra os valores originais correspondentes ao número de células viáveis $\left(\times 10^{4}\right)$ no diferentes grupos experimentais.

A solubilização dos solventes em álcool absoluto provocou alteração no número de células viáveis e colocou em discussão a importância da forma como as substâncias são preparadas antes do estudo comparativo de citotoxicidade. Como podemos observar os resultados, quando os solventes foram preparados previamente, divergiram quando comparados aos dados da Tabela 5.1, na coluna onde mostrou a concentração de $5 \%$ dos solventes estudados. Sugerindo que o xilol foi menos citotóxico pelos dados da etapa 
experimental 1 e o resultado após o preparo prévio, etapa experimental 4, nos mostrou que o óleo de laranja foi menos citotóxico.

Após a análise de todas as etapas experimentais pudemos verificar que a forma de contato e o preparo prévio dos solventes alteraram significantemente o número de células viáveis, como podemos ver na Tabela 5. 16 .

Tabela 5.16 - Percentual de número de células viáveis quando da exposição aos solventes testados, em diferentes etapas experimentais, na concentração de $5 \%$ para o período de 5 minutos

\begin{tabular}{c|c|c|c|c}
$\begin{array}{r}\text { Etapas } \\
\text { Experimentais }\end{array}$ & $\begin{array}{c}\mathbf{1} \\
\text { adicionado ao } \\
\text { meio de cultura }\end{array}$ & $\begin{array}{c}3 \mathbf{b} \\
\text { contato } \\
\text { direto }\end{array}$ & $\begin{array}{c}\mathbf{4} \\
\text { contato } \\
\text { indireto }\end{array}$ & $\begin{array}{c}\text { solubilizado com } \\
\text { álcool absoluto }\end{array}$ \\
\hline $\begin{array}{c}\text { Óleo da casca de laranja } \\
\text { Eucaliptol }\end{array}$ & 26 & 15 & 51 & 16.3 \\
Xilol & 1 & 1 & 4 & 0.37 \\
Clorofórmio & 29 & 0 & 40 & 0 \\
Halotano & 0 & 0 & 0 & 0 \\
\hline
\end{tabular}

A Tabela 5.16 mostra que a forma de contato e o preparo prévio do material puderam alterar acentuadamente o percentual de viabilidade celular em aproximadamente $50 \%$ como ocorreu com o óleo de laranja (etapa 1 vs etapa 3b) e em $40 \%$ com o xilol (etapa 3a vs etapa 3b). Sugerindo a importância do preparo do material antes dos testes de citotoxicidade. 


\section{DISCUSSÃO}

O retratamento endodôntico consiste na realização de um novo tratamento, seja porque o anterior fracassou ou porque se deseja fazer um tratamento mais correto ou adequado, principalmente nos casos em que surgiu a necessidade dos elementos dentários servirem de suporte a trabalhos protéticos (Gilbert \& Rice, 1987; Lopes et al., 1999).

Apesar da endodontia contemporânea, respaldada no desenvolvimento científico e no aprimoramento técnico das manobras que Ihe são próprias, vir alcançando altos índices de sucesso, recentemente tem aumentado consideravelmente o número de casos caracterizados por uma sintomatologia incompatível com a reparação tecidual, demonstrando falha do tratamento endodôntico realizado (Berger, 1998).

Neste sentido, alguns estudos têm mostrado que o retratamento do insucesso tornou-se necessário para preservação do dente. A manipulação bem sucedida desta etapa operatória depende de uma compreensão das diferenças existentes do tratamento inicial, diagnóstico e plano de tratamento bem traçado e domínio das técnicas dessa nova intervenção (Taintor et al., 1983; Friedman \& Stabholz, 1986; Stabholz \& Friedman, 1988; Friedman et 
al., 1990; Costa \& Antoniazzi, 1992; Gutmann et al., 1997; Lopes et al., 1999).

Independentemente da técnica empregada durante a remoção do material obturador, o importante nesse momento é não criar iatrogenias que possam dificultar ou impedir a reinstrumentação do canal radicular. Contudo, é importante ressaltar que as alterações podem ocorrer devido àresistência que o material obturador como a guta-percha e o cimento exercem na penetração do instrumento para acessar as proximidades do forame apical do dente (Friedman et al., 1990).

Tentando minimizar esses riscos, vários solventes orgânicos de guta percha foram testados e pesquisados. Entre os mais conhecidos ainda são o clorofórmio, xilol e o eucaliptol. O clorofórmio apresenta-se como um líquido pesado, transparente, incolor e de odor característico. É pouco solúvel na água e inteiramente miscível com o álcool. Altera-se pela luz e pelo ar. Atualmente, a utilização deste produto é bastante polêmica, devido a relatos de toxicidade e potencial carcinogênico (Torkelson et al., 1976; Wilcox et al., 1987; Wennberg \& Orstavik, 1989; McDonald \& Vire, 1992; Zakariasen et al., 1990; Wourms et al., 1990).

O xilol, por sua vez, apresenta-se como um líquido límpido, incolor, com odor semelhante ao benzeno. É insolúvel na água, porém solúvel em álcool e no benzeno. Podendo causar irritação à mucosa gástrica, convulsão, insônia, excitamento e depressão do SNC por contato e inalação (The Condensed Chemical Dictionary, 1966; The Merck Index, 1989; Pécora et al., 1993; Dorland's illustrated medical dictionary, 1994). 
O eucaliptol apresenta-se como um líquido incolor e de odor aromático semelhante ao da cânfora. É insolúvel na água e inteiramente miscível com o álcool, exibe efeito antibacteriano e propriedades antiinflamatórias (The Condensed Chemical Dictionary, 1966; The Merck Index, 1989; Dorland's illustrated medical dictionary, 1994), não sendo um solvente de guta-percha tão eficaz quanto aos demais (Worms et al., 1990; Hunter et al., 1991; Pécora et al., 1992; Görduysus et al., 1997; Oyama et al., 2003).

O óleo de laranja é pouco solúvel em água, porém o é em álcool, sendo utilizado em farmacologia para aromatizar e dar sabor (The Condensed Chemical Dictionary, 1966; The Merck Index, 1989; Dorland's illustrated medical dictionary, 1994). Mostrou ação solvente sobre a gutapercha (Pécora et al., 1992; Pécora, et al., 1993; Spanó et al., 1995; Oyama et al., 2002).

O halotano é um anestésico de uso veterinário, volátil, não inflamável e miscível em álcool (The Condensed Chemical Dictionary, 1966; The Merck Index, 1989; Dorland's illustrated medical dictionary, 1994; Wourms et al., 1990; Hunter et al., 1991; Görduysus et al., 1997). É uma substância que mostrou ser promissor como solvente por apresentar efetividade semelhante ao clorofórmio e xilol, entretanto não relataram estudos referentes à sua toxicidade (Hunter et al., 1991; Wilcox, 1995; Görduysus et al., 1997).

Existem muitos relatos quanto à efetividade dos solventes, porém a literatura é escassa quanto ao estudo de compatibilidade tecidual desses para o uso endodôntico. O autor Hansen, 2001, também compartilhou com a 
idéia discutida. Em 1980, a FDI recomendou a reavaliação de testes de toxicidade quando da alteração na aplicação ou do uso de produtos aceitos previamente para outras finalidades.

Diante disso, a escolha do solvente deve também, ser realizada em concordância com requisito fundamental de um material biologicamente compatível, ou seja, ser bem tolerado pelos tecidos do periápice, não retardando ou impedindo a esperada reparação tecidual (Paiva \& Antoniazzi, 1988; Santos, 1998).

A difusão das medicações através de tecido periapical pode ser um pouco diferente em meio de cultura de células. Sabemos, ainda que, a mesma é, sem dúvida, o meio mais sensível aos efeitos tóxicos das drogas, do que o tecido periapical. Embora, no corpo, as células fagocitárias, circulação linfática e sanguínea ajudariam a diluir e a eliminar a droga permitindo suporte para que as mesmas não sejam tão irritantes clinicamente, como em estudo de citotoxicidade (Vander Wall et al., 1972).

Nas últimas três décadas, o sistema de cultura celular tem atraído atenção de grupo de pesquisadores procurando meios de quantificar efeitos tóxicos (Spangberg \& Conn, 1973; Browne \& Tyas, 1979; Murphy, 1988; Pascon \& Spangberg, 1990; Barbosa et al, 1994; Daniel, 1998; Santos, 1998; Malheiros, 2000; Scelza et al, 2001). Entretanto, os testes têm sido desenvolvidos e modificados por interesses individuais, com o objetivo de encontrar caminhos para expressar potencial tóxico do material dentário. Provavelmente o maior segmento dos artigos vem do campo da Endodontia, onde o contato direto material-tecido faz parte do processo de tratamento. 
Este fato tem levado a muitas questões não resolvidas sobre a citotoxicidade de material e a importância dos resultados comparativo com teste usual in vitro (Spangberg \& Conn, 1978; Hensten-Pettersen, 1988; Schmalz, 1994).

Há de considerar que uma das maiores dificuldades com a avaliação de biomateriais in vitro é entender o teste e interpretar apropriadamente os resultados obtidos. Isto é essencial, pois esses tipos de experimentos têm suas limitações que deveriam ser consideradas (Schmaltz, 1988; Browne, 1988; Spangberg \& Pascon, 1988; Schmalz, 1994).

A imensa maioria das drogas é freqüentemente solúvel em vários sistemas de líquidos, entretanto, sabemos que alguns materiais odontológicos possuem baixa solubilidade. Esta diferença maior representa um problema metodológico e torna necessário o ajuste técnico quando do estudo de citotoxicidade (Spangberg \& Pascon, 1988).

Como vimos anteriormente, a maior objeção desses métodos de citotoxicidade é a eventual não existência de contato direto entre a célula e material teste e com isso a reação se processar de forma bastante lenta. Assim, a validade desses testes foi questionada. Este fato foi comprovado em nosso estudo, ao se comparar o percentual de viabilidade celular em diferentes etapas experimentais, apresentados na Tabela 5.16, quando da análise do percentual de células viáveis na etapa experimental $3 a$ e $3 b$, observou-se que a real existência de contato do solvente-célula reduziu a vida celular nos diferentes grupos experimentais: $71 \%$ no grupo óleo de laranja, $75 \%$ no grupo eucaliptol, $100 \%$ no grupo xilol e halotano quando comparado ao tratamento das células em contato indireto. 
No início a avaliação do dano celular era uma medida subjetiva e o critério para a morte não estava bem definido. Diante disso, Spangberg, em 1973, introduziu um método de contagem de células para avaliação do dano celular e a utilização de lamínula de vidro na câmara de cultura para promover contato direto do material com as células onde aproximava o procedimento de cultura in vitro a um resultado bastante confiável.

Com esse intuito, em nosso experimento, devido æ̀s substâncias estudadas apresentarem-se com densidades diferentes e com pequena solubilidade em meio de cultura, deparamos com a necessidade de pesquisar um método para tornar todas as substâncias solúveis em meio de cultura e procurar uma única substância que pudesse solubilizar todos os solventes ora estudados.

Uma revisão da literatura quanto àsolubilização de materiais mostrou que substâncias como EDTA, polietilenoglicol ou álcool absoluto poderiam ser utilizados para solubilização de materiais para testes de citotoxicidade (Spangberg \& Pascon, 1988). Os pesquisadores Kettering \& Torabinejad (1988) utilizavam apenas álcool para solubilizar os materiais em seus experimentos.

Partindo de tais pesquisas, realizamos testes pilotos utilizando as substâncias acima mencionadas e observamos que o álcool absoluto mostrou resultados melhores e misturas homogêneas. Ainda, Freshney (2000) protocolou utilizar a menor proporção possível de álcool absoluto capaz de solubilizar os materiais a serem testados para que o mesmo permita estudo comparativo de citotoxicidade. 
Por outro lado, alguns estudos mostravam a diluição dos materiaisteste aquosos em meio de cultura até observarem células vitais (Wennberg, 1976; Malheiros, 2000; Scelza et al., 2001) e assim estas substâncias foram diluídas para poder realizar estudo comparativo em curto e longo prazo. No entanto, é do conhecimento de todos que qualquer material estudado mostraria não ser tóxico quando a diluição for extremamente alta, por isso, é importante a interpretação correta dos dados obtidos e a sua correlação na prática clínica.

A revisão de pesquisas desenvolvidas com relação aos estudos de toxicidade de materiais odontológicos inclui líquidos hidrofílicos e hidrofóbicos, semi-sólidos e sólidos. E os resultados, utilizando métodos de cultura celular para avaliar a biocompatibilidade têm demonstrado que qualquer material odontológico pode se mostrar tóxico ou não tóxico, dependendo das condições de teste. Por isso, o mesmo deve ser realizado em condição selecionada simulando situações reais de uso clínico (HenstenPettersen, 1988).

Spangberg \& Pascon (1988) relataram que ao se utilizar soluções testes fluídas, a mistura com as células deve corresponder àrelação de $1 \mathrm{~mL}$ de suspensão celular para $1 \mathrm{~mL}$ de solução teste e a mesma deveria ser normalmente preparada em meio de cultura. Acredita-se ainda, que ao se diluir uma substância, principalmente em um estudo comparativo, quanto maior o distanciamento da substância utilizada das condições de uso clínico, maiores as divergências de resultados, pois envolvem as alterações das características químicas e funcionais. 
No início da parte experimental realizamos testes pilotos com os solventes nos períodos de longo prazo. No entanto observamos que não houve viabilidade celular após o período de 20 minutos. Assim, determinamos os períodos de 5, 10 e 15 minutos para o nosso experimento, tempos estes clinicamente compatíveis durante o retratamento endodôntico, onde se deseja a solubilização da guta-percha.

Na etapa experimental 1, avaliamos as concentrações de $0,5,10,25$, 50 e $100 \%$ para cada solvente com o objetivo de obter uma curva doseresposta. O período de tratamento foi de 5 minutos. As concentrações foram obtidas misturando-se o solvente ao meio de cultura que correspondem à concentração final em meio de cultura, apesar de alguns estudos terem relacionado as diluições de 0,$1 ; 0,01 ; 0,001$, e até $0,0001 \%$, quando das substâncias líquidas (Malheiros, 2000; Scelza et al., 2001).

Nesta etapa procuramos avaliar a viabilidade celular com o aumento da concentração dos solventes. Pudemos constatar, através dos dados da Tabela 5.1, que as médias de número de células decresceram acentuadamente, independentemente do grupo experimental quando a concentração foi de $5 \%$. Nas concentrações de $10,25,50$ e $100 \%$ o eucaliptol, clorofórmio e halotano mostraram $100 \%$ de morte celular.

Os resultados revelaram que a $5 \%$ e $10 \%$ o óleo de laranja e o xilol apresentaram diferenças estatisticamente significantes quando comparados aos demais grupos (Tabelas 5.2 e 5.3 ). E a $25 \%$ todos os solventes mostraram diferenças significativas quanto ao número de células viáveis em 
relação ao xilol, sendo este o menos citotóxico entre os solventes estudados nesta etapa da pesquisa (Tabela 5.4).

É importante salientar que o solvente utilizado, durante 0 procedimento de retratamento, apresenta-se com a concentração de $100 \%$ ou seja, sem a diluição, portanto, em função dos resultados apresentados todos os solventes testados mostraram ser extremamente citotóxico, com $100 \%$ de morte celular.

No entanto, quando do seu uso clínico, o solvente é depositado, geralmente, com o canal radicular umedecido com o hipoclorito de sódio, por isso acredita-se que ocorra diluição, porém, numa proporção menor.

Diante das condições citadas anteriormente e pelos resultados obtidos pôde-se dizer que os solventes em concentrações menores são menos citotóxicos, todavia, a sua efetividade pode ser comprometida.

Após o tratamento e realizada a contagem celular foi possível observar que ainda havia células viáveis nas concentrações de 10 e 25\%. Diante disso, resolvemos aumentar o período de tratamento para verificar se existiria vida celular nos tempos de 10 e 15 minutos com o objetivo de obter uma curva tempo-resposta.

Nesta segunda etapa experimental a análise dos dados das Tabelas 5.5 e 5.8 nos revelou acentuada diminuição na média do número de células viáveis em todos os grupos experimentais. Comparando-se estatisticamente as diferenças entre as médias (Tabelas 5.6, 5.7, 5.9 e 5.10) notamos que o xilol apresentou diferença estatisticamente significante quando comparados aos demais grupos nas concentrações de 10 e 25\% para o tempo de 10 e 15 
minutos em contato com as células em cultura. $\mathrm{O}$ xilol apresentou ser $\mathrm{o}$ menos citotóxico nestas concentrações e tempos estudados.

$\mathrm{Na}$ tentativa de esclarecer questões quanto à interferência na viabilidade celular, levando-se em conta a forma de contato do material-teste com as células em cultura, realizamos a terceira etapa experimental. Para a realização desta, utilizamos lamínula de vidro, de tamanho padrão, com $25 \mu \mathrm{L}$ da solvente teste e vertemos sobre as células em cultura e em seguida $475 \mu \mathrm{L}$ de DMEM foi depositado (contato direto). No contato indireto, a mesma quantidade de DMEM foi depositado diretamente sobre as células de fibroblastos e sobre este $25 \mu \mathrm{L}$ de solvente foi depositado. A concentração final foi de $5 \%$ e o tempo de 5 minutos. Os resultados dessa terceira etapa experimental mostraram que houve diferença significativa quanto ao número de células viáveis, de acordo com a forma de contato. O óleo de laranja revelou diferença extremamente significante nas concentrações de $5 \%$ e 10\% na condição de contato indireto em comparação aos demais solventes, mostrando ser um solvente menos citotóxico. $\mathrm{O}$ xilol em contato indireto à 5 e $10 \%$ também apresentou diferença estatisticamente significante em relação a outros solventes, como podemos observar nas Tabelas 5.12 e 5.13

A falta na literatura de uma forma padronizada estrita do material para o teste de citotoxicidade e ausência de considerações a este respeito tornou a avaliação final do teste duvidosa causando risco ao seu resultado. Constatamos que os autores Spangberg (1969); Kettering \& Torabinejad (1988) compartilhavam da idéia defendida. 
A comparação dos resultados experimentais in vivo e in vitro pode ser realizada quando as condições de cultura e preparo dos materiais forem similares. A utilização de materiais que permitem homogeneização através de preparo artificial, não oferece resposta apropriada com relação à toxicidade geral, pois tais preparos deveriam auxiliar no estudo comparativo dos mesmos.

Durante o experimento observamos que a homogeneização em álcool produziu uma suspensão bastante fina de partículas de material quando este foi misturado com o meio de cultura. Essa homogeneização promoveu um contato constante com as células e qualquer componente tóxico que poderia ser removido esteve em contato com as células pelo tempo suficiente para respondê-lo. Diluição equivalente de álcool absoluto no mesmo meio de cultura foi testado para averiguar se existia qualquer efeito deletério sobre a sobrevivência celular e observou-se pequena redução na viabilidade celular. Permitindo assim, a realização de um estudo comparativo dos solventes em condições similares de contato sobre as células em cultura, minimizando deste modo, a interferência de densidade e volatilidade das substâncias estudadas, visto que, todas apresentaram características semelhantes de miscibilidade em álcool absoluto (The Condensed Chemical Dictionary, 1966; The Merck Index, 1989; Dorland's illustrated medical dictionary, 1994)

O problema geral em todas as situações de teste foi estimar à concentração teste relevante. Testes de solubilização inicial foram realizados com álcool absoluto na proporção de 10, 20 e 50\%, sendo este último aceitável com todos os solventes de guta-percha. O polietilenoglicol também 
foi testado como agente solubilizante, porém foi menos eficaz em tornar as substâncias estudadas miscíveis em meio de cultura. Nesta quarta etapa experimental, os solventes foram solubilizados previamente com o álcool absoluto para torná-los miscíveis em meio de cultura (DMEM) e a concentração final foi de $5 \%$.

Os resultados desta etapa experimental revelaram que todos os grupos se comportaram da maneira semelhante, com diferença estatisticamente significante apenas para o grupo controle, representado pelo álcool absoluto diluído em meio de cultura na mesma proporção utilizado para solubilizar os solventes. O óleo de laranja apresentou diferença significante em relação aos demais e foi o menos citotóxico, seguido por eucaliptol, como pudemos verificar pela Tabela 5.14 e Figura 5.19 .

Diferentes técnicas foram relatadas e aplicadas para quantificar a viabilidade e/ou proliferação celular após a exposição in vitro dos materiais. Exemplos: contagem de células vitais, através da exclusão do corante, Daniel (1998), Freshney (2000); medição com a liberação de isótopo radioativo, Spangberg (1973), Spangberg \& Al-Nazhan (1988); medição pela liberação de produtos celulares no meio de cultura, Meryon (1988), Tyas (1988); medição pela mudança na atividade celular e determinando a capacidade das células se dividirem (Helgeland \& Leirskar, 1972); crescimento celular em filtro Millipore, Wennberg (1988); medição da densidade celular através de analisador foto-padrão microcumputadorizado, Kawahara (1988). 
A maioria dos testes em cultura de células se fundamenta no colapso da integridade da membrana produzida pela ação de uma substância teste. No nosso experimento, o método de avaliação foi determinado pela inclusão de corante, azul Trypan, nas células normalmente impermeáveis. Este efeito é imediato e a contagem é simples e eficaz.

Células HeLa foram utilizadas em alguns trabalhos como de Spangberg, 1969; Kantz et al., 1974. Já Santos, 1998, utilizou células fibroblásticas originárias do tecido pulpar e células de fibroblastos NIH 3T3 e fez observação que os 2 tipos celulares não apresentaram diferença na resposta de citotoxicidade. Baseado neste trabalho, as células NIH 3T3 foram utilizadas nesta pesquisa como uma linhagem celular relativamente de fácil obtenção, manipulação, perpetuação e por não envolvem aspectos éticos em pesquisa de animais e seres humanos.

$\mathrm{Na}$ busca da padronização dos procedimentos comparamos, neste estudo, os solventes quanto à citotoxicidade em concentrações variadas e próximas da situação mais compatível ao uso clínico.

Os resultados indicaram que o preparo do material foi extremamente importante quando da utilização da metodologia in vitro e salientamos a importância da sistematização no processo de análise através da padronização da pesquisa.

Por fim, todos os solventes testados demonstraram ser capazes de comprometer a viabilidade celular, nestas condições de estudo, mesmo em pequenas concentrações, somado ao fato que na literatura ainda não existem novos solventes com eficácia e toxicidade comprovadas, todos os 
solventes estudados, neste trabalho, não devem atingir as proximidades do forame apical.

A escolha do solvente deve ser fundamentada pela eficácia e pela compatibilidade biológica, além de agregar os cuidados durante a aplicação destes dentro do canal radicular, como por exemplo: com o auxílio de seringa tipo Luer e cânula de calibre fino, e que o mesmo entre em contato com o material obturador a ser solubilizado. Vale ressaltar que a secagem do canal radicular antes da aplicação do solvente favorece a sua ação.

No presente trabalho o óleo de laranja mostrou ser o menos citotóxico, em todas as condições das etapas experimentais, razões pelas quais sugere o desenvolvimento de outros estudos em animais, com o propósito de estabelecer as reações teciduais in vivo, o que pode cooperar para a aplicação desse, com devida segurança na prática clínica. 


\section{CONCLUSÕES}

Com base no estudo realizado e discutido, frente às diferentes condições experimentais, os dados deste trabalho nos permitem concluir que:

1. Todos os solventes estudados são citotóxicos independente da forma de preparo e tipo de contato com as células.

2. A porcentagem de viabilidade celular diminui significativamente quando a concentração do solvente é aumentada.

3. O tempo de tratamento influencia na citotoxicidade dos solventes, quanto maior o tempo, maior efeito citotóxico.

4. O xilol é menos citotóxico quando é adicionado diretamente ao meio de cultura, sem preparo prévio.

5. O óleo de laranja é menos citotóxico quando os solventes são solubilizados previamente em álcool absoluto.

6. O clorofórmio e halotano são solventes extremamente citotóxicos mesmo em mínimas concentrações e menor tempo estudado.

7. O eucaliptol também mostra efeito citotóxico, em qualquer situação experimental. 
ANEXOS 


\section{ANEXO A - Etapa 1}

Tabela An.A1 - Valores originais do número de células viáveis (X10 ${ }^{4}$ no experimento com concentrações de 0, 5, 10, 25, 50 e 100\% do solvente óleo de laranja para o tempo de 5 minutos

\begin{tabular}{|c|c|c|c|c|c|c|}
\hline $\begin{array}{l}\text { concentração } \\
\text { células } \\
\text { iniciais }\end{array}$ & \multicolumn{5}{|c|}{$\begin{array}{l}\text { células } \\
\text { iniciais }\end{array}$} & 100 \\
\hline & 9.25 & 2.5 & 0.5 & 0.25 & 0 & 0 \\
\hline 1 & 9.25 & 2.75 & 0.75 & 0 & 0 & 0 \\
\hline \multirow[t]{3}{*}{9.75} & 9 & 4.25 & 2 & 0 & 0 & 0 \\
\hline & 7.75 & 2.5 & 0.25 & 0 & 0 & 0 \\
\hline & 10.5 & 1.5 & 0.25 & 0.5 & 0 & 0 \\
\hline II & 9.5 & 2.5 & 1.75 & 0 & 0 & 0 \\
\hline \multirow[t]{3}{*}{11.08} & 8.25 & 3.5 & 0.75 & 0 & 0 & 0 \\
\hline & 11.25 & 3.75 & 0.25 & 0 & 0 & 0 \\
\hline & 8.75 & 2.5 & 0.5 & 0 & 0 & 0 \\
\hline III & 9 & 2 & 0.75 & 0 & 0 & 0 \\
\hline \multirow[t]{2}{*}{14.50} & 13.5 & 1.25 & 1.25 & 0 & 0 & 0 \\
\hline & 13.25 & 3.25 & 1.75 & 0.25 & 0 & 0 \\
\hline Média 11.77 & 9.93 & 2.68 & 0.89 & 0.083 & 0 & 0 \\
\hline$(100 \%)$ & $(84 \%)$ & $(22 \%)$ & $(7 \%)$ & 0 & 0 & 0 \\
\hline
\end{tabular}


Tabela An.A2 - Valores originais do número de células viáveis $\left(X 10^{4}\right)$ no experimento com concentrações de 0, 5, 10, 25, 50 e 100\% do eucaliptol para o tempo de 5 minutos

\begin{tabular}{|c|c|c|c|c|c|c|}
\hline $\begin{array}{l}\text { concentração } \\
\text { células } \\
\text { iniciais }\end{array}$ & 0 & \multicolumn{4}{|c|}{$\begin{array}{l}\text { células } \\
\text { iniciais }\end{array}$} & 100 \\
\hline & 10.5 & 0 & 0 & 0 & 0 & 0 \\
\hline 1 & 9.5 & 0 & 0 & 0 & 0 & 0 \\
\hline \multirow[t]{3}{*}{12.16} & 9.5 & 0 & 0 & 0 & 0 & 0 \\
\hline & 10.5 & 0.25 & 0 & 0 & 0 & 0 \\
\hline & 10 & 0 & 0 & 0 & 0 & 0 \\
\hline II & 10.25 & 0 & 0 & 0 & 0 & 0 \\
\hline \multirow[t]{3}{*}{12} & 10.25 & 0 & 0 & 0 & 0 & 0 \\
\hline & 8.75 & 0 & 0 & 0 & 0 & 0 \\
\hline & 11.75 & 0.5 & 0 & 0 & 0 & 0 \\
\hline III & 12.5 & 0.75 & 0 & 0 & 0 & 0 \\
\hline \multirow[t]{2}{*}{13.5} & 12.75 & 0.25 & 0 & 0 & 0 & 0 \\
\hline & 9.25 & 0 & 0 & 0 & 0 & 0 \\
\hline Média 12.55 & 10.46 & 0.14 & 0 & 0 & 0 & 0 \\
\hline$\% \quad(100 \%)$ & $(83 \%)$ & $(1 \%)$ & 0 & 0 & 0 & 0 \\
\hline
\end{tabular}


Tabela An.A3 - Valores originais do número de células viáveis $\left(X 10^{4}\right)$ no experimento com concentrações de 0, 5, 10, 25, 50 e 100\% do solvente xilol para o tempo de 5 minutos

\begin{tabular}{|c|c|c|c|c|c|c|}
\hline $\begin{array}{l}\text { concentração } \\
\text { células } \\
\text { iniciais }\end{array}$ & 0 & 5 & 10 & 25 & 50 & 100 \\
\hline & 11.75 & 0.75 & 1.25 & 1 & 0 & 0 \\
\hline 1 & 11.25 & 1.5 & 1.25 & 1 & 0 & 0 \\
\hline \multirow[t]{3}{*}{13.83} & 8.25 & 2.75 & 1.25 & 1.25 & 0 & 0 \\
\hline & 10.75 & 3 & 1.25 & 1.25 & 0 & 0 \\
\hline & 9 & 3.5 & 1.5 & 0.5 & 0 & 0 \\
\hline II & 9.25 & 3.75 & 2 & 0.75 & 0 & 0 \\
\hline \multirow[t]{3}{*}{9.5} & 8 & 2.5 & 1.5 & 0.75 & 0 & 0 \\
\hline & 8.25 & 2.75 & 1.25 & 0.25 & 0 & 0 \\
\hline & 7.75 & 3 & 1 & 1 & 0 & 0 \\
\hline III & 9.5 & 2.75 & 1.75 & 1.25 & 0 & 0 \\
\hline \multirow[t]{2}{*}{13.33} & 11.25 & 3.5 & 2 & 1 & 0 & 0 \\
\hline & 10 & 3.75 & 2 & 1 & 0 & 0 \\
\hline Média 12.22 & 9.58 & 2.79 & 1.5 & 0.91 & 0 & 0 \\
\hline$\% \quad(100 \%)$ & $(78 \%)$ & $(22 \%)$ & $(12 \%)$ & $(7 \%)$ & 0 & 0 \\
\hline
\end{tabular}


Tabela An.A4 - Valores originais do número de células viáveis $\left(X 10^{4}\right)$ no experimento com concentrações de 0, 5, 10, 25, 50 e 100\% do solvente clorofórmio para o tempo de 5 minutos

\begin{tabular}{|c|c|c|c|c|c|c|}
\hline $\begin{array}{l}\text { concentração } \\
\text { células } \\
\text { iniciais }\end{array}$ & 0 & 5 & 10 & 25 & 50 & 100 \\
\hline & 9.75 & 0 & 0 & 0 & 0 & 0 \\
\hline 1 & 9.5 & 0.5 & 0 & 0 & 0 & 0 \\
\hline \multirow[t]{3}{*}{10.75} & 10.25 & 0 & 0 & 0 & 0 & 0 \\
\hline & 9 & 0 & 0 & 0 & 0 & 0 \\
\hline & 9.5 & 0 & 0 & 0 & 0 & 0 \\
\hline II & 9.25 & 0 & 0 & 0 & 0 & 0 \\
\hline \multirow[t]{2}{*}{11.5} & 10.75 & 0 & 0 & 0 & 0 & 0 \\
\hline & 11.25 & 0 & 0 & 0 & 0 & 0 \\
\hline & 11 & 0 & 0 & 0 & 0 & 0 \\
\hline III & 9 & 0.25 & 0 & 0 & 0 & 0 \\
\hline \multirow[t]{2}{*}{13.75} & 11.75 & 0.25 & 0 & 0 & 0 & 0 \\
\hline & 10.75 & 0.25 & 0 & 0 & 0 & 0 \\
\hline Média 12 & 10.14 & 0.10 & 0 & 0 & 0 & 0 \\
\hline$\%(100 \%)$ & $(84 \%)$ & $(0.83 \%)$ & 0 & 0 & 0 & 0 \\
\hline
\end{tabular}


Tabela An.A5 - Valores originais do número de células viáveis $\left(X 10^{4}\right)$ no experimento com concentrações de 0, 5, 10, 25, 50 e 100\% do solvente halotano para o tempo de 5 minutos

\begin{tabular}{|c|c|c|c|c|c|c|}
\hline $\begin{array}{l}\text { concentração } \\
\text { células } \\
\text { iniciais }\end{array}$ & 0 & 5 & 10 & 25 & 50 & 100 \\
\hline & 9 & 0 & 0 & 0 & 0 & 0 \\
\hline I & 8.25 & 0 & 0 & 0 & 0 & 0 \\
\hline \multirow[t]{3}{*}{14.91} & 8 & 0 & 0 & 0 & 0 & 0 \\
\hline & 10.5 & 0 & 0 & 0 & 0 & 0 \\
\hline & 9.25 & 0 & 0 & 0 & 0 & 0 \\
\hline II & 10.5 & 0 & 0 & 0 & 0 & 0 \\
\hline \multirow[t]{2}{*}{10.66} & 9 & 0 & 0 & 0 & 0 & 0 \\
\hline & 9.75 & 0 & 0 & 0 & 0 & 0 \\
\hline & 10.75 & 0 & 0 & 0 & 0 & 0 \\
\hline III & 10.5 & 0 & 0 & 0 & 0 & 0 \\
\hline \multirow[t]{2}{*}{11.33} & 9.75 & 0 & 0 & 0 & 0 & 0 \\
\hline & 9.5 & 0 & 0 & 0 & 0 & 0 \\
\hline Média 12.30 & 9.56 & 0 & 0 & 0 & 0 & 0 \\
\hline$\%(100 \%)$ & $(77 \%)$ & 0 & 0 & 0 & 0 & 0 \\
\hline
\end{tabular}




\section{ANEXO B - Etapa 2}

Tabela An.B1 - Valores originais do número de células viáveis $\left(X 10^{4}\right)$ no experimento com concentrações de 0,10 e $25 \%$ do solvente óleo de casca de laranja para o tempo de 10 minutos

\begin{tabular}{|c|c|c|c|}
\hline $\begin{array}{l}\text { concentração } \\
\text { células } \\
\text { iniciais }\end{array}$ & 0 & 10 & 25 \\
\hline & 8 & 0.5 & 0 \\
\hline 1 & 12 & 0.5 & 0 \\
\hline \multirow[t]{2}{*}{13.16} & 8 & 0.5 & 0 \\
\hline & 10.5 & 0 & 0.25 \\
\hline & 10 & 0 & 0 \\
\hline II & 9.5 & 0 & 0 \\
\hline \multirow[t]{2}{*}{12.75} & 10.5 & 0 & 0 \\
\hline & 9.5 & 0.25 & 0 \\
\hline & 8 & 0 & 0 \\
\hline III & 11 & 1.5 & 0 \\
\hline \multirow[t]{2}{*}{10} & 8.5 & 1.75 & 0.25 \\
\hline & 12.5 & 1 & 0.25 \\
\hline Média 11.97 & 9.83 & 0.5 & 0.06 \\
\hline$\% \quad(100 \%)$ & $(82 \%)$ & $(5 \%)$ & $(0.50 \%)$ \\
\hline
\end{tabular}


Tabela An.B2 - Valores originais do número de células viáveis $\left(X 10^{4}\right)$ no experimento com concentrações de 0,10 e $25 \%$ do solvente eucaliptol para o tempo de 10 minutos

\begin{tabular}{|c|c|c|c|}
\hline $\begin{array}{l}\text { concentração } \\
\text { células } \\
\text { iniciais }\end{array}$ & 0 & 10 & 25 \\
\hline $\begin{array}{c}\text { I } \\
12.16\end{array}$ & $\begin{array}{c}9 \\
9.75 \\
8.75 \\
11.75\end{array}$ & $\begin{array}{c}0.25 \\
0 \\
0 \\
0\end{array}$ & $\begin{array}{l}0 \\
0 \\
0 \\
0\end{array}$ \\
\hline $\begin{array}{c}\text { II } \\
11.5\end{array}$ & $\begin{array}{c}9 \\
8.75 \\
9.75 \\
10.25\end{array}$ & $\begin{array}{l}0 \\
0 \\
0 \\
0\end{array}$ & $\begin{array}{l}0 \\
0 \\
0 \\
0\end{array}$ \\
\hline $\begin{array}{l}\text { III } \\
11\end{array}$ & $\begin{array}{c}8.5 \\
8.75 \\
9 \\
9.5\end{array}$ & $\begin{array}{l}0 \\
0 \\
0 \\
0\end{array}$ & $\begin{array}{l}0 \\
0 \\
0 \\
0\end{array}$ \\
\hline $\begin{array}{c}\text { Média } 11.55 \\
\% \quad(100 \%)\end{array}$ & $\begin{array}{c}9.39 \\
(81.3 \%)\end{array}$ & $\begin{array}{c}0.02 \\
(0.17 \%)\end{array}$ & $\begin{array}{l}0 \\
0\end{array}$ \\
\hline
\end{tabular}


Tabela An.B3 - Valores originais do número de células viáveis $\left(X 10^{4}\right)$ no experimento com concentrações de 0,10 e $25 \%$ do solvente xilol para o tempo de 10 minutos

\begin{tabular}{c|c|c|c}
\hline concentração & & & \\
células & & & 25 \\
iniciais & 0 & 10 & \\
& & & 0.8 \\
I & 9.2 & 1.8 & 0.6 \\
12.83 & 10 & 2 & 0.6 \\
& 9.8 & 3.2 & 0.4 \\
\hline \multirow{2}{*}{ II } & 14.8 & 2.6 & 0.4 \\
& 11 & 0.8 & 0.6 \\
\hline \multirow{2}{*}{ III } & 9.6 & 0.8 & 0.4 \\
11 & 9.6 & 0.6 & 0.4 \\
\hline Média 11.55 & 10 & 0.6 & 0.4 \\
(100\%) & 9.2 & 1 & 0.4 \\
\hline
\end{tabular}


Tabela An.B4 - Valores originais do número de células viáveis $\left(X 10^{4}\right)$ no experimento com concentrações de 0,10 e $25 \%$ do solvente clorofórmio para o tempo de 10 minutos

\begin{tabular}{|c|c|c|c|}
\hline $\begin{array}{l}\text { concentração } \\
\text { células } \\
\text { iniciais }\end{array}$ & 0 & 10 & 25 \\
\hline \multirow{3}{*}{ I } & 9.5 & 0 & 0 \\
\hline & 7.25 & 0 & 0 \\
\hline & 10 & 0 & 0 \\
\hline \multirow[t]{2}{*}{11.66} & 13.25 & 0 & 0 \\
\hline & 8.25 & 0 & 0 \\
\hline$\|$ & 9.75 & 0 & 0 \\
\hline \multirow[t]{2}{*}{11.33} & 11.5 & 0 & 0 \\
\hline & 12 & 0 & 0 \\
\hline & 9.75 & 0 & 0 \\
\hline III & 10.5 & 0 & 0 \\
\hline \multirow[t]{2}{*}{12} & 11.25 & 0 & 0 \\
\hline & 12 & 0 & 0 \\
\hline Media 11.64 & 10.41 & 0 & 0 \\
\hline$\% \quad(100 \%)$ & (89\%) & 0 & 0 \\
\hline
\end{tabular}


Tabela An.B5 - Valores originais do número de células viáveis $\left(X 10^{4}\right)$ no experimento com concentrações de 0,10 e $25 \%$ do solvente halotano para o tempo de 10 minutos

\begin{tabular}{c|c|c|c}
\hline concentração & $\mathbf{0}$ & $\mathbf{1 0}$ & $\mathbf{2 5}$ \\
células & & & \\
iniciais & & & \\
\hline & & & 0 \\
I & 8.6 & 0 & 0 \\
11.5 & 9.2 & 0 & 0 \\
& 10 & 0 & 0 \\
\hline II & 11.2 & 0 & 0 \\
10.75 & 10.2 & 0 & 0 \\
& 10.8 & 0 & 0 \\
\hline III & 9.2 & 0 & 0 \\
11.75 & 10.8 & 0 & 0 \\
& 10.2 & 0 & 0 \\
\hline Média 11.33 & 10.2 & 0 & 0 \\
\hline
\end{tabular}


Tabela An.B6 - Valores originais do número de células viáveis $\left(X 10^{4}\right)$ no experimento com concentrações de 0,10 e $25 \%$ do solvente óleo de casca de laranja para o tempo de 15 minutos

\begin{tabular}{|c|c|c|c|}
\hline $\begin{array}{l}\text { concentração } \\
\text { células } \\
\text { iniciais }\end{array}$ & 0 & 10 & 25 \\
\hline & 13 & 0 & 0 \\
\hline I & 9.5 & 0.5 & 0 \\
\hline \multirow[t]{2}{*}{13.16} & 7 & 0 & 0 \\
\hline & 8.5 & 0 & 0.25 \\
\hline & 12 & 0 & 0 \\
\hline II & 11 & 0 & 0 \\
\hline \multirow[t]{2}{*}{12.75} & 12.5 & 0 & 0 \\
\hline & 11.5 & 0 & 0 \\
\hline & 8.5 & 0 & 0 \\
\hline III & 10.5 & 0 & 0 \\
\hline \multirow[t]{2}{*}{10} & 11 & 0.5 & 0 \\
\hline & 12 & 0 & 0.75 \\
\hline Média 11.97 & 10.58 & 0.08 & 0.08 \\
\hline$\% \quad(100 \%)$ & (88\%) & $(0.6 \%)$ & $(0.6 \%)$ \\
\hline
\end{tabular}


Tabela An.B7 - Valores originais do número de células viáveis $\left(X 10^{4}\right)$ no experimento com concentrações de 0,10 e $25 \%$ do solvente eucaliptol para o tempo de 15 minutos

\begin{tabular}{|c|c|c|c|}
\hline $\begin{array}{l}\text { concentração } \\
\text { células } \\
\text { iniciais }\end{array}$ & 0 & 10 & 25 \\
\hline $\begin{array}{c}\text { I } \\
12.16\end{array}$ & $\begin{array}{c}9 \\
10 \\
9 \\
8.75\end{array}$ & $\begin{array}{l}0 \\
0 \\
0 \\
0\end{array}$ & $\begin{array}{l}0 \\
0 \\
0 \\
0\end{array}$ \\
\hline $\begin{array}{c}\text { II } \\
11.5\end{array}$ & $\begin{array}{c}10 \\
9 \\
9.5 \\
9.25\end{array}$ & $\begin{array}{l}0 \\
0 \\
0 \\
0\end{array}$ & $\begin{array}{l}0 \\
0 \\
0 \\
0\end{array}$ \\
\hline $\begin{array}{l}\text { III } \\
11\end{array}$ & $\begin{array}{c}9.25 \\
9.75 \\
9 \\
11\end{array}$ & $\begin{array}{l}0 \\
0 \\
0 \\
0\end{array}$ & $\begin{array}{l}0 \\
0 \\
0 \\
0\end{array}$ \\
\hline $\begin{array}{c}\text { Média } 11.55 \\
\% \quad(100 \%)\end{array}$ & $\begin{array}{c}9.45 \\
(81.81 \%)\end{array}$ & $\begin{array}{l}0 \\
0\end{array}$ & $\begin{array}{l}0 \\
0\end{array}$ \\
\hline
\end{tabular}


Tabela An.B8 - Valores originais do número de células viáveis $\left(X 10^{4}\right)$ no experimento com concentrações de 0,10 e $25 \%$ do solvente xilol para o tempo de 15 minutos

\begin{tabular}{|c|c|c|c|}
\hline $\begin{array}{l}\text { concentração } \\
\text { células } \\
\text { iniciais }\end{array}$ & 0 & 10 & 25 \\
\hline $\begin{array}{c}\text { I } \\
12.83\end{array}$ & $\begin{array}{l}10.2 \\
11.4 \\
9.6 \\
9.6\end{array}$ & $\begin{array}{l}0.4 \\
0.4 \\
0.4 \\
0.2\end{array}$ & $\begin{array}{c}0.2 \\
0.2 \\
0 \\
0.2\end{array}$ \\
\hline $\begin{array}{c}\text { II } \\
10.83\end{array}$ & $\begin{array}{c}10.8 \\
11.6 \\
9.4 \\
10.4\end{array}$ & $\begin{array}{l}0.4 \\
0.6 \\
0.8 \\
0.2\end{array}$ & $\begin{array}{l}0.2 \\
0.2 \\
0.4 \\
0.4\end{array}$ \\
\hline $\begin{array}{l}\text { III } \\
11\end{array}$ & $\begin{array}{c}10.2 \\
10.6 \\
9.6 \\
8.8\end{array}$ & $\begin{array}{l}0.6 \\
0.6 \\
0.6 \\
0.6\end{array}$ & $\begin{array}{l}0.2 \\
0.2 \\
0.2 \\
0.2\end{array}$ \\
\hline $\begin{array}{c}\text { Média } 11.55 \\
\%(100 \%)\end{array}$ & $\begin{array}{l}10.18 \\
(88 \%)\end{array}$ & $\begin{array}{c}0.48 \\
(4.1 \%)\end{array}$ & $\begin{array}{c}0.21 \\
(1.8 \%)\end{array}$ \\
\hline
\end{tabular}


Tabela An.B9 - Valores originais do número de células viáveis $\left(X 10^{4}\right)$ no experimento com concentrações de 0,10 e $25 \%$ do solvente clorofórmio para o tempo de 15 minutos

\begin{tabular}{|c|c|c|c|}
\hline $\begin{array}{l}\text { concentração } \\
\text { células } \\
\text { iniciais }\end{array}$ & 0 & 10 & 25 \\
\hline & 8.75 & 0 & 0 \\
\hline I & 8.75 & 0 & 0 \\
\hline \multirow[t]{2}{*}{11.66} & 9.25 & 0 & 0 \\
\hline & 9.75 & 0 & 0 \\
\hline & 9.75 & 0 & 0 \\
\hline II & 11 & 0 & 0 \\
\hline \multirow[t]{2}{*}{11.33} & 12 & 0 & 0 \\
\hline & 10.75 & 0 & 0 \\
\hline & 10 & 0 & 0 \\
\hline III & 10.75 & 0 & 0 \\
\hline \multirow[t]{2}{*}{12} & 11.5 & 0 & 0 \\
\hline & 11.75 & 0 & 0 \\
\hline Média 11.64 & 10.33 & 0 & 0 \\
\hline$\% \quad(100 \%)$ & $(88.7 \%)$ & 0 & 0 \\
\hline
\end{tabular}


Tabela An.B10 - Valores originais do número de células viáveis $\left(X 10^{4}\right)$ no experimento com concentrações de 0,10 e $25 \%$ do solvente halotano para o tempo de 15 minutos

\begin{tabular}{|c|c|c|c|}
\hline $\begin{array}{l}\text { concentração } \\
\text { células } \\
\text { iniciais }\end{array}$ & 0 & 10 & 25 \\
\hline & 9.2 & 0 & 0 \\
\hline 1 & 9.8 & 0 & 0 \\
\hline \multirow[t]{2}{*}{11.5} & 9 & 0 & 0 \\
\hline & 10.6 & 0 & 0 \\
\hline & 10 & 0 & 0 \\
\hline II & 11.4 & 0 & 0 \\
\hline \multirow[t]{2}{*}{10.75} & 10.6 & 0 & 0 \\
\hline & 10 & 0 & 0 \\
\hline & 9.8 & 0 & 0 \\
\hline III & 10.6 & 0 & 0 \\
\hline \multirow[t]{2}{*}{11.75} & 11 & 0 & 0 \\
\hline & 10.2 & 0 & 0 \\
\hline Média 11.33 & 10.18 & 0 & 0 \\
\hline$\% \quad(100 \%)$ & $(89.8 \%)$ & 0 & 0 \\
\hline
\end{tabular}




\section{ANEXO C - Etapa 3}

Tabela An.C1 - Valores originais do número de células viáveis $\left(X 10^{4}\right)$ no experimento com concentrações de 0, 5 e $10 \%$ do solvente óleo de casca de laranja para o tempo de 5 minutos. Solvente em contato direto com as células de fibroblastos com auxílio de lamínula de vidro e solvente vertido sobre o DMEM

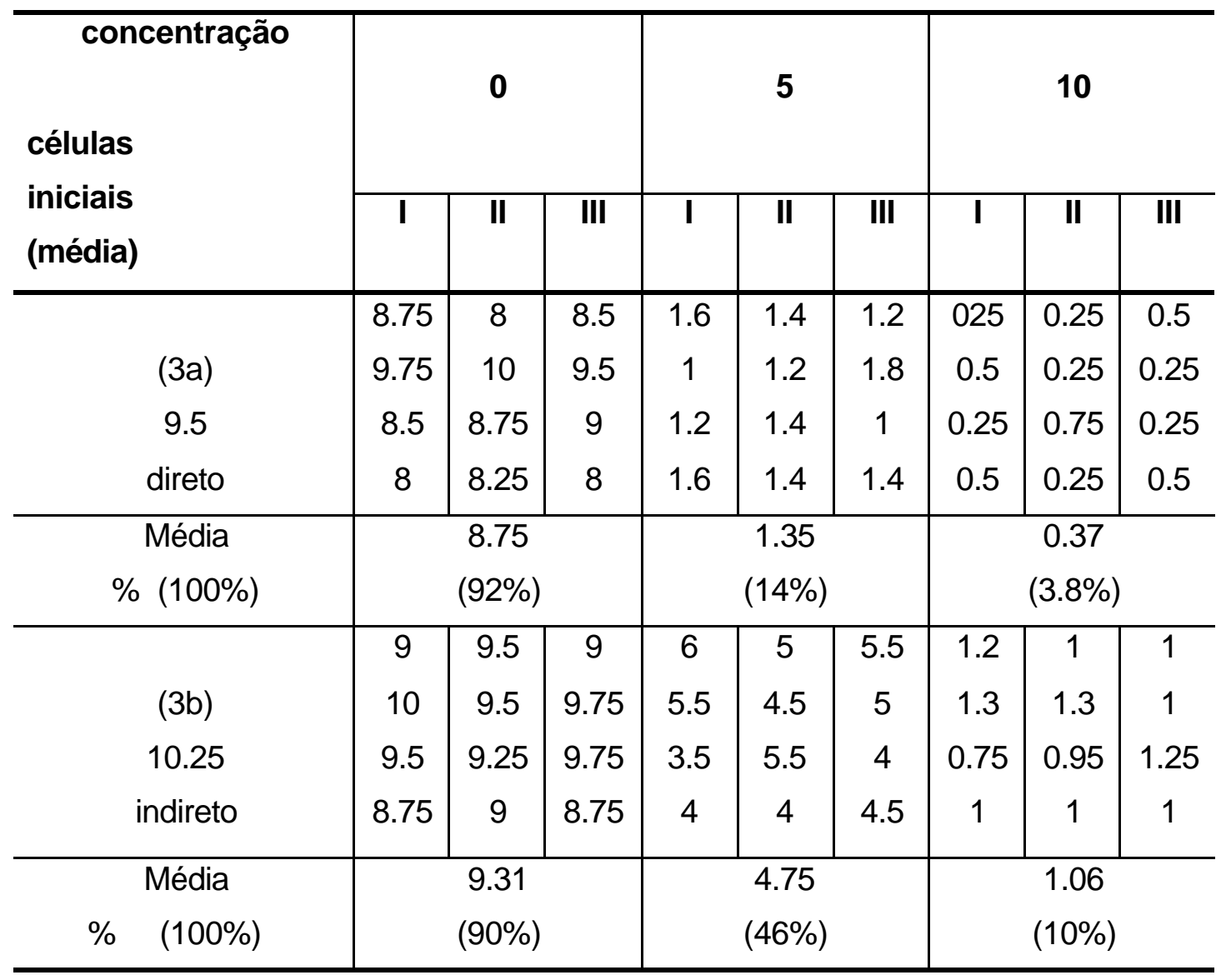


Tabela An.C2 - Valores originais do número de células viáveis $\left(\mathrm{X} 10^{4}\right)$ no experimento com concentrações de 0, 5 e $10 \%$ do solvente eucaliptol para o tempo de 5 minutos. Solvente em contato direto com as células de fibroblastos com auxílio de lamínula de vidro e solvente vertido sobre o DMEM

\begin{tabular}{|c|c|c|c|c|c|c|c|c|c|}
\hline \multirow{2}{*}{$\begin{array}{l}\text { células } \\
\text { iniciais } \\
\text { (média) }\end{array}$} & \multicolumn{3}{|c|}{0} & \multicolumn{3}{|c|}{5} & \multicolumn{3}{|c|}{10} \\
\hline & I & II & II & I & II & III & I & II & III \\
\hline & 8 & 8 & 8.5 & 0 & 0.25 & 0 & 0 & 0 & 0 \\
\hline (3a) & 9.75 & 10 & 9.5 & 0 & 0 & 0 & 0 & 0 & 0 \\
\hline 9.5 & 8.5 & 8.75 & 9 & 0.5 & 0.25 & 0 & 0 & 0 & 0 \\
\hline direto & 8 & 8.25 & 8 & 0 & 0 & 0.5 & 0 & 0 & 0 \\
\hline $\begin{array}{c}\text { Média } \\
\%(100 \%)\end{array}$ & \multicolumn{3}{|c|}{$\begin{array}{c}8.75 \\
(92.1 \%)\end{array}$} & \multicolumn{3}{|c|}{$\begin{array}{l}0.12 \\
(1 \%)\end{array}$} & \multicolumn{3}{|c|}{$\begin{array}{l}0 \\
0\end{array}$} \\
\hline & 9 & 9.5 & 9 & 1.25 & 0.75 & 0.75 & 0 & 0 & 0 \\
\hline (3b) & 10 & 9.5 & 9.75 & 0 & 0.25 & 0.75 & 0 & 0 & 0 \\
\hline 10.25 & 9.5 & 9.25 & 9.75 & 0.5 & 0.5 & 0 & 0 & 0 & 0 \\
\hline indireto & 8.75 & 9 & 8.75 & 0 & 0.25 & 0 & 0 & 0 & 0 \\
\hline Média & \multirow{2}{*}{\multicolumn{3}{|c|}{$\begin{array}{c}9.31 \\
(90 \%)\end{array}$}} & \multirow{2}{*}{\multicolumn{3}{|c|}{$\begin{array}{l}0.43 \\
(4 \%)\end{array}$}} & \multirow{2}{*}{\multicolumn{3}{|c|}{0}} \\
\hline$\% \quad(100 \%)$ & & & & & & & & & \\
\hline
\end{tabular}


Tabela An.C3 - Valores originais do número de células viáveis $\left(X 10^{4}\right)$ no experimento com concentrações de 0, 5 e $10 \%$ do solvente xilol para o tempo de 5 minutos. Solvente em contato direto com as células de fibroblastos com auxílio de lamínula de vidro e solvente vertido sobre o DMEM

\begin{tabular}{|c|c|c|c|c|c|c|c|c|c|}
\hline \multirow{2}{*}{$\begin{array}{l}\text { concentração } \\
\text { células } \\
\text { iniciais } \\
\text { (média) }\end{array}$} & \multicolumn{3}{|c|}{0} & \multicolumn{3}{|c|}{5} & \multicolumn{3}{|c|}{10} \\
\hline & I & II & II & I & II & III & I & II & III \\
\hline & 8 & 8 & 8.5 & 0 & 0 & 0 & 0 & 0 & 0 \\
\hline (3a) & 9.75 & 10 & 9.5 & 0 & 0 & 0 & 0 & 0 & 0 \\
\hline 9.5 & 8.5 & 8.75 & 9 & 0 & 0 & 0 & 0 & 0 & 0 \\
\hline direto & 8 & 8.25 & 8 & 0 & 0 & 0 & 0 & 0 & 0 \\
\hline \multirow{2}{*}{$\begin{array}{ll} & \text { Média } \\
\% & (100 \%)\end{array}$} & \multirow{2}{*}{\multicolumn{3}{|c|}{$\begin{array}{l}8.75 \\
(92 \%)\end{array}$}} & \multirow{2}{*}{\multicolumn{3}{|c|}{$\begin{array}{l}0 \\
0\end{array}$}} & \multirow{2}{*}{\multicolumn{3}{|c|}{$\begin{array}{l}0 \\
0\end{array}$}} \\
\hline & & & & & & & & & \\
\hline & 9 & 9.5 & 9 & \multicolumn{3}{|c|}{4.5} & 1.8 & 1.5 & 1.6 \\
\hline$(3 b)$ & 10 & 9.5 & 9.75 & 5.25 & 4.5 & 4.25 & 1.9 & 1.75 & 1.9 \\
\hline 10.25 & 9.5 & 9.25 & 9.75 & 3 & 3.25 & 3.75 & 1.75 & 1.75 & 1.75 \\
\hline indireto & 8.75 & 9 & 8.75 & 3 & 3 & 3.25 & 1.25 & 1.95 & 1.45 \\
\hline \begin{tabular}{c}
\multicolumn{2}{c}{ Média } \\
$\% \quad(100 \%)$
\end{tabular} & \multicolumn{3}{|c|}{$\begin{array}{l}9.31 \\
(90 \%)\end{array}$} & \multicolumn{3}{|c|}{$\begin{array}{l}3.81 \\
(37 \%)\end{array}$} & \multicolumn{3}{|c|}{$\begin{array}{c}1.67 \\
(16 \%)\end{array}$} \\
\hline
\end{tabular}


Tabela An.C4 - Valores originais do número de células viáveis $\left(X 10^{4}\right)$ no experimento com concentrações de 0, 5 e $10 \%$ do solvente clorofórmio para o tempo de 5 minutos. Solvente em contato direto com as células de fibroblastos com auxílio de lamínula de vidro e solvente vertido sobre o DMEM

\begin{tabular}{|c|c|c|c|c|c|c|c|c|c|}
\hline \multirow{2}{*}{$\begin{array}{l}\text { concentração } \\
\text { células } \\
\text { iniciais } \\
\text { (média) }\end{array}$} & \multicolumn{3}{|c|}{0} & \multicolumn{3}{|c|}{5} & \multicolumn{3}{|c|}{10} \\
\hline & I & II & II & I & II & III & I & II & III \\
\hline & 8 & 8 & 8.5 & 0 & 0 & 0 & 0 & 0 & 0 \\
\hline (3a) & 9.75 & 10 & 9.5 & 0 & 0 & 0 & 0 & 0 & 0 \\
\hline 9.5 & 8.5 & 8.75 & 9 & 0 & 0 & 0 & 0 & 0 & 0 \\
\hline direto & 8 & 8.25 & 8 & 0 & 0 & 0 & 0 & 0 & 0 \\
\hline $\begin{array}{c}\text { Média } \\
\% \quad(100 \%)\end{array}$ & \multicolumn{3}{|c|}{$\begin{array}{c}8.75 \\
(92 \%)\end{array}$} & \multicolumn{3}{|c|}{$\begin{array}{l}0 \\
0\end{array}$} & \multicolumn{3}{|c|}{$\begin{array}{l}0 \\
0\end{array}$} \\
\hline & 9 & 9.5 & 9 & 0.25 & 0 & 0 & 0 & 0 & 0 \\
\hline (3b) & 10 & 9.5 & 9.75 & 0 & 0 & 0 & 0 & 0 & 0 \\
\hline 10.25 & 9.5 & 9.25 & 9.75 & 0 & 0.5 & 0 & 0 & 0 & 0 \\
\hline indireto & 8.75 & 9 & 8.75 & 0 & 0 & 0 & 0 & 0 & 0 \\
\hline $\begin{array}{c}\text { Média } \\
\% \quad(100 \%)\end{array}$ & \multicolumn{3}{|c|}{$\begin{array}{c}9.31 \\
(90 \%)\end{array}$} & \multicolumn{3}{|c|}{$\begin{array}{c}0.06 \\
(0.58 \%)\end{array}$} & \multicolumn{3}{|c|}{$\begin{array}{l}0 \\
0\end{array}$} \\
\hline
\end{tabular}


Tabela An.C5 - Valores originais do número de células viáveis $\left(X 10^{4}\right)$ no experimento com concentrações de 0, 5 e $10 \%$ do solvente halotano para o tempo de 5 minutos. Solvente em contato direto com as células de fibroblastos com auxílio de lamínula de vidro e solvente vertido sobre o DMEM

\begin{tabular}{|c|c|c|c|c|c|c|c|c|c|}
\hline \multirow{2}{*}{$\begin{array}{l}\text { concentração } \\
\text { células } \\
\text { iniciais } \\
\text { (média) }\end{array}$} & \multicolumn{3}{|c|}{0} & \multicolumn{3}{|c|}{5} & \multicolumn{3}{|c|}{10} \\
\hline & I & II & II & I & II & III & I & II & III \\
\hline & 8 & 8 & 8.5 & 0 & 0 & 0 & 0 & 0 & 0 \\
\hline (3a) & 9.75 & 10 & 9.5 & 0 & 0 & 0 & 0 & 0 & 0 \\
\hline 9.5 & 8.5 & 8.75 & 9 & 0 & 0 & 0 & 0 & 0 & 0 \\
\hline direto & 8 & 8.25 & 8 & 0 & 0 & 0 & 0 & 0 & 0 \\
\hline $\begin{array}{c}\text { Média } \\
\% \quad(100 \%)\end{array}$ & \multicolumn{3}{|c|}{$\begin{array}{l}8.75 \\
(92 \%)\end{array}$} & \multicolumn{3}{|c|}{$\begin{array}{l}0 \\
0\end{array}$} & \multicolumn{3}{|c|}{$\begin{array}{l}0 \\
0\end{array}$} \\
\hline & 9 & 9.5 & 9 & 0.25 & 0.5 & 0.5 & 0 & 0 & 0 \\
\hline (3b) & 10 & 9.5 & 9.75 & 2 & 1.75 & 1.0 & 0 & 0 & 0 \\
\hline 10.25 & 9.5 & 9.25 & 9.75 & 0.75 & 0.75 & 0.75 & 0 & 0 & 0 \\
\hline indireto & 8.75 & 9 & 8.75 & 0 & 0 & 0.75 & 0 & 0 & 0 \\
\hline $\begin{array}{c}\text { Média } \\
\%(100 \%)\end{array}$ & \multicolumn{3}{|c|}{$\begin{array}{c}9.31 \\
(90 \%)\end{array}$} & \multicolumn{3}{|c|}{$\begin{array}{l}0.75 \\
(7 \%)\end{array}$} & \multicolumn{3}{|c|}{$\begin{array}{l}0 \\
0\end{array}$} \\
\hline
\end{tabular}




\section{ANEXO D - Etapa 4}

Tabela An.D - Valores originais do número de células viáveis $\left(X 10^{4}\right)$ no experimento com concentração de $5 \%$ dos solventes estudados para o tempo de 5 minutos. Solventes foram solubilizados previamente em álcool absoluto

\begin{tabular}{|c|c|c|c|c|c|c|}
\hline $\begin{array}{l}\text { solventes } \\
\text { células } \\
\text { iniciais }\end{array}$ & $\begin{array}{c}\text { Controle } \\
\text { (álcool } \\
\text { absoluto) }\end{array}$ & $\begin{array}{c}\text { óleo } \\
\text { de } \\
\text { laranja }\end{array}$ & eucaliptol & xilol & clorofórmio & halotano \\
\hline & 7.2 & 1.4 & 0.2 & 0 & 0 & 0 \\
\hline 1 & 7.2 & 1.4 & 0.2 & 0 & 0 & 0 \\
\hline \multirow[t]{4}{*}{8.91} & 5.3 & 1.4 & 0 & 0 & 0 & 0 \\
\hline & 5.7 & 1.6 & 0.4 & 0 & 0 & 0 \\
\hline & 7.2 & 1.5 & 0.2 & 0 & 0 & 0 \\
\hline & 8.7 & 1.4 & 0 & 0 & 0 & 0 \\
\hline II & 8.7 & 1.4 & 0.2 & 0 & 0 & 0 \\
\hline \multirow[t]{2}{*}{9} & 7.2 & 1.4 & 0.2 & 0 & 0 & 0 \\
\hline & 5.5 & 1.4 & 0 & 0 & 0 & 0 \\
\hline II & 6.8 & 1.4 & 0.2 & 0 & 0 & 0 \\
\hline \multirow[t]{2}{*}{8.25} & 5.9 & 1.4 & 0.2 & 0 & 0 & 0 \\
\hline & 6.2 & 1.4 & 0 & 0 & 0 & 0 \\
\hline Média 8.72 & 6.8 & 0.43 & 0.016 & 0 & 0 & 0 \\
\hline$\%(100 \%)$ & $(77 \%)$ & $(16.3 \%)$ & $(0.37 \%)$ & 0 & 0 & 0 \\
\hline
\end{tabular}




\section{REFERÊNCIAS *}

AUN, C. E.; Santos, M. Quantity of apical extruded material and efficiency of five different methods of removing gutta-percha and sealer from root canalsin vitro evaluation. Rev Fac Odont FZL, São Paulo, v. 1, n. 2, p. 63-73, juldez. 1989.

BARBAKOW, F. H.; CLEATON-JONES, P.; FRIEDMAN, D. An evaluation of 566 cases of root canal therapy in general dental practice 2. Postoperative observations. J Endod, Chicago, v. 6, n. 3, p. 485-489, Mar. 1980.

BARBOSA, S. V; BURKED, D. H.; SPANBERG, L. S. W. Cytotoxic effects of gutta-percha solvents. J Endod, Chicago, v. 20, n. 1, p. 6-8, Jan. 1994.

BERGER, C.R. Endodontia. São Paulo: Pancast, 1998. 723 p.

* De acordo com ABNT NBR-6023: 2000. Abreviatura de periódicos segundo Bases de Dados MEDLINE. 
BETTI, L. V.; BRAMANTE, C. M. Quantec SC rotary instruments versus hand files for gutta-percha removal in root canal retreatment. Int Endod J, London, v. 34, n. 7, p. 514-519, Oct. 2001.

BROWNE, R. M. The in vitro assessment of the cytotoxicity of dental materials- does it have a role? Int Endod J, London, v. 21, n. 2, p. 50-58, Mar. 1988.

BROWNE, R. M.; TYAS, M. J. Biological testing of dental restorative materials in vitro- a review. J Oral Rehabil, Oxford, v. 6, n.4, p. 365-374, Oct. 1979.

CHANG, Y. C.; CHOU, M. Y. Cytotoxicity of halothane on the human gingival fibroblast cultures in vitro. J Endod, Chicago, v. 27, n. 2, p. 82-84, Feb. 2001.

COSTA, W. F.; ANTONIAZZI. J. H. Retratamento dos canais radiculares. In Atualização na clínica odontológica. São Paulo: Artes Médicas, 1992. $499 \mathrm{p}$.

DANIEL, R. L. D. P. Análise comparativa da citotoxicidade in vitro do iodofórmio e hidróxido de cálcio empregando-se dois veículos diferentes. 1998. 200f. Dissertação (Mestrado em Endodontia) - Faculdade de Odontologia da Universidade de São Paulo, São Paulo. 
DELLA NINA, L.; ETHER, S.; OLIVEIRA, E.; PAULO, S. Avaliação das propriedades de solventes de guta-percha. Quintessencia, Rio de Janeiro, v. 7, n. 9, p. 27-32, set. 1980 .

DORHAND' S ILLUSTRATED MEDICAL DICTIONARY. Philadelphia: W. B. Sanders Co., $28^{\text {th }}$ ed., 1994. 1940 p.

FEDERATION DENTAIRE INTERNATIONAL. Recommended standard practices for biological evaluation of dental materials. Int Dent J, London, v. 30, n. 2, p. 140-188, June 1980.

FERREIRA, J. J.; RHODES, J. S.; PITT FORD, T. R. The efficacy of guttapercha removal using Profiles. Int Endod J, London, v. 34, n. 4, p. 267-274, June 2001.

FRESHNEY, R. I. Culture of animal cells : a manual of basic techniques. $4^{\text {th }}$ ed. New York: Wiley-Liss, 2000. 577 p.

FRIEDMAN, S.; STABHOLTZ, A. Endodontic retreatment-case selection and technique. Part 1: criteria for case selection. J Endod, Chicago, v. 12, n. 1, p. 28-33, Jan. 1986. 
FRIEDMAN, S.; STABHOLTZ, A.; TAMSE, A. Endodontic retreatment-case selection and technique. Part 3: retreatment techniques. J Endod, Chicago, v. 16, n. 11, p. 543-549, Nov. 1990.

GILBERT, B. O.; RICE, R. T. Re-treatment in endodontics. Oral Surg Oral Med Oral Pathol, St. Louis, v. 64, n. 3, p. 333-338, Jan. 1987.

GÖRDUYSUS, M. Ö.; TASMAN, F.; TUNCER, S.; ETIKAN, I. Solubilizing efficiency of different gutta-percha solvents: a comparative study. J Nihon Univ Sch Dent, Tokyo, v. 39, n. 3, p. 133-135, Sept. 1997.

GUTMANN, J. L.; DUMSHA, T. C.; LOVDAHL, P. E.; HOVLAND, E. J. Problem solving in Endodontics - prevention, identification, and management. St. Louis: Mosby, 1997. 365 p.

HANSEN, M. G. Relative efficiency of solvents used in endodontics. J Endod, Chicago, v. 24, n. 1, p. 38-40, Jan. 1998.

HEALING, B.; TAMSHE, A. Evaluation of the success of endodontically treated teeth. Oral Surg Oral Med Oral Pathol, St. Louis, v. 30, n. 4, p. 533536, Oct. 1970. 
HELGELAND, K.; LEIRSKAR, J. A further testing of the effect of dental materials on growth and adhesion of animal cells in vitro. Scand J Dent Res, Oslo, v. 80, n. 3, p. 206-212, May/June 1972.

HENSTEN-PETTERSEN, A. Comparison of the methods available for assessing cytotoxicity. Int Endod J, London, v. 21, n. 2, p. 89-99, Mar. 1988.

HUNTER, K. R.; DOBLECKI, W.; PELLEU, G. B. Halothane and eucalyptol as alternatives to chloroform for softening gutta-percha. J Endod, Chicago, v. 17, n. 7 , p. 310-312, July 1991.

HÜSMANN, M.; STOTZ, S. Efficacy, cleaning ability and safety of different devices for gutta-percha removal in root canal retreatment. Int End J, London, v. 30, n. 4, p. 227-233, July 1997.

IMURA, N.; ZUOLO, M. L.; FERREIRA, M. O. F.; NOVO, N. F. Effectiveness of the canal finder and hand instrumentation in removal of guta-percha root fillings during root canal retreatment. Int Endod J, London, v. 29, n. 6, p. 382-386, Nov. 1996.

INGLE, J. I. Exitos y fracasos en endodoncia. Rev Asoc Odontol Argent, Buenos Aires, v. 50, n. 2, p. 67-74, Feb. 1962. 
KANTZ, W. E.; FERRILLO, P. J.; ZIMMERMANN, E. R. Cytotoxicity of three endodontic intracanal medicaments. Oral Surg Oral Med Oral Pathol, St. Louis, v. 38, n. 4, p. 600-604, Oct. 1974.

KAPLOWITZ, G. J. Evaluation of gutta-percha solvents. J Endod, Chicago, v. 16 , n. 11 , p. 539-540, Nov. 1990.

KAUFMAN, D.; MOR, C.; STABHOLTZ, A.; ROTSTEIN, I. Effect of guttapercha solvents on calcium and phosphorus levels of cut human dentin. $\mathbf{J}$ Endod, Chicago, v. 23, n. 10, p. 614-615, Oct. 1997.

KAWAHARA, H.; YAMAGAMI, A.; NAKAMURA, M. Biological testing of dental materials by means of tissue culture. Int Dent J, London, v. 18, n. 2, p. 443-467, June 1968.

KAWAHARA, H.; IMAI, K.; KAWAHARA, D. Photo-pattern analysis and computation in the evaluation of the citotoxicity of dental materials in vitro. Int Dent J, London, v. 21, n. 2, p. 100-105, Marc. 1988.

KEREKES, K.; TRONSTAD, L. Long-term results of endodontic treatment performed with a standardized technique. J Endod, Chicago, v. 5, n. 3, p. 83-90, Mar. 1979. 
KETTERING, J. D.; TORABINEJAD, M. Cytotoxicity of root canal sealers: a study using HeLa cells and fibroblasts. Int Endod J, London, v. 17, n. 2, p. 60-66, Apr. 1984.

LADLEY, R. W.; CAMPBELL, A. D.; HICKS, M. L.; LI, S. H. Effectiveness of halothane used with ultrasonic or hand instrumentation to remove guttapercha from the root canal. J Endod, Chicago, v. 17, n. 5, p. 221-224, May 1991.

LOPES, H. P.; SIQUEIRA Jr., J. F. Endodontia- Biologia e técnicas. Rio de Janeiro: Medsi, 1999. 650 p.

LEIRSKAR, J.; HELGELAND, K. Mechanism of toxicity of dental materials. Int Endod J, London, v. 14, n. 1, p. 42-48, Jan. 1981.

LOVDAHL, P. E. Endodontic retreatment. Dent Clin North Am, Philadelphia, v. 36, n. 2, p. 473-490, Apr. 1992.

LU, D. P. Alternative method for removing gutta-percha from canals. $\mathbf{N} \mathbf{Y}$ State Dent J, New York, v. 60, n. 5, p. 31-33, May 1994.

LUEBKE, R. G.; GLICK, D. H.; INGLE, J. I. Indications and contraindications for endodontic surgery. Oral Surg Oral Med Oral Pathol, St. Louis, v. 18, n. 1, p. 97-113, July 1964. 
McDONALD, M. N.; VIRE, D. E. Chloroform in the endodontic operatory. J Endod, Chicago, v. 18, n. 6, p. 301-303, June 1992.

MALHEIROS, C. F. Avaliação comparativa da citotoxicidade in vitro de EDTA e ácido cítrico aplicados em fibroblastos cultivados. 2000. $98 \mathrm{f}$.

Dissertação (Mestrado em Endodontia) - Faculdade de Odontologia, Universidade de São Paulo, São Paulo.

MASILLAMONI, C. R. M.; KETTERING, J. D.; TORABINEJAD, M. The biocompatibility of some root canal medicaments and irrigants. Int Endod J, London, v. 14, n. 2, p. 115-120, May 1981.

MERYON, S. D. Quantitative enzyme spectroscopy in the assessment of cell damage in vitro. Int Dent J, London, v. 21, n. 2, p. 113-119, Marc. 1988.

MURPHY, W. M. The testing of endodontic materials in vitro. Int Dent $\mathbf{J}$, London, v. 21, n. 2, p. 170-171, Marc. 1988.

OYAMA, K. O. N.; SIQUEIRA, E. L.; SANTOS, M. Action of different solvents on the gutta-percha cones. ECLER Endod, São Paulo, v. 1, n. 3, sept. 1999. Disponível em:http://ecler.bvs.Br/scielo.php? script=sci_issues\&pid=1516-4055\&lng=en\&nrm=iso $>$.Acesso em: 17 fev. 2003. 
OYAMA, K. O. N.; SIQUEIRA, E. L.; SANTOS, M. In vitro study of solvent on the root canal retreatment. Braz Dent J, Ribeirão Preto, v. 13, n. 3, p. 208211, set./dez.. 2002.

PAIVA, J. G.; ANTONIAZZI, J. H. Endodontia: bases para a prática clínica. $2^{\mathrm{a}}$. ed. São Paulo: Artes Médicas, 1988. 886 p.

PASCON, E. A.; SPANGBERG, L. S. W. In vitro cytotoxicity of root canal filling materials: 1. Gutta-percha. J Endod, Chicago, v. 16, n. 9, p. 429-433, Sept. 1990.

PÉCORA, J. D.; SPANÓ, J. C. E.; BARBIN, E. L. In vitro study on softening of gutta-percha cones in endodontic retreatment. Braz Dent J, Ribeirão Preto, v. 4, n. 1, p. 43-47, jan./jul. 1993.

PÉCORA, J. D.; COSTA, W. F.; SANTOS FILHO, D.; SARTI, S. J. Apresentação de um óleo essencial obtido de citrus aurantium, eficaz na desintegração do cimento de óxido de zinco-eugenol do interior do canal radicular. Odonto, São Bernardo do Campo, v. 1, n. 5, p. 130-132, jan./fev. 1992.

ROTSTEIN, I.; COHENCA, N.; TEPEROVICH, E.; MOSHONOV, J.; MOR, C.; ROMAN, I.; GEDALIA, I. Effect of chloroform, xylene, and halothane on enamel and dentin microhardness of human teeth. Oral Surg Oral Med Oral Pathol, St. Louis, v. 87, n. 3, p. 366-368, Mar. 1999. 
SANTOS, E. M. Análise da citotoxicidade in vitro de fármacos utilizados na terapia endodôntica de dentes decíduos. Estudo comparativo da ação da pasta Guedes-Pinto, formocresol, glutaraldeído e ácido fosfórico sobre cultura de fibroblastos. 1998. 153 f. Dissertação (Mestrado em Patologia Bucal). Faculdade de Odontologia, Universidade de São Paulo, São Paulo.

SCELZA, M. F. Z.; DANIEL, R. L. D P.; SANTOS, E. M.; JAEGER, M. M. M. Cytotoxic effects of $10 \%$ citric acid and EDTA-T used as root canal irrigants: an in vitro analysis. J Endod, Chicago, v. 27, n. 12, p. 741-743, Dec. 2001.

SCHMALTZ, G. Agar overlay method. Int Dent J, London, v. 21, n. 2, p. 5966, Marc. 1988.

SCHMALTZ, G. Use of cell cultures for toxicity testing of dental materialsadvantages and limitations. J Dent, v. 22, Suppl 2, S6-S11. 1994

SPANGBERG, L. Biological effects of root canal filling materials. 3. Effect of Tween 80 on human cells. Odontol Revy, Lund, v. 20, n. 3, p. 283-287, 1969.

SPANGBERG, L. Biological effects of root canal filling materials. 4. Effect in vitro of solubilised root canal filling materials on HeLa cells. Odontol Revy, Lund, v. 20, n. 3, p. 289-299, 1969. 
SPANGBERG, L.; AL-NAZHAN, S. A. The radiochromium release method for evaluation of cytotoxicity in vitro. Int Endod J, London, v. 21, n. 2, p. 72 78, Mar. 1988.

SPANGBERG, L. ; CONN, F. Correlation of in vivo and in vitro screening tests. J Endod, Chicago, v. 4, n. 10, p. 296-299, Oct. 1978.

SPANGBERG, L.; CONN, F. Kinetic and quantitative evaluation of material cytotoxicity in vitro. Oral Surg Oral Med Oral Pathol, St. Louis, v. 35, n. 3, p. 389-401, Mar. 1973.

SPANGBERG, L.; LANGELAND, K. Biologic effects of dental materials. Oral Surg Oral Med Oral Pathol, St. Louis, v. 35, n. 3, p. 403-414, Mar. 1973.

SPANGBERG, L.; PASCON, E. A. The importance of material preparation for the expression of cytotoxicity during in vitro evaluation of biomaterials. $\mathbf{J}$ Endod, Chicago, v. 14, n. 5, p. 247-250, May 1988.

SPANÓ, J. C. E.; BARBIN, E. L.; BONINI, A.; PÉCORA, J. D. Eficácia dos óleos essenciais na desobturação dos canais radiculares. Robrac, Goiânia, v. 5 , n. 14 , p. 25-28, mar. 1995. 
STABHOLZ, A.;FRIEDMAN, S. Endodontic retreatment-case selection and technique. Part 2: treatment planning for retreatment. J Endod, Chicago, v.14, n. 12, p. 607-614, Dec. 1988.

TAINTOR, J. F.; INGLE, J. I.; FAHID, A. Retreatment versus further treatment. Clin Prev Dent, Philadelphia, v. 5, n. 5, p. 8-14, Sept./Oct. 1983.

TAMSE, A.; UNGER, U.; METZGER, Z.; ROSENBERG, M. Gutta-percha solvents-a comparative study. J Endod, Chicago, v. 12, n. 8, p. 337-339, Aug. 1986.

TEPLITSKY, P. E.; RAYNER, D.; CHIN, I.; MARKOWSKY, R. Gutta-percha removal utilizing GTX instrumentation. J Can Dent Assoc, Ottawa, v. 58, n. 1, p. 53-58, Jan. 1992.

THE CONDENSED CHEMICAL DICTIONARY. $6^{\text {th }}$ ed. New York: Reinhold Publishing Corporation, 1966. 1256 p.

THE MERCK INDEX an encyclopedia of chemicals, drugs, and biologicals. $11^{\text {st }}$, Centennial Edition, New Jersey: Merck \& Co. 1989.

TORKELSON, T. R.; OYEN, F.; ROWE, V. K. The toxicity of chloroform as determined by single and repeteated expose of laboratory animals. Am Ind Hyg Assoc J, Chicago , v. 37, n. 12, p. 697-705, Dec. 1976. 
TYAS, M. J. Quantitative enzyme cytochemistry in the in vitro biocompatibility testing of dental materials. Int Endod J, London, v. 21, n. 2, p. 106-112, Mar. 1988.

UEMURA, M.; HATA, G.; TODA, T.; WEINE, F. S. Effectiveness of eucalyptol and $d$-limonene as gutta-percha solvents. J Endod, Chicago, v. 23, n. 12, p. 739-747, Dec. 1997.

VANDER WALL, G. L.; DOWSON, J.; SHIPMAN Jr., C.; ARBOR, A. Antibacterial efficacy and cytotoxicity of three endodontic drugs. Oral Surg Oral Med Oral Pathol, St. Louis, v. 33, n. 2, p. 230-234, Feb. 1972.

WENNBERG, A. An in vitro method for toxicity evaluation of water-soluble substances. Acta Odont Scand, v. 34, n. 1, p. 33-41, Jan. 1976.

WENNBERG, A. In vitro assessment of the biocompatibility of dental materials-the Millipore filter method. Int Endod J, London, v. 21, n. 2, p. 6771, Mar. 1988.

WENNBERG, A.; ORSTAVIK, D. Evaluation of alternatives solvents to chloroform in endodontic practice. Endod Dent Traumatol, Copenhagen, v. 5, n. 5, p. 234-237, Oct. 1989. 
WILCOX, L. R. Endodontic retreatment with halothane versus chloroform solvent. J Endod, Chicago. v. 21, n. 6, p. 305-307, June 1995.

WILCOX, L. R.; KRELL, K. V.; MADISON, S.; RITTMAN, B. Endodontic retreatment: evaluation of gutta-percha and sealer removal and canal reinstrumentation. J Endod, Chicago. v. 13, n. 9, p. 453-457, Sept. 1987.

WOURMS, D. J.; CAMPBELL, A. D.; HICKS, L.; PELLEU, G. B. Alternative solvents to chloroform for gutta-percha. J Endod, Chicago v. 16, n. 5, p. 224226, May 1990.

ZAKARIASEN, K. L.; BRAYTON, S. M. COLLINSON, D. M. Efficient and effective root canal retreatment without chloroform. J Can Dent Assoc, Ottawa, v. 56, n. 6, p. 509-512, June 1990. 


\section{SUMMARY}

\section{COMPARATIVE EVALUATION IN VITROOF SOLVENTS CITOTOXICITY USED IN ENDODONTIC RETRATAMENT}

The aim of this study was to compare in vitro solvents used in endodontic retreatment therapy: orange oil, eucalyptol, xylene, chloroform and halothane through cytotoxicity evaluation of each solvent in different final concentration and contact conditions to NIH 3T3 fibroblasts cells lines. The experiment was divided in four stages: stage 1- the solvents were mixed in culture medium (DMEM) in final concentrations of $0,5,10,25,50$ and $100 \%$ placed on the cells in culture for periods of 5 minutes; stage 2- the solvents were mixed in culture medium in finals concentrations of 0,10 and $25 \%$ placed on the cells in culture for periods of 10 and 15 minutes; stage 3a- the solvents were placed on the fibroblasts cells (direct contact) and added culture medium; stage 3b- the fibroblasts cells get first culture medium and after that solvents were placed (indirect contact), in bouth the finals concentrations were 0,5 and $10 \%$ for periods of 5 minutes; stage 4 - solvents were previously solubilized in absolut alcohol in 1:1 proportion and mixed in culture medium in $5 \%$ final concentration for periods of 5 minutes. The evaluation were achieved by cellular counting through dyed exclusion method-Trypan blue. 
The results showed that all solvents were toxic in vitro, and orange oil was less toxic and it allowed some cellular viability. And we could observe that a previous solvents preparation influenced in the viable cells percentage. 


\section{AUTORIZAÇÃO}

Autorizo a reprodução e/ou divulgação total ou parcial da presente obra, por qualquer meio convencional ou eletrônico, desde que citada a fonte e comunicada, ao autor, a referência em que consta a citação.

Kazumi Onaga Nagayama Oyama

Assinatura

Instituição / Departamento: Faculdade de

Odontologia - Departamento de Dentística -

Disciplina de Endodontia

Local e data: São Paulo, março de 2003

Endereço: Av. Professor Lineu Prestes, 2227 -

Cidade Universitária - São Paulo - SP

E-mail:kazumioyama@usp.br 